\title{
Reactions of Titanium Imides and Hydrazides with Boranes
}

\author{
Simona Mellino, ${ }^{\dagger}$ Laura C. Stevenson, ${ }^{\dagger}$ Eric Clot, ${ }^{*}+\bullet$ and Philip Mountford ${ }^{*}{ }^{\dagger}$ \\ ${ }^{\dagger}$ Chemistry Research Laboratory, Department of Chemistry, University of Oxford, Mansfield Road, Oxford OX1 3TA, U.K. \\ ${ }^{\ddagger}$ Institut Charles Gerhardt Montpellier, UMR 5253 CNRS-UM-ENSCM, Université de Montpellier, cc 1501, Place Eugéne Bataillon, \\ F-34095 Montpellier Cedex 5, France
}

Supporting Information

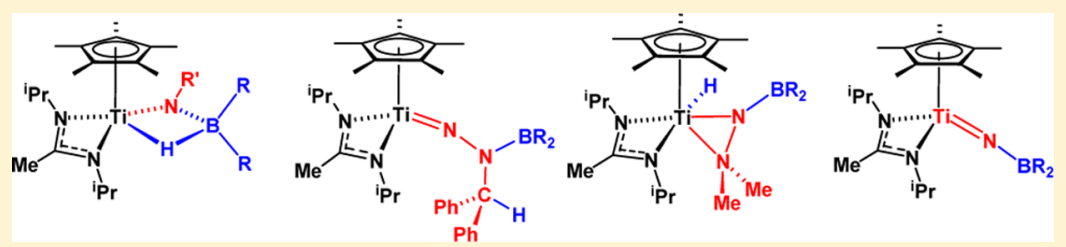

ABSTRACT: We report the first reactions of titanium imido, alkylidene hydrazido, and dimethylhydrazido compounds with the boranes $\mathrm{H}_{2} \mathrm{BTex}, 9-\mathrm{BBN}, \mathrm{HBAr}^{\mathrm{F}}{ }_{2}$, and HBPin $\left(\mathrm{Tex}=\right.$ tert-hexyl; $\left.\mathrm{Ar}^{\mathrm{F}}=\mathrm{C}_{6} \mathrm{~F}_{5}\right)$. Reactions of $\mathrm{Cp}{ }^{*} \mathrm{Ti}\left\{\mathrm{MeC}\left(\mathrm{N}^{\mathrm{i} P r}\right)_{2}\right\}(\mathrm{NTol})$ with $\mathrm{H}_{2} \mathrm{BTex}, 9-\mathrm{BBN}$, or $\mathrm{HBAr}_{2}^{\mathrm{F}}$ resulted in the hydride-bridged adducts $\mathrm{Cp} * \mathrm{Ti}\left\{\mathrm{MeC}\left(\mathrm{N}^{\mathrm{i}} \mathrm{Pr}_{2}\right)_{2}\right\}\left\{\mathrm{N}(\mathrm{Tol}) \mathrm{HBRR}^{\prime}\right\}$ without $\mathrm{B}-\mathrm{H}$ bond cleavage. $\mathrm{Cp}{ }^{*} \mathrm{Ti}\left\{\mathrm{MeC}\left(\mathrm{N}^{\mathrm{i}} \mathrm{Pr}\right)_{2}\right\}\left(\mathrm{NNCPh}_{2}\right)(4)$ reacted with $\mathrm{HBAr}_{2}{ }_{2}$ via a sequence of steps involving adducts at the $\beta$ - and then $\alpha$-nitrogen of the $\mathrm{NNCPh}_{2}$ ligand, before slow 1,2-addition of $\mathrm{B}-\mathrm{H}$ across the $\mathrm{N}=\mathrm{CPh}_{2}$ double bond of 4 , forming $\mathrm{Cp}{ }^{*} \mathrm{Ti}\left\{\mathrm{MeC}\left(\mathrm{N}^{\mathrm{i} P r}\right)_{2}\right\}\left\{\mathrm{NN}\left(\mathrm{BAr}_{2}^{\mathrm{F}}\right) \mathrm{CHPh}_{2}\right\}(\mathbf{1 7})$. The other boranes reacted immediately with 4 to form homologues of 17. These products are the first examples of borylhydrazido(2-) complexes. Reaction of $\mathrm{Cp} * \mathrm{Ti}\left\{\mathrm{MeC}\left(\mathrm{N}^{\mathrm{i}} \mathrm{Pr}_{2}\right)_{2}\right\}\left(\mathrm{NNMe}_{2}\right)(\mathbf{2})$ with $\operatorname{HBAr}^{\mathrm{F}}{ }_{2}$ gave the hydride-bridged adduct $\mathrm{Cp} * \mathrm{Ti}\left\{\mathrm{MeC}\left(\mathrm{N}^{\mathrm{i}} \mathrm{Pr}_{2}\right)_{2}\right\}\left\{\mathrm{N}\left(\mathrm{NMe}_{2}\right) \mathrm{HBAr}_{2}{ }_{2}\right\}$, whereas with HBPin B-H bond cleavage occurred to form the borylhydrazide(1-)-hydride $\mathrm{Cp} * \mathrm{Ti}\left\{\mathrm{MeC}\left(\mathrm{N}^{i} \mathrm{Pr}\right)_{2}\right\}(\mathrm{H})\left\{\mathrm{N}(\mathrm{BPin}) \mathrm{NMe}_{2}\right\}$. Finally, reaction of 2 with 9-BBN dimer resulted in $\mathrm{H}_{2}$ elimination and formation of $\mathrm{Me}_{2} \mathrm{NBC}_{8} \mathrm{H}_{14}$ and $\mathrm{Cp}{ }^{*} \mathrm{Ti}\left\{\mathrm{MeC}\left(\mathrm{N}^{\mathrm{i}} \mathrm{Pr}\right)_{2}\right\}\left(\mathrm{NBC}_{8} \mathrm{H}_{14}\right)$, a rare example of a borylimido compound.

\section{INTRODUCTION}

A series of reviews and recent papers have charted the remarkable developments in Group 4 imido (L)M(NR), hydrazido ( $\mathrm{L}) \mathrm{M}\left(\mathrm{NNR}_{2}\right){ }^{2}$ and alkylidene hydrazido/diazoalkane (L)M( $\left.\mathrm{NNCR}_{2}\right)^{3}$ compounds over the last ca. 25 years ( $\mathrm{L}$ = supporting ligand set; $\mathrm{R}=\mathrm{H}$ or hydrocarbyl). Other classes of Group 4 imido-type compounds featuring heteroatom substituents have also been recently reported, namely the titanium tert-butoxyimides ( $\mathrm{L}) \mathrm{Ti}\left(\mathrm{NO}^{\mathrm{t}} \mathrm{Bu}\right)^{4}$ and borylimides $(\mathrm{L}) \mathrm{Ti}\left(\mathrm{NBR}_{2}\right){ }^{5}$ In general, the dominant feature of these compounds is their addition or insertion reactions with unsaturated compounds at the $\mathrm{M}-\mathrm{N}_{\alpha}$ multiple bond itself (best described as a $\sigma^{2} \pi^{4}$ triple bond). For certain hydrazido, ${ }^{6}$ alkylidene hydrazido, ${ }^{3 c}$ and tert-butoxyimido ${ }^{4 a, c}$ compounds, reductive cleavage of the $\mathrm{N}_{\alpha}-\mathrm{N}_{\beta}$ or $\mathrm{N}_{\alpha}-\mathrm{O}_{\beta}$ bond can occur with reducing substrates such as $\mathrm{CO}$, isonitriles, and alkynes. Less commonly, dating from Bergman and Wolczanski's first reports on these compounds, ${ }^{7}$ Group 4 imides can also activate the $\mathrm{C}-\mathrm{H}$ bonds of organic substrates, and also the $\mathrm{H}-\mathrm{H}$ bond of $\mathrm{H}_{2}$. As documented in the reviews, ${ }^{1 \mathrm{a}-c, \mathrm{e}, \mathrm{g}}$ many significant advances regarding these aspects have been achieved. ${ }^{3 \mathrm{~d}, 8}$

In contrast, $\mathrm{Si}-\mathrm{H}$ and, especially, $\mathrm{B}-\mathrm{H}$ bond activation reactions of Group 4 imido and hydrazido-type compounds with silanes and boranes are still poorly developed, although they are better known for transition metal-heteroatom multiple bonds in general. ${ }^{9}$ There are no reported $\mathrm{Si}-\mathrm{H}$ additions to Group 4 imides. In related chemistry, Si-H 1,2- addition to the $\mathrm{Ti}-\mathrm{S}$ bond of $\mathrm{Cp} *{ }_{2} \mathrm{Ti}(\mathrm{S})(\mathrm{py})$ and to a strained tantalum imide was reported some time ago. ${ }^{9 c, d}$ Very recently a scandium imide was shown to activate $\mathrm{Si}-\mathrm{H}$ bonds by 1,2addition to $\mathrm{Sc}-\mathrm{N}_{\alpha}$, albeit in a reversible equilibrium. ${ }^{9 \mathrm{e}}$

The situation with hydrazides and alkylidene hydrazides is better established, at least for titanium. Andersen and Bergman found that $\mathrm{Cp}_{2}{ }_{2} \mathrm{Ti}\left(\eta^{2}-\mathrm{NNCHTol}\right)$ reacted with $\mathrm{PhSiH}_{3}$ or $\mathrm{Ph}_{2} \mathrm{SiH}_{2}$ by 1,2 -addition to $\mathrm{Ti}-\mathrm{N}_{\alpha}$ forming alkylidene hydrazide(1-)-hydride products, $\mathbf{1}$, as illustrated in Figure $1 .^{3 c}$ We subsequently reported that the dimethylhydrazide $\mathrm{Cp}^{*} \mathrm{Ti}-$ $\left\{\mathrm{MeC}\left(\mathrm{N}^{\mathrm{i} P r}\right)_{2}\right\}\left(\mathrm{NNMe}_{2}\right)$ (2) forms analogous 1,2-addition products, 3 (Figure 1), with primary aryl silanes $\mathrm{ArSiH}_{3}$ or $\mathrm{BuSiH}_{3}$ in a reversible equilibrium. ${ }^{10}$ No reaction occurred with the diphenylhydrazido or imido counterparts of 2 . DFT calculations found that, without additional coordination of the $\beta$ - $\mathrm{NMe}_{2}$ group in $3,1,2$-addition to $\mathrm{Ti}-\mathrm{N}_{\alpha}$ was thermodynamically unfavorable. The alkylidene hydrazide analogue of 2, $\mathrm{Cp}{ }^{*} \mathrm{Ti}\left\{\mathrm{MeC}\left(\mathrm{N}^{\mathrm{i}} \mathrm{Pr}\right)_{2}\right\}\left(\mathrm{NNCPh}_{2}\right)$ (4), also reacted with $\mathrm{ArSiH}_{3}$ or $\mathrm{Ph}_{2} \mathrm{SiH}_{2}$, forming $\mathrm{N}, \mathrm{N}^{\prime}$-disubstituted hydrazide(2-) products 5 , featuring net $1,3 \mathrm{Si}-\mathrm{H}$ bond addition across the $\mathrm{N}-\mathrm{N}=\mathrm{CPh}_{2}$ moiety of $4 .^{3 \mathrm{e}}$ Mechanistically, this proceeds via 1,2-addition of $\mathrm{Si}-\mathrm{H}$ to $\mathrm{Ti}-\mathrm{N}_{\alpha}$ to give a hydrazide(1-)-hydride intermediate, analogous to $\mathbf{1}$ and 3,

Received: June 23, 2017

Published: August 22, 2017 
<smiles></smiles>

1

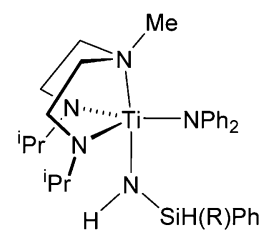

6

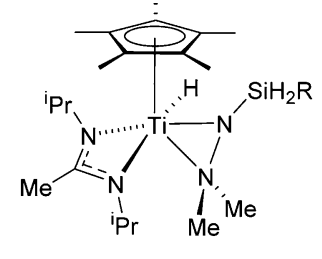

3

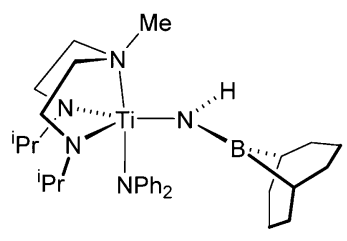

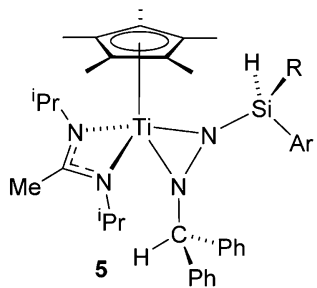

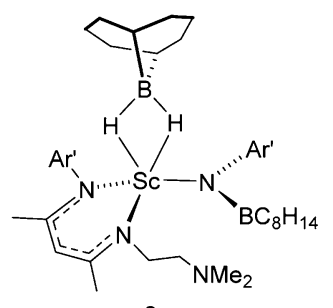

8

Figure 1. Examples of products of $\mathrm{Si}-\mathrm{H}$ or $\mathrm{B}-\mathrm{H}$ bond activation with imido and hydrazido compounds $\left(\mathrm{Ar}^{\prime}=2,6-\mathrm{C}_{6} \mathrm{H}_{3}{ }^{\mathrm{i}} \mathrm{Pr}_{2}\right){ }^{3 c, e, 5 b, 9 f, 10}$

followed by hydride migration to the electrophilic $\mathrm{N}_{\beta} \underline{\mathrm{CPh}}$ carbon.

Very recently we also reported the reductive $\mathrm{N}_{\alpha}-\mathrm{N}_{\beta}$ bond cleavage reactions of $\mathrm{Ti}\left(\mathrm{N}_{2} \mathrm{~N}^{\mathrm{Me}}\right)\left(\mathrm{NNPh}_{2}\right)\left(\right.$ py) with $\mathrm{PhSiH}_{3}$ and $\mathrm{Ph}_{2} \mathrm{SiH}_{2}{ }^{5 \mathrm{~b}} \mathrm{DFT}$ and kinetic studies found that this reaction proceeds via concerted $\mathrm{Si}-\mathrm{H}$ bond addition across the $\mathrm{Ti}-\mathrm{N}_{\alpha}$ bond to again form a hydrazide(1-)-hydride intermediate (cf. 1 and 3). Subsequent hydride migration to the $\mathrm{N}_{\alpha}$ atom of the soformed $\eta^{2}-\mathrm{N}\left(\mathrm{SiH}_{2} \mathrm{R}\right) \mathrm{NPh}_{2}$ ligand is coupled with $\mathrm{N}_{\alpha}-\mathrm{N}_{\beta}$ bond cleavage, forming 6 (Figure 1). Furthermore, reaction of $\mathrm{Ti}\left(\mathrm{N}_{2} \mathrm{~N}^{\mathrm{Me}}\right)\left(\mathrm{NNPh}_{2}\right)(\mathrm{py})$ with 9-BBN $\left(\left[(\mu-\mathrm{H}) \mathrm{BC}_{8} \mathrm{H}_{14}\right]_{2}\right)$ formed the borylamide counterpart 7 , and DFT and kinetic studies established an analogous mechanism to that for $6{ }^{5 \mathrm{~b}, 11} \mathrm{~A}$ homologous compound to 6 was formed using $\mathrm{HBMes}_{2}$ (Mes $=2,4,6-\mathrm{C}_{6} \mathrm{H}_{2} \mathrm{Me}_{3}$ ), but with pinacol borane (HBPin) or Piers' borane $^{12}\left(\mathrm{HAr}^{\mathrm{F}}{ }_{2}, \mathrm{Ar}^{\mathrm{F}}=\mathrm{C}_{6} \mathrm{~F}_{5}\right)$ mixtures or undesired products of ligand transmetalation were obtained. ${ }^{11}$

The $\mathrm{N}_{\alpha}-\mathrm{N}_{\beta}$ bond cleavage processes leading to 6 and 7 were the first of their type with silanes or boranes. More generally, the reactions of $\mathrm{Ti}\left(\mathrm{N}_{2} \mathrm{~N}^{\mathrm{Me}}\right)\left(\mathrm{NNPh}_{2}\right)$ (py) with $\mathrm{HBR}_{2}$ were the first $\mathrm{B}-\mathrm{H}$ activation reactions reported for any metal hydrazide. Furthermore, the first $\mathrm{B}-\mathrm{H}$ activation reaction of an imide was described only recently by Chen for a scandium compound reacting with 9-BBN, forming 8 (Figure 1). ${ }^{9 f}$ Subsequently Walter et al. reported the first $\mathrm{B}-\mathrm{H} \mathrm{1,2-addition} \mathrm{reaction} \mathrm{of} \mathrm{an}$ actinide imide for $\left(\eta-\mathrm{C}_{5} \mathrm{H}_{2}{ }^{\mathrm{t}} \mathrm{Bu}_{3}\right)_{2} \mathrm{Th}(\mathrm{NTol})\left(\mathrm{Tol}=4-\mathrm{C}_{6} \mathrm{H}_{4} \mathrm{Me}\right)$ with $9-\mathrm{BBN} .^{13}$ No well-defined reactions of Group 4 imides with the $\mathrm{B}-\mathrm{H}$ bonds of boranes have so far been reported. However, Lancaster recently showed that reaction of $\mathrm{Cp}_{2} \mathrm{HfCl}_{2}$ with 2 equiv of the lithiated borylamide $\mathrm{LiNH}_{2} \mathrm{BHAr}_{2}{ }_{2}$ formed $\mathrm{Cp}_{2} \mathrm{Hf}\left\{\mathrm{N}(\mathrm{H}) \mathrm{HBAr}^{\mathrm{F}}{ }_{2}\right\}(9)$ as one component of a mixture, with the overall elimination of $\mathrm{H}_{3} \mathrm{NBHAr}^{\mathrm{F}}{ }_{2}$ and $\mathrm{LiCl}^{14}$ Although 9 appears formally to be the product of the 1,2-addition of $\mathrm{HBAr}_{2}{ }_{2}$ to the $\mathrm{Hf}-\mathrm{N}_{\alpha}$ bond of $\mathrm{Cp}_{2} \mathrm{Hf}(\mathrm{NH}$ ) (not known as an isolated species), the mechanism of its formation is unclear and probably proceeds via an amidohydroborate intermediate that is subsequently dehydrohalogenated by additional $\mathrm{LiNH}_{2} \mathrm{BHAr}_{2}{ }_{2}$.

Overall, the $\mathrm{B}-\mathrm{H}$ bond activation reactions of Group 4 imides and hydrazides/alkylidene hydrazides have not been developed in any detail, although there are encouraging and interesting precedents as outlined above. In this contribution we report the reactions of titanium compounds of this type

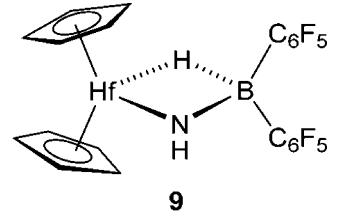

with different types of primary and secondary boranes. A part of this work has been reported in a preliminary communication. ${ }^{5 \mathrm{~b}}$

\section{RESULTS AND DISCUSSION}

As described in the Introduction, we found previously that titanium half-sandwich amidinate compounds of the type $\mathrm{Cp}^{*} \mathrm{Ti}\left\{\mathrm{MeC}\left(\mathrm{N}^{\mathrm{i} P r}\right)_{2}\right\}(\mathrm{NR})\left(\mathrm{R}=\right.$ hydrocarbyl, $\mathrm{NCPh}_{2}$ or $\mathrm{NR}_{2}^{\prime}$ ) provided good starting points for developing $\mathrm{Si}-\mathrm{H}$ bond activation chemistry of imido and hydrazido compounds. ${ }^{3 e, 10}$ We therefore used this class of compound for our current study with boranes. Preliminary screening with several borane types (vide infra) established that the tolylimide $\mathrm{Cp} * \mathrm{Ti}\{\mathrm{MeC}$ $\left.\left(\mathrm{N}^{\mathrm{i}} \mathrm{Pr}\right)_{2}\right\}(\mathrm{NTol})(\mathbf{1 0})$, alkylidene hydrazide $\mathrm{Cp} * \mathrm{Ti}\{\mathrm{MeC}-$ $\left.\left(\mathrm{N}^{\mathrm{i}} \mathrm{Pr}\right)_{2}\right\}\left(\mathrm{NNCPh}_{2}\right)(4)$, and dimethylhydrazide $\mathrm{Cp} * \mathrm{Ti}\{\mathrm{MeC}$ $\left.\left(\mathrm{N}^{\mathrm{i}} \mathrm{Pr}\right)_{2}\right\}\left(\mathrm{NNMe}_{2}\right)$ (2) (Figure 2) gave the best outcomes in terms of reactivity and product isolation. For example, the tertbutylimide $\mathrm{Cp} * \mathrm{Ti}\left\{\mathrm{MeC}\left(\mathrm{N}^{\mathrm{i}} \mathrm{Pr}\right)_{2}\right\}\left(\mathrm{N}^{\mathrm{t}} \mathrm{Bu}\right)$ did not react with boranes, and the diphenylhydrazide $\mathrm{Cp} \mathrm{p}^{*} \mathrm{Ti}\left\{\mathrm{MeC}\left(\mathrm{N}^{\mathrm{i}} \mathrm{Pr}\right)_{2}\right\}$ $\left(\mathrm{NNPh}_{2}\right)$ reacted only with 9-BBN, under forcing conditions as discussed later on. In a similar way, we screened a number of

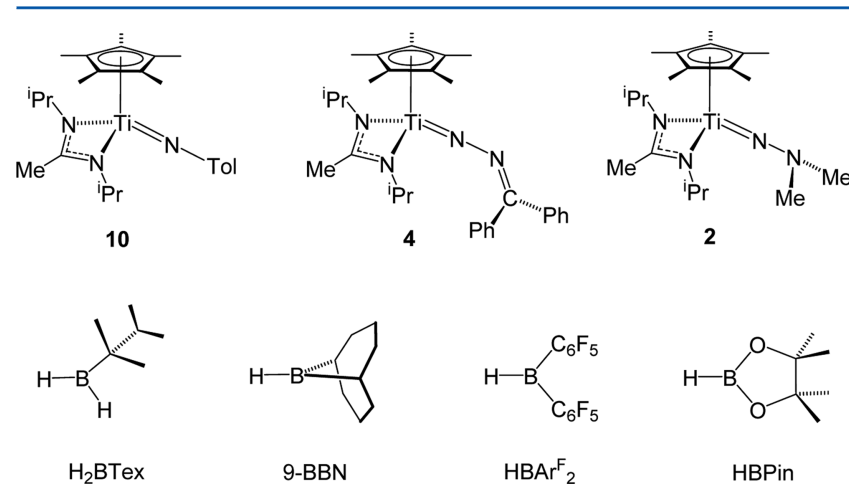

Figure 2. Principal titanium compounds and hydroboranes (shown in their monomeric form) used in this study. 
hydroboranes possessing different substitution patterns at boron. The successful candidate boranes carried forward from these trials are listed in Figure 2 and represent primary $\left(\mathrm{H}_{2} \mathrm{BTex}, \mathrm{Tex}=\text { tert-hexyl }\right)^{15}$ and secondary boranes. Among the latter set there are electron-poor $\left(\operatorname{HBAr}^{\mathrm{F}}{ }_{2}\right),{ }^{12}$ dialkyl (9BBN), and electron-rich (HBPin) homologues. Among other boranes assessed were $\mathrm{HBCy}_{2},{ }^{16} \mathrm{HBMes}_{2},{ }^{19} \mathrm{HB}\left(\mathrm{NAr}{ }^{\prime} \mathrm{CH}\right)_{2}{ }^{18}$ $\left.\mathrm{HB}\left(\mathrm{N}^{\mathrm{i} P r C H}\right)_{2}\right)^{19}$ and HBCat $\left(\mathrm{Cat}=1,2-\mathrm{O}_{2} \mathrm{C}_{6} \mathrm{H}_{4}\right)$. These either gave nonisolable equilibrium mixtures, poorly defined products, or no reaction at all. In addition we also carried out reactions of the tert-butoxyimide $\mathrm{Cp} * \mathrm{Ti}\left\{\mathrm{MeC}\left(\mathrm{N}^{\mathrm{i}} \mathrm{Pr}\right)_{2}\right\}$ $\left(\mathrm{NO}^{\mathrm{t}} \mathrm{Bu}\right.$ ) (known to undergo $\mathrm{Ti}-\mathrm{N}_{\alpha}$ addition or $\mathrm{N}_{\alpha}-\mathrm{O}_{\beta}$ cleavage reactions with unsaturated substrates ${ }^{4}$ ) with boranes and silanes. Unfortunately complexes of unknown mixtures were invariably formed in this case.

Reactions of $\mathrm{Cp} * \mathrm{Ti}\left\{\mathrm{MeC}\left(\mathrm{N}^{\mathrm{P} P r}\right)_{2}\right\}$ (NTol) (10) with boranes. Initial NMR tube scale reactions of 10 with $\mathrm{H}_{2} \mathrm{BTex}$ or $\mathrm{HBAr}^{\mathrm{F}}{ }_{2}$ proceeded cleanly to completion over several hours to form Cp*Ti $\left\{\mathrm{MeC}\left(\mathrm{N}^{\mathrm{i}} \mathrm{Pr}_{2}\right)_{2}\right\}\left\{\mathrm{N}(\mathrm{Tol}) \mathrm{H}_{2} \mathrm{BTex}\right\}(\mathbf{1 1})$ and $\mathrm{Cp}^{*} \mathrm{Ti}-$ $\left\{\mathrm{MeC}\left(\mathrm{N}^{\mathrm{i}} \mathrm{Pr}_{2}\right)_{2}\right\}\left\{\mathrm{N}(\mathrm{Tol}) \mathrm{HBAr}_{2}^{\mathrm{F}}\right\} \quad$ (12) as summarized in Scheme 1. On the preparative scale, the new compounds

Scheme 1. Reactions of $\mathrm{Cp} * \mathrm{Ti}\left\{\mathrm{MeC}\left(\mathrm{N}^{\mathrm{i} P r}\right)_{2}\right\}(\mathrm{NTol})$ (10) with Boranes (shown in their monomeric forms)

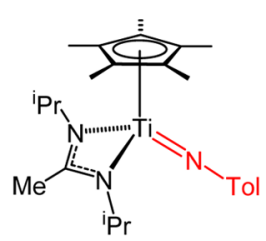

10
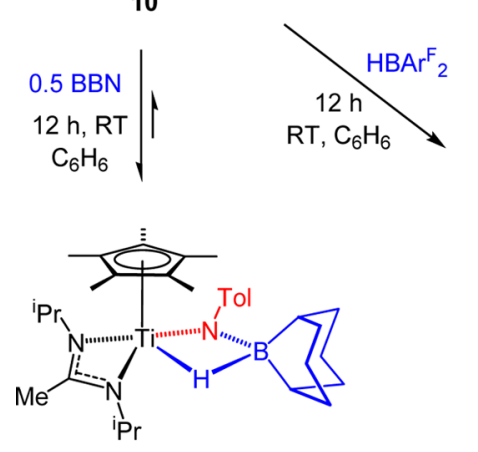

13

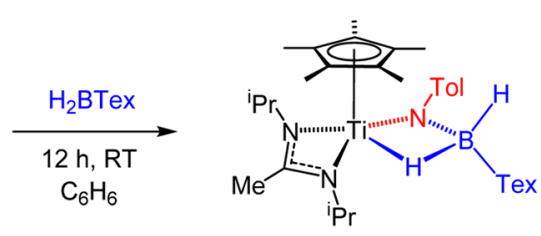

11

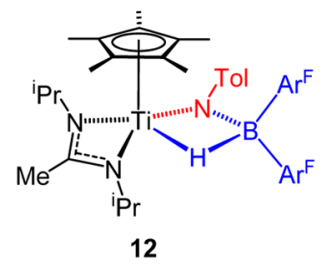

were isolated as yellow/brown powders in 60-75\% yield after workup. The reaction of 10 with $9-\mathrm{BBN}$ is discussed below, and no reaction occurred between 10 and HBPin.

The NMR spectra of $\mathbf{1 1}$ and $\mathbf{1 2}$ are consistent with the structures illustrated, and in particular their ${ }^{11} \mathrm{~B}$ NMR chemical shifts of 1.5 and $-7.7 \mathrm{ppm}$, respectively, are consistent with four-coordinate boron environments. ${ }^{20}$ The infrared spectrum of 11 showed two $\nu(\mathrm{B}-\mathrm{H})$ bands as expected: one at 2327 $\mathrm{cm}^{-1}$ for the terminal $\mathrm{B}-\mathrm{H}$ unit and one at $1908 \mathrm{~cm}^{-1}$ for the $\mathrm{B}-\mathrm{H}$ bridging to titanium. For 12 , this $\nu(\mathrm{B}-\mathrm{H})_{\mathrm{b}}$ mode appears at a slightly higher frequency $\left(1939 \mathrm{~cm}^{-1}\right)$ suggesting a slightly stronger interaction of the hydride with boron as compared to 11. Diffraction-quality crystals of 11 and 12 were grown from pentane. The solid state structures are shown in Figure 3; selected bond lengths and angles are listed in Table 1.

Compounds 11 and 12 each have 4-legged piano stool geometries. The $\mathrm{Ti}-\mathrm{N}(2,3)$ and $\mathrm{Ti}-\mathrm{Cp}^{*}$ distances and associated angles for the supporting ligand sets are comparable and within the expected ranges. ${ }^{21}$ The $\operatorname{Ti}(1)-\mathrm{N}(1)$ bond distances are very similar, and their average value of $1.877(1) \AA$ is significantly lengthened compared to the typical values of 1.71-1.73 $\AA$ found in analogues of $\mathbf{1 0}$ (the X-ray structure of 10 itself has not been determined $)^{22}$ but somewhat shorter than the $\mathrm{Ti}-\mathrm{N}$ distances typically found for titanium amido compounds in general (ca. 1.93-2.03 $\AA$ ) and for $[2+2]$ cycloaddition products of titanium arylimides (ca. 1.94-2.04 $\AA) .{ }^{21}$ The $\mathrm{N}(1)-\mathrm{B}(1)$ distances (av. 1.544(2) $\AA$ ) in 11 and 12 are also comparable to each other and are in the range found for amidohydroborate complexes $\left(\left[\kappa^{2}-\mathrm{H}_{2} \mathrm{RBNR}_{2}\right]^{-}\right.$ligands, typically ca. $1.52-1.56 \AA$ ), known for a range of metals. ${ }^{21}$ The $\mathrm{N}(1)-\mathrm{B}(1)$ distance of $1.5426(14) \AA$ in 12 can also be compared with the corresponding value of $1.509(10) \AA$ in Lancaster's $\mathrm{Cp}_{2} \mathrm{Hf}\left\{\mathrm{N}(\mathrm{H}) \mathrm{HBAr}^{\mathrm{F}}{ }_{2}\right\}$ (9). The longer distance in 12 is attributed to the increased steric pressure at $\mathrm{N}_{\alpha}$ from the tolyl group. The ${ }^{11} \mathrm{~B}$ NMR chemical shift of $-7.7 \mathrm{ppm}$ in $\mathbf{1 2}$ is less negative than in $9(\delta=-27.5 \mathrm{ppm})$, consistent with a better developed $\mathrm{N}-\mathrm{B}$ interaction in the latter case.

The B-bound $\mathrm{H}$ atoms in $\mathbf{1 1}$ and $\mathbf{1 2}$ were located in the respective Fourier difference maps and were positionally and isotropically refined. The $\mathrm{Ti}(1)-\mathrm{H}(1)$ distances of 1.914(13) and 2.009(13) are significantly longer than in terminal titanium $(+4)$ hydrides in general (av. $1.66 \AA$, range 1.55$1.85 \AA$ for nine compounds in the current Cambridge Crystallographic Database $\left.{ }^{21}\right)$, and in the more closely related compounds 3 (Figure 1, av. $1.61 \AA$ ). The $\mathrm{Ti}(1)-\mathrm{H}(1)$ bond in 12 is longer $(\Delta(\mathrm{Ti}-\mathrm{H})=0.10(2) \AA)$ than in 11 , and its $\mathrm{B}(1)-$ $\mathrm{H}(1)$ is apparently shorter $(\Delta=0.05(2) \AA)$. This is attributed to the electron-withdrawing nature of the $\mathrm{C}_{6} \mathrm{~F}_{5}$ groups, which render the boron atom more Lewis acidic, despite the greater steric crowding in 12. The DFT structures (B3PW91 including corrections for dispersion and solvent effects, see the Experimental Section) have been calculated for $\mathbf{1 1}$ and $\mathbf{1 2}$. The DFT structure of $\mathbf{1 1}$ is shown in Figure 4, and key selected distances for 11 and 12 are given in the caption. The DFT structures confirm the key features of the X-ray structures and are discussed in further detail below.

Reaction of $\mathrm{Cp}^{*} \mathrm{Ti}\left\{\mathrm{MeC}\left(\mathrm{N}^{\mathrm{i} P P_{2}}\right)_{2}\right\}(\mathrm{NTol})$ (10) with 0.5 equiv of 9-BBN dimer formed $\mathrm{Cp} * \mathrm{Ti}\left\{\mathrm{MeC}\left(\mathrm{N}^{\mathrm{i}} \mathrm{Pr}_{2}\right)_{2}\right\}\{\mathrm{N}(\mathrm{Tol})$ $\left.\mathrm{HBC}_{8} \mathrm{H}_{14}\right\}$ (13) which was isolated as a viscous oil on workup. The NMR and IR spectra of 13 are consistent with the structure shown in Scheme 1 which is analogous to those of $\mathbf{1 1}$ and 12. The ${ }^{11} \mathrm{~B}$ NMR resonance in $\mathbf{1 3}$ appears at $10.4 \mathrm{ppm}$, consistent with a four-coordinate boron ${ }^{20}$ (note that the ${ }^{11} \mathrm{~B}$ resonance in 7 (Figure 1) appears at $54.4 \mathrm{ppm}$ for threecoordinate boron $\left.{ }^{\mathrm{Sb}}\right)$. The IR spectrum of 13 features a $\nu(\mathrm{B}-$ $\mathrm{H})_{\mathrm{t}}$ band at $1651 \mathrm{~cm}^{-1}$. Even though this value is comparatively low, it is nonetheless at a significantly higher frequency than for $\nu(\mathrm{Ti}-\mathrm{H})$ in the silylhydrazide(1-)-hydride compounds 3 $\left(1565-1585 \mathrm{~cm}^{-1}\right),{ }^{10 a}$ suggesting that an analogous borylamide-hydride product $\mathrm{Cp} * \mathrm{Ti}\left\{\mathrm{MeC}\left(\mathrm{N}^{\mathrm{i} P \mathrm{Pr}_{2}}\right)_{2}\right\}(\mathrm{H})\{\mathrm{N}(\mathrm{Tol})$ $\left.\mathrm{BC}_{8} \mathrm{H}_{14}\right\}$ has not been formed.

The DFT structure of $\mathbf{1 3}$ is shown in Figure 4 together with selected distances. The $\mathrm{Ti}-\mathrm{H}_{\mathrm{b}}$ and $\mathrm{B}-\mathrm{H}_{\mathrm{b}}$ distances are significantly shorter and longer, respectively, than in $\mathbf{1 1}$ and 12, showing a better-developed hydride transfer from boron to titanium, attributed to the more electron-releasing alkyl substituents in the case of 13. The computed $\nu(\mathrm{B}-\mathrm{H})_{\mathrm{b}}$ frequencies are $1891 \mathrm{~cm}^{-1}, 1939 \mathrm{~cm}^{-1}$, and $1755 \mathrm{~cm}^{-1}$ for 11, 12, and 13, respectively, in agreement with experimental trends. The calculated ${ }^{11} \mathrm{~B}$ NMR shifts are $2.0,-6.7$, and 8.0 

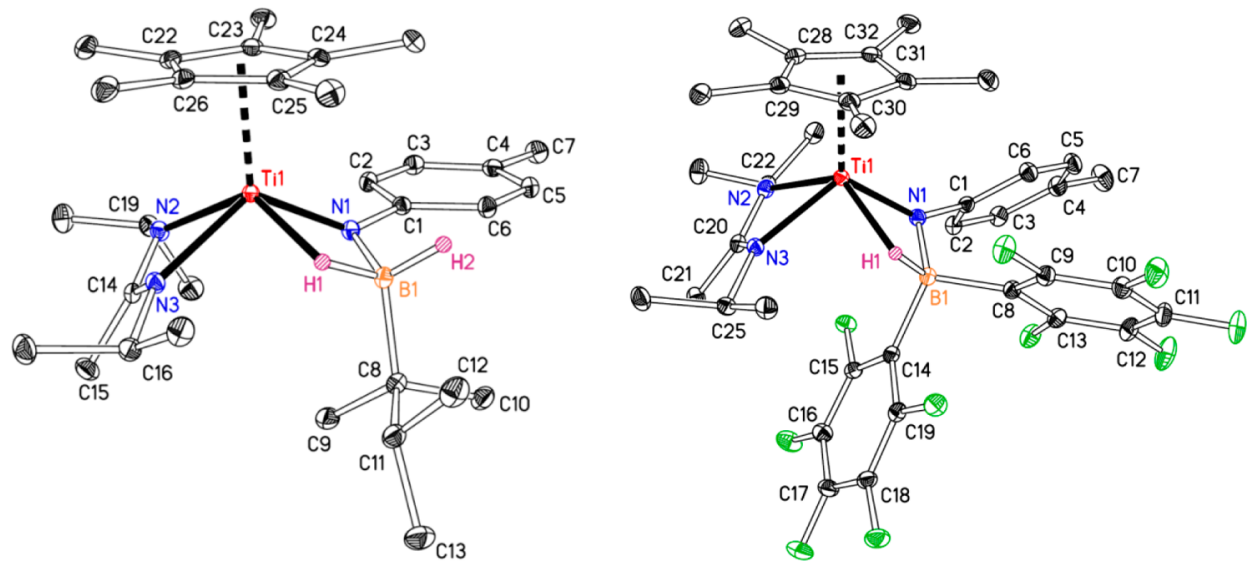

Figure 3. Displacement ellipsoid plots (25\% probability) of $\mathrm{Cp} * \mathrm{Ti}\left\{\mathrm{MeC}\left(\mathrm{N}^{\mathrm{i}} \mathrm{Pr}_{2}\right)_{2}\right\}\left\{\mathrm{N}(\mathrm{Tol}) \mathrm{H}_{2} \mathrm{BTex}\right\} \quad(\mathbf{1 1}$, left $)$ and $\mathrm{Cp} * \mathrm{Ti}\left\{\mathrm{MeC}\left(\mathrm{N}^{\mathrm{i}} \mathrm{Pr}\right)_{2}\right\}\{\mathrm{N}$ $\left.(\mathrm{Tol}) \mathrm{HBAr}_{2}{ }_{2}\right\}$ (12, right). C-bound $\mathrm{H}$ atoms are omitted for clarity. Remaining $\mathrm{H}$ atoms are drawn as spheres of an arbitrary radius.

Table 1. Selected Bond Distances $(\AA)$ and Angles (deg) for $\mathrm{Cp} * \mathrm{Ti}\left\{\mathrm{MeC}\left(\mathrm{N}^{\mathrm{i}} \mathrm{Pr}_{2}\right)_{2}\right\}\left\{\mathrm{N}(\mathrm{Tol}) \mathrm{H}_{2} \mathrm{BTex}\right\}(11)$ and $\mathrm{Cp}{ }^{*} \mathrm{Ti}\left\{\mathrm{MeC}\left(\mathrm{N}^{\mathrm{i}} \mathrm{Pr}_{2}\right)_{2}\right\}\left\{\mathrm{N}(\mathrm{Tol}) \mathrm{HBAr}_{2}{ }_{2}\right\}(12)^{a}$

\begin{tabular}{lll}
\multicolumn{1}{c}{ Parameter } & \multicolumn{1}{c}{$\mathbf{1 1}$} & \multicolumn{1}{c}{$\mathbf{1 2}$} \\
$\mathrm{Ti}(1)-\mathrm{C} \mathrm{p}_{\text {cent }}$ & 2.06 & 2.07 \\
$\mathrm{Ti}(1)-\mathrm{N}(1)$ & $1.8813(7)$ & $1.8725(9)$ \\
$\mathrm{Ti}(1)-\mathrm{N}(2)$ & $2.0817(7)$ & $2.0950(9)$ \\
$\mathrm{Ti}(1)-\mathrm{N}(3)$ & $2.1194(7)$ & $2.0910(8)$ \\
$\mathrm{Ti}(1)-\mathrm{H}(1)$ & $1.914(13)$ & $2.009(13)$ \\
$\mathrm{N}(1)-\mathrm{B}(1)$ & $1.5466(11)$ & $1.5426(14)$ \\
$\mathrm{B}(1)-\mathrm{H}(1)$ & $1.233(13)$ & $1.187(14)$ \\
$\mathrm{B}(1)-\mathrm{H}(2)$ & $1.131(13)$ & $\mathrm{n} . \mathrm{a}$. \\
$\mathrm{B}(1)-\mathrm{C}(8)$ & $1.6473(13)$ & $1.6296(14)$ \\
$\mathrm{C} \mathrm{p}_{\text {cent }}-\mathrm{Ti}(1)-\mathrm{N}(1)$ & 119.0 & 125.4 \\
$\mathrm{C} \mathrm{p}_{\text {cent }}-\mathrm{Ti}(1)-\mathrm{N}(2)$ & 114.5 & 114.0 \\
$\mathrm{C} \mathrm{p}_{\text {cent }}-\mathrm{Ti}(1)-\mathrm{N}(3)$ & 117.2 & 116.3 \\
$\mathrm{C} \mathrm{p}_{\text {cent }}-\mathrm{Ti}(1)-\mathrm{H}(1)$ & 111.6 & 111.8 \\
$\mathrm{~N}(1)-\mathrm{Ti}(1)-\mathrm{N}(2)$ & $103.69(3)$ & $99.94(4)$ \\
$\mathrm{Ti}(1)-\mathrm{N}(1)-\mathrm{B}(1)$ & $91.38(5)$ & $91.62(6)$ \\
$\mathrm{N}(1)-\mathrm{B}(1)-\mathrm{C}(8)$ & $117.54(7)$ & $113.69(8)$ \\
${ }^{\mathrm{N}} \mathrm{Not}$ applicable: $\mathrm{n} . \mathrm{a}$. & & \\
\hline
\end{tabular}

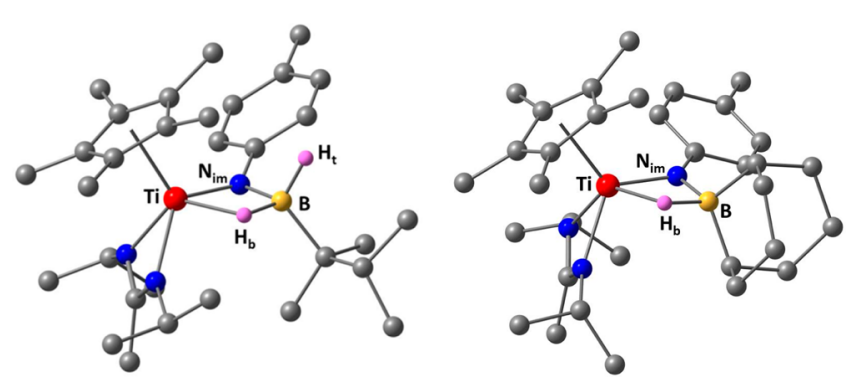

Figure 4. DFT structures of $\mathrm{Cp} * \mathrm{Ti}\left\{\mathrm{MeC}\left(\mathrm{N}^{\mathrm{i}} \mathrm{Pr}_{2}\right)_{2}\right\}\left\{\mathrm{N}(\mathrm{Tol}) \mathrm{H}_{2} \mathrm{BTex}\right\}$ (11, left) and $\mathrm{Cp} * \mathrm{Ti}\left\{\mathrm{MeC}\left(\mathrm{N}^{\mathrm{i}} \mathrm{Pr}_{2}\right)_{2}\right\}\left\{\mathrm{N}(\mathrm{Tol}) \mathrm{HBC}_{8} \mathrm{H}_{14}\right\}$ (13, right). C-bound $\mathrm{H}$ atoms omitted. Selected distances $(\AA)$ for $\mathrm{Cp} * \mathrm{Ti}\{\mathrm{MeC}$ $\left.\left(\mathrm{N}^{\mathrm{i}} \mathrm{Pr}_{2}\right)_{2}\right\}\left\{\mathrm{N}(\mathrm{Tol}) \mathrm{HBAr}_{2}^{\mathrm{F}}\right\}$ (12, not shown above): $\mathrm{Ti}-\mathrm{H}_{\mathrm{b}}$ 1.950, B$\mathrm{H}_{\mathrm{b}}$ 1.297, $\mathrm{Ti}-\mathrm{N}_{\mathrm{im}} 1.879, \mathrm{~B}-\mathrm{N}_{\mathrm{im}} 1.523$; for 11: $\mathrm{Ti}-\mathrm{H}_{\mathrm{b}} 1.904, \mathrm{~B}-\mathrm{H}_{\mathrm{b}}$ $1.309, \mathrm{~B}-\mathrm{H}_{\mathrm{t}} 1.231, \mathrm{Ti}-\mathrm{N}_{\mathrm{im}} 1.869, \mathrm{~B}-\mathrm{N}_{\mathrm{im}} 1.542$; for 13: $\mathrm{Ti}-\mathrm{H}_{\mathrm{b}} 1.853$, $\mathrm{B}-\mathrm{H}_{\mathrm{b}} 1.336, \mathrm{Ti}-\mathrm{N}_{\mathrm{im}} 1.853, \mathrm{~B}-\mathrm{N}_{\mathrm{im}} 1.541$.

ppm for 11, 12, and 13, respectively (experimental values: 1.4, -7.7 , and $10.4 \mathrm{ppm}$ ). In solution, 13 was found to partially dissociate to the starting imide and borane. A series of equilibrium constants were measured by NMR spectroscopy in
$\mathrm{C}_{7} \mathrm{D}_{8}$ (toluene- $d_{8}$ ) between 293 and $333 \mathrm{~K}$. The van't Hoff plot is shown in Figure 5, giving values of $\Delta_{\mathrm{r}} \mathrm{G}_{298}=-2.5(1)$ and $\Delta_{\mathrm{r}} \mathrm{H}=-9.5(2) \mathrm{kcal} \mathrm{mol}^{-1}$.

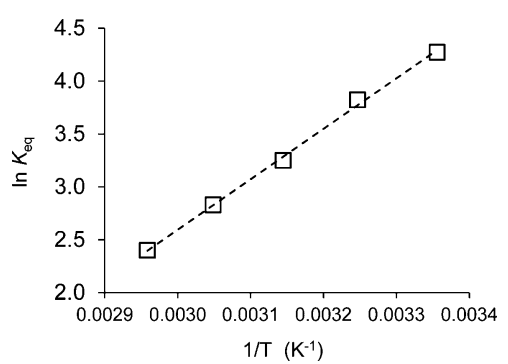

Figure 5. van't Hoff plot for the reaction $\mathrm{Cp} * \mathrm{Ti}\left\{\mathrm{MeC}\left(\mathrm{N}^{\mathrm{i} P r}\right)_{2}\right\}(\mathrm{NTol})$ $(10)+0.59-\mathrm{BBN}=\mathrm{Cp}{ }^{*} \mathrm{Ti}\left\{\mathrm{MeC}\left(\mathrm{N}^{\mathrm{i}} \mathrm{Pr}_{2}\right)_{2}\right\}\left\{\mathrm{N}(\mathrm{Tol}) \mathrm{HBC}_{8} \mathrm{H}_{14}\right\}$ (13). $\Delta_{\mathrm{r}} \mathrm{H}=-9.5(2) \mathrm{kcal} \mathrm{mol}^{-1}, \Delta_{\mathrm{r}} \mathrm{S}=-23.3(7) \mathrm{cal} \mathrm{mol}^{-1} \mathrm{~K}^{-1}, \Delta_{\mathrm{r}} \mathrm{G}_{298}=$ $-2.5(1) \mathrm{kcal} \mathrm{mol}^{-1}\left(R^{2}=0.998\right)$.

Table $S 1$ in the SI lists the computed $\Delta_{\mathrm{r}} \mathrm{G}_{298}$ values (kcal $\left.\mathrm{mol}^{-1}\right)$ for the formation of $11(-23.5), 12(-19.1)$, and 13 (0.8) from 10 and the respective dimeric boranes. These are consistent with only Cp* Ti $\left\{\mathrm{MeC}\left(\mathrm{N}^{\mathrm{i}} \mathrm{Pr}_{2}\right)_{2}\right\}\left\{\mathrm{N}(\mathrm{Tol}) \mathrm{HBC}_{8} \mathrm{H}_{14}\right\}$ (13) being involved in an equilibrium. The $\Delta_{\mathrm{r}} \mathrm{G}_{298}$ values starting from the monomeric boranes followed the same trend but were shifted to more negative values by $c a .-7$ to $-10 \mathrm{kcal}$ $\mathrm{mol}^{-1}$. Overall, 1,2-addition of $\mathrm{B}-\mathrm{H}$ to $\mathrm{Ti}-\mathrm{N}_{\mathrm{im}}$ with the primary borane $\mathrm{H}_{2} \mathrm{BTex}$ is slightly more thermodynamically favored than with the electron-deficient secondary borane, $\mathrm{HBAr}^{\mathrm{F}}{ }_{2}$; the bulkier and less Lewis acidic dialkyl borane $\mathrm{HBC}_{8} \mathrm{H}_{14}$ is by far the least favorable.

Reactions of $\mathrm{Cp} * \mathrm{Ti}\left\{\mathrm{MeC}\left(\mathrm{N}^{\mathrm{i} P r}\right)_{2}\right\}\left(\mathrm{NNCPh}_{2}\right)$ (4) with boranes. As mentioned in the Introduction (cf. Figure 1), reactions of alkylidene hydrazides with silanes have given either alkylidene hydrazide $(1-)$-hydride products (1, starting from $\left.\mathrm{Cp} *{ }_{2} \mathrm{Ti}\left(\eta^{2}-\mathrm{NNCHTol}\right)\right)$ or products of net $1,3 \mathrm{Si}-\mathrm{H}$ bond addition across the $\mathrm{N}-\mathrm{N}=\mathrm{CPh}_{2}$ moiety (5, starting from 4 ). This latter reaction is proposed to involve a transient hydride intermediate analogous to $\mathbf{1}$. Interestingly, the reactions of $\mathbf{4}$ with boranes (Scheme 2) formed three types of reaction product, or apparent intermediate, depending on the specific borane, but none of these is directly analogous to either $\mathbf{1}$ or $\mathbf{5}$.

Reaction of 4 with $\mathrm{H}_{2} \mathrm{BTex}, 9-\mathrm{BBN}$, or HBPin leads to a homologous series of products, $\mathrm{Cp} \mathrm{p}^{*} \mathrm{Ti}\left\{\mathrm{MeC}\left(\mathrm{N}^{\mathrm{i}} \mathrm{Pr}\right)_{2}\{\mathrm{NN}-\right.$ $\left.\left(\mathrm{BR}_{2}\right) \mathrm{CHPh}_{2}\right\}\left(\mathrm{BR}_{2}=\mathrm{BHTex}(14), \mathrm{BC}_{8} \mathrm{H}_{14}\right.$ (15), or BPin 
Scheme 2. Reactions of $\mathrm{Cp}{ }^{*} \mathrm{Ti}\left\{\mathrm{MeC}\left(\mathrm{N}^{\mathrm{i}} \mathrm{Pr}\right)_{2}\right\}\left(\mathrm{NNCPh}_{2}\right)$ (4) with Boranes (shown in their monomeric forms)

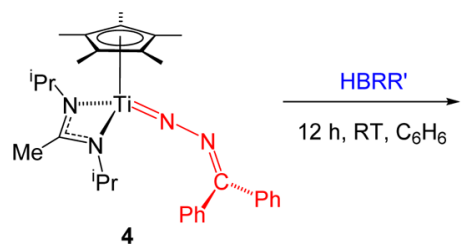

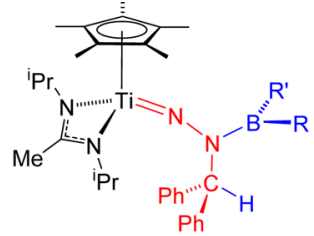

$B R R^{\prime}=B H T e x(14), \mathrm{BC}_{8} \mathrm{H}_{14}(15)$, BPin (16) or $\mathrm{Ar}_{2}$ (17)

$$
\begin{gathered}
\mathrm{HBArF}_{2} \\
\text { immediate } \\
\mathrm{C}_{6} \mathrm{H}_{6} \text { or } \\
\mathrm{C}_{6} \mathrm{D}_{6}
\end{gathered}
$$

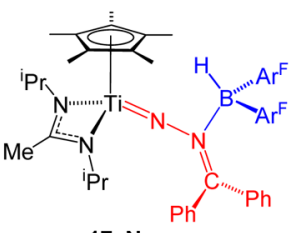

$17 \mathbf{N}_{\beta}$

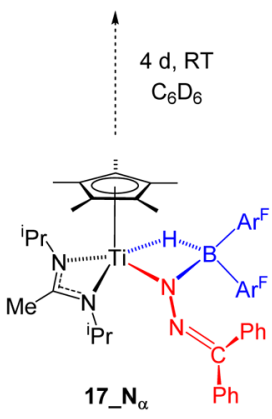

Table 2. Selected Bond Distances $(\AA)$ and Angles (deg) for $\mathrm{Cp} * \mathrm{Ti}\left\{\mathrm{MeC}\left(\mathrm{Ni}^{\mathrm{i} r}\right)_{2}\right\}\left\{\mathrm{NN}\left(\mathrm{BC}_{8} \mathrm{H}_{14}\right) \mathrm{CHPh}_{2}\right\}$ (15) and Cp*Ti $\left\{\mathrm{MeC}\left(\mathrm{N}^{\mathrm{i} P r}\right)_{2}\right\}\left\{\mathrm{NN}(\mathrm{BPin}) \mathrm{CHPh}_{2}\right\}(\mathbf{1 6})^{a}$

\begin{tabular}{lll}
\multicolumn{1}{c}{ Parameter } & \multicolumn{1}{c}{$\mathbf{1 5}$} & \multicolumn{1}{c}{$\mathbf{1 6}$} \\
$\mathrm{Ti}(1)-\mathrm{C} \mathrm{p}_{\text {cent }}$ & 2.08 & 2.08 \\
$\mathrm{Ti}(1)-\mathrm{N}(1)$ & $1.7256(16)$ & $1.7280(8)$ \\
$\mathrm{Ti}(1)-\mathrm{N}(3)$ & $2.1052(18)$ & $2.1071(8)$ \\
$\mathrm{Ti}(1)-\mathrm{N}(4)$ & $2.119(2)$ & $2.1243(8)$ \\
$\mathrm{N}(1)-\mathrm{N}(2)$ & $1.380(2)$ & $1.3723(11)$ \\
$\mathrm{N}(2)-\mathrm{B}(1)$ & $1.407(3)$ & $1.4186(13)$ \\
$\mathrm{B}(1)-\mathrm{O}(1)$ & n.a. & $1.3794(12)$ \\
$\mathrm{B}(1)-\mathrm{O}(2)$ & n.a. & $1.3798(12)$ \\
$\mathrm{B}(1)-\mathrm{C}(18)$ & $1.577(3)$ & n.a \\
$\mathrm{B}(1)-\mathrm{C}(14)$ & $1.583(3)$ & n.a. \\
$\mathrm{C} \mathrm{p}_{\text {cent }}-\mathrm{Ti}(1)-\mathrm{N}(1)$ & 124.9 & 124.8 \\
$\mathrm{C} \mathrm{p}_{\text {cent }}-\mathrm{Ti}(1)-\mathrm{N}(3)$ & 116.9 & 119.7 \\
$\mathrm{C} \mathrm{p}_{\text {cent }}-\mathrm{Ti}(1)-\mathrm{N}(4)$ & 117.2 & 121.5 \\
$\mathrm{Ti}(1)-\mathrm{N}(1)-\mathrm{N}(2)$ & $172.82(14)$ & $168.09(6)$ \\
$\mathrm{N}(1)-\mathrm{N}(2)-\mathrm{B}(1)$ & $122.67(16)$ & $119.69(8)$ \\
$\mathrm{N}(1)-\mathrm{N}(2)-\mathrm{C}(1)$ & $113.55(15)$ & $118.30(7)$ \\
$\mathrm{C}(1)-\mathrm{N}(2)-\mathrm{B}(1)$ & $123.44(16)$ & $119.69(8)$ \\
\hline
\end{tabular}

${ }^{a}$ Not applicable: n.a.

distance of $1.727(2) \AA$ is shorter compared to that of the starting $\mathrm{Cp}^{*} \mathrm{Ti}\left\{\mathrm{MeC}\left(\mathrm{N}^{\mathrm{i} P r}\right)_{2}\right\}\left(\mathrm{NNCPh}_{2}\right)(4)(1.751(2) \AA)$ and comparable to the $\mathrm{Ti}-\mathrm{N}_{\alpha}$ distances in the homologous hydrazides $\mathrm{Cp} * \mathrm{Ti}\left\{\mathrm{MeC}\left(\mathrm{N}^{\mathrm{i}} \mathrm{Pr}\right)_{2}\right\}\left(\mathrm{NNMe}_{2}\right) \quad(\mathbf{1 0}, 1.723(2) \AA)$ and $\mathrm{Cp} * \mathrm{Ti}\left\{\mathrm{MeC}\left(\mathrm{N}^{\mathrm{i}} \mathrm{Pr}\right)_{2}\right\}\left(\mathrm{NNPhR}^{\prime}\right)\left(\mathrm{R}^{\prime}=\mathrm{Me}\right.$ or $\mathrm{Ph}, 1.734(2)$ $\AA$ in both cases). ${ }^{23}$ The $\mathrm{N}(1)-\mathrm{N}(2)$ distances in $\mathbf{1 5}$ and $\mathbf{1 6}$ are the same within error, and comparable to those in $\mathrm{Cp} * \mathrm{Ti}$ $\left\{\mathrm{MeC}\left(\mathrm{N}^{\mathrm{i}} \mathrm{Pr}\right)_{2}\right\}\left(\mathrm{NNPhR}^{\prime}\right) \quad\left(\mathbf{1 0}\right.$ has a longer $\mathrm{N}_{\alpha}-\mathrm{N}_{\beta}$ bond because $\mathrm{N}_{\beta}$ is pyramidal). The sums of the $\mathrm{N}(1)-\mathrm{N}(2)-\mathrm{R}$ angles $\left(360.0(2)\right.$ and $\left.359.7(5)^{\circ}\right)$ establish a planar geometry at $\mathrm{N}(2)$, as is also found for $\mathrm{Cp}^{*} \mathrm{Ti}\left\{\mathrm{MeC}\left(\mathrm{N}^{\mathrm{i}} \mathrm{Pr}\right)_{2}\right\}\left(\mathrm{NNPhR}^{\prime}\right)$. The $\mathrm{N}(2)-\mathrm{B}(1)$ bond length in 16 is slightly longer $(\Delta=0.012(3)$ $\AA$ ) than in 15 because of competing $\pi$-donation from the Pin group $\mathrm{O}$ atoms. The other metric parameters for $\mathbf{1 5}$ and $\mathbf{1 6}$ are within the usual ranges and comparable to previous hydrazides $\mathrm{Cp} * \mathrm{Ti}\left\{\mathrm{MeC}\left(\mathrm{N}^{\mathrm{i}} \mathrm{Pr}\right)_{2}\right\}\left(\mathrm{NNRR}^{\prime}\right)$.

The reaction of 4 with $\mathrm{HBAr}_{2}{ }_{2}$ differs from those described above. When followed on the NMR tube scale, the immediately first-formed product is an adduct $\mathrm{Cp} * \mathrm{Ti}\left\{\mathrm{MeC}\left(\mathrm{N}^{\mathrm{i}} \mathrm{Pr}\right)_{2}\right\}\{\mathrm{NN}$ $\left.\left(\operatorname{HBAr}_{2}{ }_{2}\right) \mathrm{CPh}_{2}\right\}\left(17 \_\mathbf{N}_{\beta}\right)$ with the borane datively coordinated
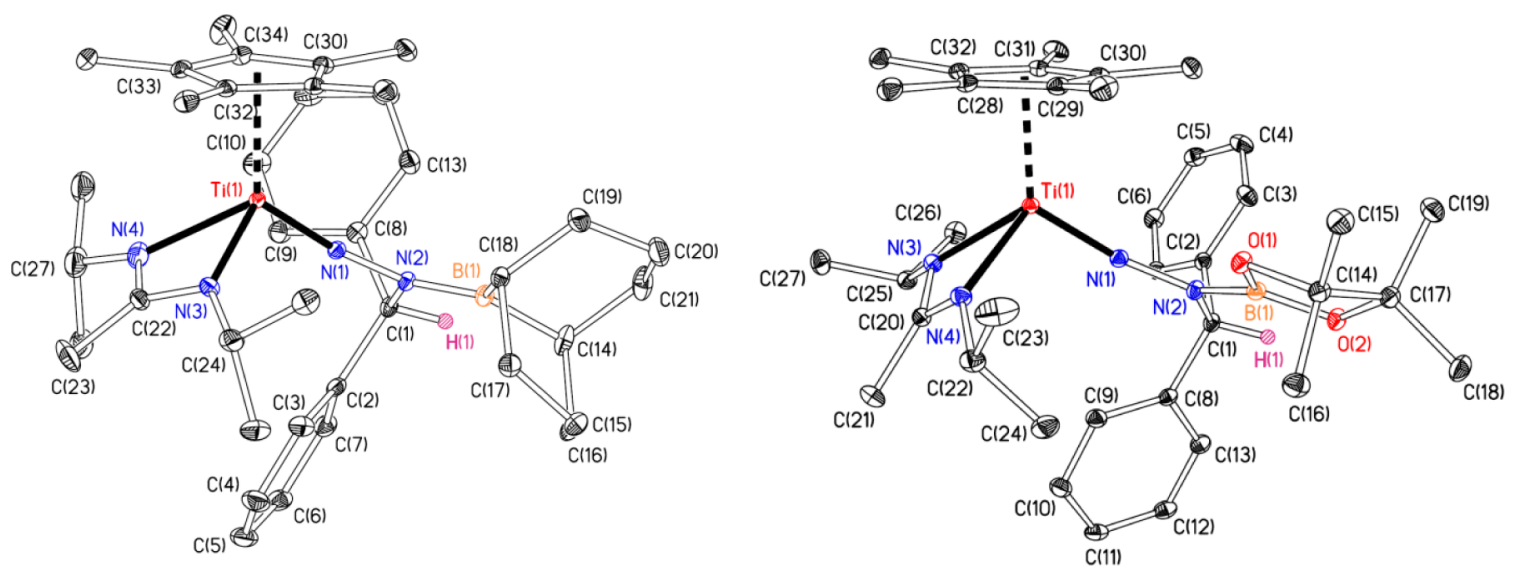

Figure 6. Displacement ellipsoid plots (25\% probability) of $\mathrm{Cp} * \mathrm{Ti}\left\{\mathrm{MeC}\left(\mathrm{N}^{\mathrm{i}} \mathrm{Pr}\right)_{2}\right\}\left\{\mathrm{NN}\left(\mathrm{BC}_{8} \mathrm{H}_{14}\right) \mathrm{CHPh}_{2}\right\} \quad(\mathbf{1 5}$, left $)$ and $\mathrm{Cp} * \mathrm{Ti}\left\{\mathrm{MeC}\left(\mathrm{N}^{\mathrm{i} P r}\right)_{2}\right\}-$ $\left\{\mathrm{NN}(\mathrm{BPin}) \mathrm{CHPh}_{2}\right\}$ (16, right). C-bound $\mathrm{H}$ atoms omitted for clarity except $\mathrm{H}(1)$ which is drawn as a sphere of an arbitrary radius. 


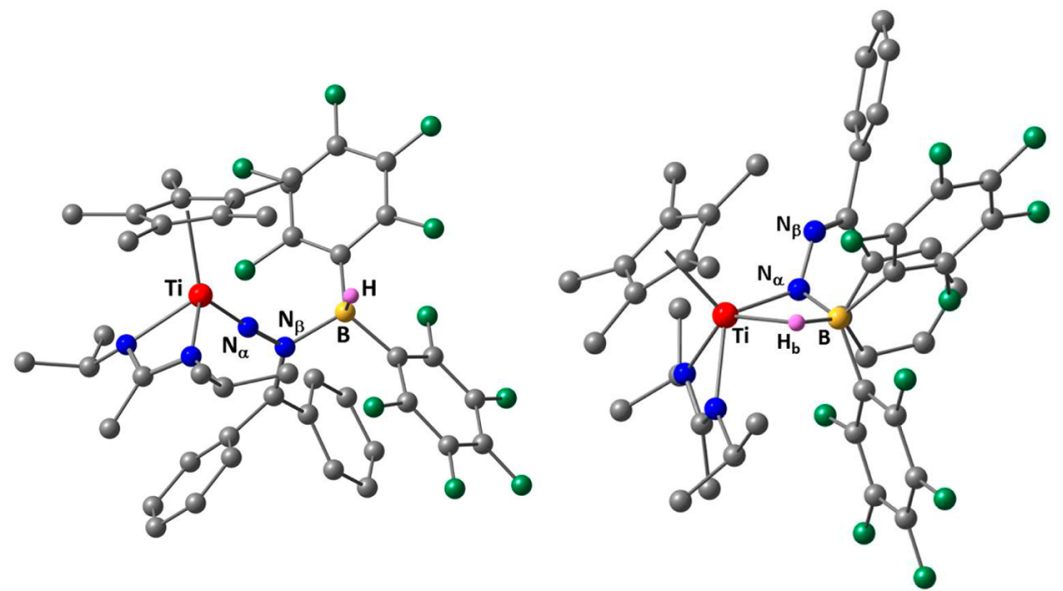

Figure 7. DFT structures of $\mathrm{Cp} * \mathrm{Ti}\left\{\mathrm{MeC}\left(\mathrm{N}^{\mathrm{i}} \mathrm{Pr}\right)_{2}\right\}\left\{\mathrm{NN}\left(\mathrm{HBAr}_{2}{ }_{2}\right) \mathrm{CPh}_{2}\right\} \quad\left(\mathbf{1 7} \mathrm{N}_{\beta}\right.$, left $)$ and $\mathrm{Cp} * \mathrm{Ti}\left\{\mathrm{MeC}\left(\mathrm{N}^{\mathrm{i} P r}\right)_{2}\right\}\left\{\mathrm{N}\left(\mathrm{HBAr}_{2}^{\mathrm{F}}\right) \mathrm{NCPh}_{2}\right\} \quad\left(\mathbf{1} 7 \mathrm{~N}_{\alpha}\right.$,

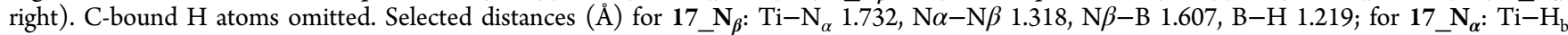
1.940, Ti- $\mathrm{N}_{\alpha} 1.785, \mathrm{~N}_{\alpha}-\mathrm{N}_{\beta} 1.351, \mathrm{~N}_{\alpha}-\mathrm{B} 1.553, \mathrm{~B}-\mathrm{H}_{\mathrm{b}} 1.295$.

to the $\mathrm{N}_{\beta}$ atom. This compound was spectroscopically characterized by NMR and solution IR spectroscopy. In particular the ${ }^{11} \mathrm{~B}$ NMR spectrum has a single resonance at $-8.5 \mathrm{ppm}$ consistent with a four-coordinate boron atom, while the IR spectrum showed a terminal $\nu(\mathrm{B}-\mathrm{H})$ band at 2591 $\mathrm{cm}^{-1}$. Over several hours at room temperature, $17 \mathrm{~N}_{\beta}$ converts to a more stable isomer, $\mathrm{Cp} * \mathrm{Ti}\left\{\mathrm{MeC}\left(\mathrm{N}^{\mathrm{i}} \mathrm{Pr}\right)_{2}\right\} \overline{\{\mathrm{N}}\left(\mathrm{HBAr}_{2}^{\mathrm{F}}\right)$ $\left.\mathrm{NCPh}_{2}\right\}\left(17 \mathbf{N}_{\alpha}\right)$ with the borane bound to $\mathrm{N}_{\alpha}$. This is an analogue of the structurally characterized tolylimido adduct $\mathrm{Cp} * \mathrm{Ti}\left\{\mathrm{MeC}\left(\mathrm{N}^{\mathrm{i}} \mathrm{Pr}\right)_{2}\right\}\left\{\mathrm{N}(\mathrm{Tol}) \mathrm{BHAr}_{2}{ }_{2}\right\}(12)$.

Compound 17_ $\mathbf{N}_{\alpha}$ is stable for at least $12-18 \mathrm{~h}$ in solution and was isolated on the preparative scale as an analytically pure, orange oil in $62 \%$ yield. Its ${ }^{11} \mathrm{~B}$ NMR shift of $-9.7 \mathrm{ppm}$ also indicates a four-coordinate boron atom, while the observed frequency for the $\nu(\mathrm{B}-\mathrm{H})$ band in the IR spectrum at 1945 $\mathrm{cm}^{-1}$ clearly indicates a bridging hydride. The corresponding values in 12 were $-7.7 \mathrm{ppm}$ and $1939 \mathrm{~cm}^{-1}$ for the ${ }^{11} \mathrm{~B}$ chemical shift and $\nu(\mathrm{B}-\mathrm{H})$, respectively. The through-space relationships were determined using $\operatorname{ROESY}\left({ }^{1} \mathrm{H}-{ }^{1} \mathrm{H}\right)$ and HOESY $\left({ }^{1} \mathrm{H}-{ }^{19} \mathrm{~F}\right)$ techniques. The DFT structures of $17 \mathbf{N}_{\beta}$ and 17_ $\mathbf{N}_{\boldsymbol{\alpha}}$ are shown in Figure 7. The computed $\nu(\mathrm{B}-\mathrm{H})$ values of 2468 and $1915 \mathrm{~cm}^{-1}$, respectively, are in agreement with the experimental trends. Finally, over four or more days at room temperature, $17 \mathbf{N}_{\boldsymbol{\alpha}}$ rearranges to $\mathrm{Cp}{ }^{*} \mathrm{Ti}\left\{\mathrm{MeC}\left(\mathrm{N}^{\mathrm{i}} \mathrm{Pr}\right)_{2}\right\}$ $\left\{\mathrm{NN}\left(\mathrm{BAr}_{2}\right) \mathrm{CHPh}_{2}\right\} \overline{(17)}$, analogous to 14-16, as indicated by ${ }^{1} \mathrm{H}$ and ${ }^{13} \mathrm{C}$ NMR resonances at 6.15 and $77.1 \mathrm{ppm}$ for the $\mathrm{NCHPh}_{2}$ group and a ${ }^{11} \mathrm{~B} \mathrm{NMR}$ shift of $33.5 \mathrm{ppm}$ for threecoordinate boron.

Table S2 of the SI lists the computed $\Delta_{\mathrm{r}} \mathrm{G}$ values for the formation of $17 \mathrm{~N}_{\beta}, 17 \mathrm{~N}_{\alpha}$, and 17 from 4 and 0.5 equiv of dimeric $\left[\mathrm{HBAr}_{2}^{\mathrm{F}}\right]_{2}$. The values of $-7.0,-7.1$, and $-15.5 \mathrm{kcal}$ $\mathrm{mol}^{-1}$, respectively, indicate that the final 1,2-addition product $\mathbf{1 7}$ is the thermodynamic isomer and that both adducts (on $\mathrm{N}_{\beta}$ and $\mathrm{N}_{\alpha}$ ) are thermodynamically viable. The calculations are not able to confidently distinguish between $17 \mathbf{N}_{\beta}$ and $17 \_\mathbf{N}_{\boldsymbol{\alpha}}$ in terms of relative stability, whereas the experimental NMR data are unambiguous in finding that $\mathbf{1 7} \mathbf{N}_{\boldsymbol{\alpha}}$ is the more stable of the two. DFT calculations were also carried out on the corresponding $\mathrm{N}_{\beta}$ and $\mathrm{N}_{\alpha}$ adducts for the reactions with 0.5 equiv of 9-BBN (i.e., 15_ $\mathbf{N}_{\beta}$ and 15_ $\mathbf{N}_{\alpha}$ ) or 1 equiv of HBPin (i.e., 16_ $\mathbf{N}_{\beta}$ and 16_ $\mathbf{N}_{\alpha}$ ), as well as the observed products themselves (15 and 16 , Table S2 of the SI). In these cases, formation of the final products $\mathbf{1 5}$ and $\mathbf{1 6}$ is clearly exergonic
$\left(\Delta_{\mathrm{r}} \mathrm{G}=-19.9\right.$ and $\left.-15.9 \mathrm{kcal} \mathrm{mol}^{-1}\right)$, but the $\mathrm{N}_{\beta}$ and $\mathrm{N}_{\alpha}$ adducts are endergonic or only very slightly exergonic, consistent with them not being observed. The different stabilities of the adducts for $\mathrm{HBAr}_{2}{ }_{2}$ are attributed to the higher Lewis acidity of the boron in this case.

Based on the experimentally observed species and the computed energies of the different adducts, we are able to propose a mechanism for the reactions of $\mathbf{4}$ with the various boranes. The reactions probably start with coordination of $\mathrm{HBR}_{2}$ to the $\mathrm{sp}^{2}$ hybridized $\beta$-nitrogen as observed in the case of $17 \mathbf{N}_{\beta}$. This would be consistent with the known electronic structure of 4 , the $\mathrm{HOMO}$ of which has a large $\mathrm{N}_{\beta}$ lone pair contribution as well as $\mathrm{Ti}-\mathrm{N}_{\alpha}$ bonding character (note that the $\mathrm{N}_{\alpha}-\mathrm{N}_{\beta}-\underline{\mathrm{CPh}}_{2}$ angle in 4 is $\left.120.2^{\circ}\right){ }^{3 \mathrm{e}}$ The same type of HOMO is found in $\mathrm{Cp}{ }^{*} \mathrm{Ti}\left\{\mathrm{MeC}\left(\mathrm{N}^{\mathrm{i}} \mathrm{Pr}\right)_{2}\right\}\left(\mathrm{NNMe}_{2}\right)\left(\mathbf{1 0}, \mathrm{sp}^{3}\right.$ hybridized $\left.\mathrm{N}_{\beta}\right)^{23}$, which is known to react exclusively at $\mathrm{N}_{\beta}$ with alkyl halides $\mathrm{RCH}_{2} \mathrm{X}(\mathrm{R}=\mathrm{H}, \mathrm{Me}$, or $\mathrm{Ph}, \mathrm{X}=\mathrm{Br}$ or $\mathrm{I})$, formally a source of $\left[\mathrm{H}_{2} \mathrm{CR}\right]^{+}$, which is valence isoelectronic with $\mathrm{HBR}_{2}$. Other terminal dimethylhydrazides also react with alkyl halides or triflates at $\mathrm{N}_{\beta}$ and have been structurally characterized for titanium ${ }^{24}$ and also molybdenum. ${ }^{25}$ In their studies of molybdenum hydrazides of relevance to the Chatt cycle for $\mathrm{N}_{2}$ fixations, Tuczek et al. showed that protonation at $\mathrm{N}_{\beta}$ can be kinetically preferred but that a rapid 1,2-proton shift can occur to form the $\mathrm{N}_{\alpha}$-protonated counterpart which is thermodynamically more stable. ${ }^{26}$

From the $\beta$-nitrogen adduct it seems that either hydride transfer to $\underline{\mathrm{CPh}_{2}}$ or $\mathrm{HBR}_{2}$ group migration to $\mathrm{N}_{\alpha}$ can occur. In the case of $\mathrm{HBAr}_{2}{ }_{2}$ the $\alpha$-nitrogen adduct is sufficiently thermodynamically stable to form. In addition, this borane has the most stabilized $\mathrm{B}-\mathrm{H}$ bond, as indicated, for example, by the structural, IR, and DFT data for Cp*Ti $\left\{\mathrm{MeC}\left(\mathrm{N}^{\mathrm{i}} \mathrm{Pr}_{2}\right)_{2}\right\}\{\mathrm{N}$ $\left.(\mathrm{Tol}) \mathrm{HBAr}_{2}{ }_{2}\right\}(12)$ where hydride transfer from $\mathrm{B}$ toward $\mathrm{Ti}$ is the least advanced. The other boranes form less stable/ endergonic $\mathrm{N}_{\alpha}$ adducts and are better hydride donors. Experimentally, $17 \mathbf{N}_{\alpha}$ eventually converts to 17 , as indicated by the dotted arrow in Scheme 2. Overall, this requires both a boron atom shift from $\mathrm{N}_{\alpha}$ to $\mathrm{N}_{\beta}$ and also hydride transfer to $\mathrm{CPh}_{2}$. The most plausible pathway for this transformation from the kinetic to the thermodynamic product is via $17 \_\mathbf{N}_{\beta}$, although alternative pathways cannot be excluded on the currently available evidence. 
It is interesting to compare the reactions of 4 with $\mathrm{PhRSiH}_{2}$ which form products of 1,3 -addition to the $\mathrm{N}-\mathrm{N}=\mathrm{CPh}_{2}$ ligand (5, Figure 1), and with $\mathrm{HBR}_{2}$ giving 14-17. In the case of the poorly Lewis acidic silanes, addition to 4 (and 10) always proceeds via concerted 1,2-addition to $\mathrm{Ti}-\mathrm{N}_{\alpha}$, generating titanium hydride species from which hydride transfer to the electrophilic $\underline{\mathrm{C}} \mathrm{Ph}_{2}$ can take place. With $\mathrm{HBR}_{2}$ 1,2-addition to $\mathrm{Ti}-\mathrm{N}_{\alpha}$ is certainly thermodynamically accessible ( $c f$. the formation of 11-13 for example), but these systems appear not to transfer their hydride completely in most cases, preferring to form the ubiquitous $\mathrm{M}-\mathrm{H}-\mathrm{B}$ bridges. In contrast, electrophilic attack at $\mathrm{N}_{\beta}$ does not stabilize the $\mathrm{B}-\mathrm{H}$ bond in this way, allowing for the facile hydride transfer seen for $\mathrm{H}_{2} \mathrm{BTex}$, 9-BBN, and HBPin.

Reactions of $\mathrm{Cp} * \mathrm{Ti}\left\{\mathrm{MeC}\left(\mathrm{N}^{\mathrm{i} P r}\right)_{2}\right\}\left(\mathrm{NNMe}_{2}\right)$ (2) with HBPin and $\mathrm{HBAr}_{2}$. The reactions of $\mathrm{Cp} \mathrm{p}^{*} \mathrm{Ti}\left\{\mathrm{MeC}\left(\mathrm{N}^{\mathrm{i} P r}\right)_{2}\right\}$ $\left(\mathrm{NNMe}_{2}\right)$ (2) with 9-BBN, HBPin, and $\mathrm{HBAr}^{\mathrm{F}}{ }_{2}$ all lead to different final product types $\left(\mathrm{H}_{2} \mathrm{BTex}\right.$ gave a mixture of unknown products, none of which could be isolated). No reaction occurred between $\mathrm{Cp} * \mathrm{Ti}\left\{\mathrm{MeC}\left(\mathrm{N}^{\mathrm{i}} \mathrm{Pr}\right)_{2}\right\}\left(\mathrm{NNPh}_{2}\right)$ (18) and any of the boranes, except for 9-BBN at elevated temperatures. The reaction of $\mathbf{2}$ with HBPin (Scheme 3)

Scheme 3. Reactions of $\mathrm{Cp}{ }^{*} \mathrm{Ti}\left\{\mathrm{MeC}\left(\mathrm{N}^{\mathrm{i}} \mathrm{Pr}_{2}\right)_{2}\right\}\left(\mathrm{NNMe}_{2}\right)$ (2) with HBPin and $\mathrm{HBAr}_{2}{ }_{2}$

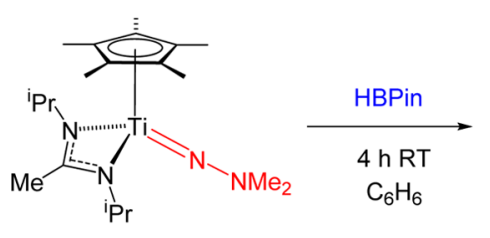

2

$$
\begin{array}{l|l}
\mathrm{HBAr}_{2} & \begin{array}{l}
2 \mathrm{~h} \mathrm{RT} \\
\mathrm{C}_{6} \mathrm{H}_{6}
\end{array}
\end{array}
$$

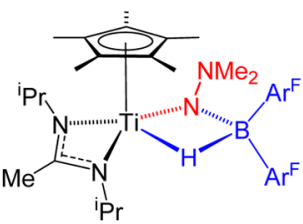

20

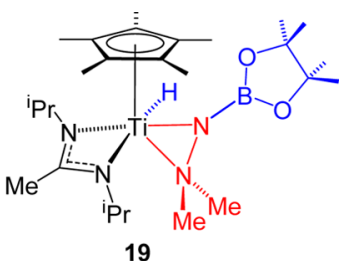

19 gave complete $\mathrm{B}-\mathrm{H}$ bond cleavage, forming $\mathrm{Cp} * \mathrm{Ti}\{\mathrm{MeC}$ $\left.\left(\mathrm{N}^{i} \mathrm{Pr}\right)_{2}\right\}(\mathrm{H})\left\{\mathrm{N}(\mathrm{BPin}) \mathrm{NMe}_{2}\right\}$ (19), which, when followed on the NMR tubes scale in $\mathrm{C}_{6} \mathrm{D}_{6}$, is the sole product. It was isolated in $53 \%$ yield as a green solid on scale-up. Diffractionquality crystals were grown from benzene, and the solid state structure is shown in Figure 8 along with selected distances and angles.

Compound 19 is a $\kappa^{2}$-borylhydrazide( $\left.1-\right)$-hydride compound, directly analogous to the compounds $\mathrm{Cp} * \mathrm{Ti}\{\mathrm{MeC}$ $\left.\left(\mathrm{N}^{i} \mathrm{Pr}\right)_{2}\right\}(\mathrm{H})\left\{\mathrm{N}\left(\mathrm{SiH}_{2} \mathrm{R}\right) \mathrm{NMe}_{2}\right\}$ (3, Figure 1) formed between 10 and primary silanes. The solid state structures of three examples of $\mathbf{3}$ have been crystallographically characterized, and the metric data for 19 are very similar. For example, the $\mathrm{Ti}(1)-$ $\mathrm{N}(1)$ and $\mathrm{N}(1)-\mathrm{N}(2)$ distances in 19 are 1.9664(10) and $1.4399(14) \AA$, respectively, and in the compounds 3 the average values are 1.960 (range $1.952(1)-1.963(3)$ ) and 1.449 (range $1.441(3)-1.460(4)) \AA$. These distances are all substantially

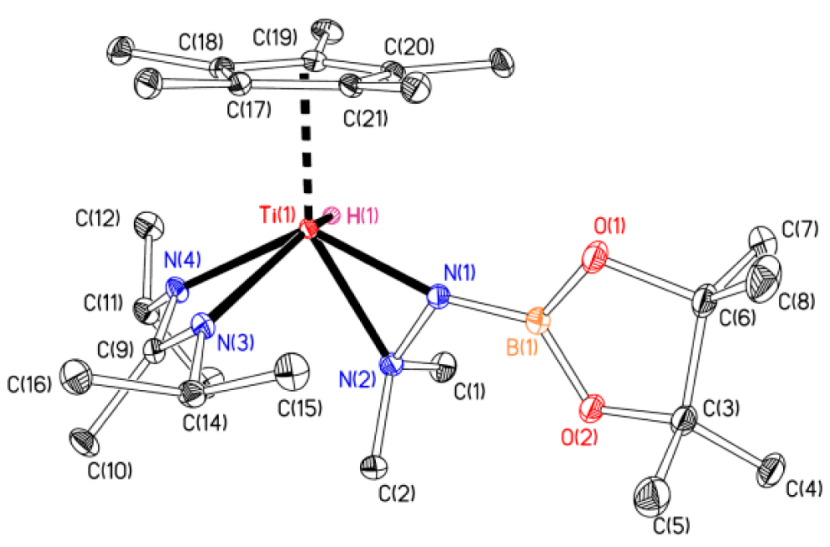

Figure 8. Displacement ellipsoid plot (25\% probability) of Cp*Ti$\left\{\mathrm{MeC}\left(\mathrm{N}^{i} \mathrm{Pr}\right)_{2}\right\}(\mathrm{H})\left\{\mathrm{N}(\mathrm{BPin}) \mathrm{NMe}_{2}\right\} \quad$ (19). C-bound $\mathrm{H}$ atoms are omitted for clarity; $\mathrm{H}(1)$ is drawn as a sphere of arbitrary radius. Selected bond distances $(\AA)$ and angles (deg): $\operatorname{Ti}(1)-\mathrm{N}(1)$ 1.9664(10), $\operatorname{Ti}(1)-\mathrm{N}(2) \quad 2.2173(11), \quad \mathrm{Ti}(1)-\mathrm{N}(3)$ 2.1835(10), $\mathrm{Ti}(1)-\mathrm{N}(4)$ 2.1893(10), $\mathrm{Ti}(1)-\mathrm{H}(1)$ 1.70(2), Ti(1)-C $\mathrm{p}_{\text {cent }} 2.08$, $\mathrm{N}(1)-\mathrm{N}(2) \quad 1.4399(14), \mathrm{N}(1)-\mathrm{B}(1) \quad 1.4183(17) ; \quad \mathrm{Cp}_{\text {cent }}-\mathrm{Ti}(1)-$ $\mathrm{N}(1)$ 114.8, $\mathrm{Cp}_{\text {cent }}-\mathrm{Ti}(1)-\mathrm{N}(3)$ 113.2, $\mathrm{Cp}_{\text {cent }}-\mathrm{Ti}(1)-\mathrm{N}(4)$ 116.6, $\mathrm{Ti}(1)-\mathrm{N}(1)-\mathrm{N}(2) 79.58(6), \mathrm{N}(2)-\mathrm{N}(1)-\mathrm{B}(1) 119.40(10)$.

lengthened from those in $\mathbf{1 0}$ itself. The hydride $\mathrm{H}(\mathbf{1})$ was located in a Fourier map and positionally and isotropically refined. The $\mathrm{Ti}(1)-\mathrm{H}(1)$ distance of $1.70(2)$ is comparable within error to those in 3 (av. 1.61, range 1.56(4)-1.64(4) $\AA$ ), given the uncertainties involved with $\mathrm{H}$ atom location using $\mathrm{X}$ ray techniques. ${ }^{27}$ The new $\mathrm{N}(\mathrm{BPin}) \mathrm{NMe}_{2}$ ligand is $\kappa^{2}$ coordinated, as is usually the case for titanium hydrazido(1-) complexes, ${ }^{24 a, 28}$ except for especially crowded systems ${ }^{28 f}$ or those with $\beta-\mathrm{NPh}_{2}$ substituents. ${ }^{28 \mathrm{i}, 29}$

The solution NMR data for 19 are consistent with the $\kappa^{2}$ borylhydrazide(1-)-hydride structure being maintained in solution. In particular, the diastereotopic $\beta-\mathrm{NMe}_{2}$ groups give rise to two ${ }^{1} \mathrm{H}$ singlet resonances at 3.01 and $2.81 \mathrm{ppm}$ of $3 \mathrm{H}$ intensity, the hydride is observed as a singlet $(1 \mathrm{H}$ intensity) at $5.57 \mathrm{ppm}$, similar to the shifts found in 3 (range 5.05-5.15 $\mathrm{ppm})$, and the ${ }^{11} \mathrm{~B}$ resonance at $23.7 \mathrm{ppm}$ is consistent with three-coordinate boron. DFT calculations were performed on 19 and on an isomer $\left(19 \kappa^{1}\right)$ with a $\kappa^{1}-\mathrm{N}(\mathrm{BPin}) \mathrm{NMe}_{2}$ ligand. Consistent with the corresponding calculations reported for $3{ }^{10 a} 19$ was found to be $-14.6 \mathrm{kcal} \mathrm{mol}^{-1}$ more stable than $19 \kappa^{1}$, and $\Delta_{\mathrm{r}} \mathrm{G}$ for the formation of 19 from 2 and HBPin was $-1 \overline{16} .7 \mathrm{kcal} \mathrm{mol}^{-1}$.

Compound 19 is also an analogue of the type of hydrazide(1-)-hydride intermediate proposed by DFT (but not experimentally observed) to be formed en route to the borylamide compound 7 (Figure 1). However, 19 was found to be stable for weeks in solution and in the solid state at RT. Upon heating to $70{ }^{\circ} \mathrm{C}$ in $\mathrm{C}_{6} \mathrm{D}_{6}$ decomposition occurs to a mixture of unidentified products. In addition, 19 did not react further with HBPin or other boranes (cf. the reaction with 9BBN described below).

In contrast to forming 19 with HBPin, the reaction of 2 with $\mathrm{HBAr}_{2}{ }_{2}$ gave $\mathrm{Cp}{ }^{*} \mathrm{Ti}\left\{\mathrm{MeC}\left(\mathrm{N}^{\mathrm{i}} \mathrm{Pr}_{2}\right)_{2}\right\}\left\{\mathrm{N}\left(\mathrm{NMe}_{2}\right) \mathrm{HBAr}_{2}{ }_{2}\right\} \quad$ (20, Scheme 3$)$ as an analytically pure red oil which we could not crystallize. The NMR and IR data, supported by DFT calculations (Figure 9) indicate the hydride-bridged structure illustrated. This is analogous to those isolated from the reactions of this borane with 10 (forming 12) and 4 (forming 17_ $\left.\mathbf{N}_{\boldsymbol{\alpha}}\right)$. The IR spectrum of 20 shows a $\nu(\mathrm{B}-\mathrm{H})$ band at 1990 

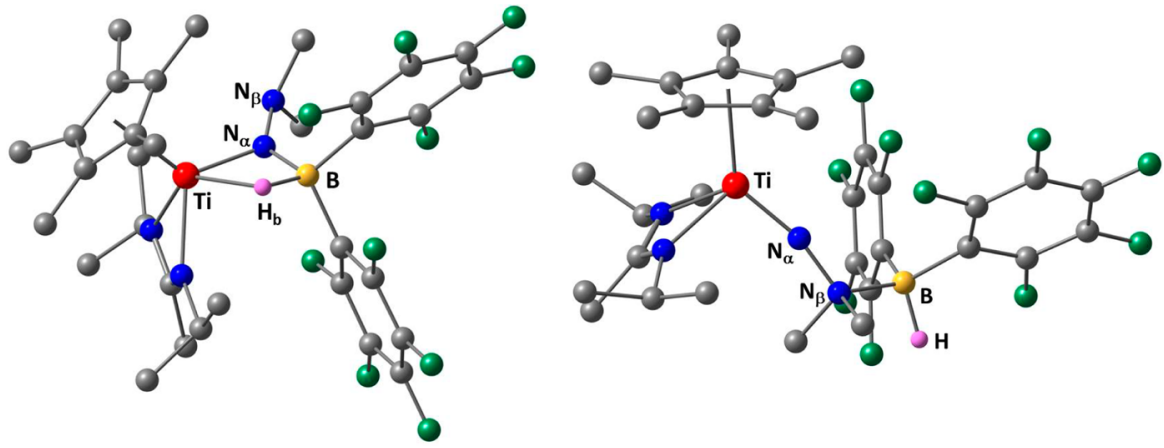

Figure 9. DFT gas phase optimized structures of $\mathrm{Cp} * \mathrm{Ti}\left\{\mathrm{MeC}\left(\mathrm{N}^{\mathrm{i}} \mathrm{Pr}_{2}\right)_{2}\right\}\left\{\mathrm{N}\left(\mathrm{NMe}_{2}\right) \mathrm{HBAr}_{2}{ }_{2}\right\}$ (20, left) and $\mathrm{Cp} * \mathrm{Ti}_{2}\left\{\mathrm{MeC}\left(\mathrm{N}^{\mathrm{i}} \mathrm{Pr}\right)_{2}\right\}\left\{\mathrm{NN}\left(\mathrm{HBAr}_{2}\right) \mathrm{Me}_{2}\right\}$ $\left(20 \_\mathbf{N}_{\beta}\right.$, right). C-bound.

$\mathrm{cm}^{-1}$ (cf. $1939 \mathrm{~cm}^{-1}$ in the crystallgraphically characterized analogue 12) for the bridging hydride. The ${ }^{11} \mathrm{~B}$ NMR spectrum shows a signal for four-coordinate boron at $-6.8 \mathrm{ppm}(c f .-7.7$ ppm in 12), and the ${ }^{1} \mathrm{H}$ NMR shows a singlet at $2.75 \mathrm{ppm}$ of intensity $6 \mathrm{H}$ for the $\beta$-NMe $\underline{\mathrm{Me}}_{2}$ groups, consistent with them undergoing free rotation/inversion on the NMR time scale because $\mathrm{N}_{\beta}$ is not coordinated to titanium.

Figure 9 compares the DFT structures of $\mathbf{2 0}$ and an isomeric structure $\mathrm{Cp} * \mathrm{Ti}\left\{\mathrm{MeC}\left(\mathrm{N}^{\mathrm{i}} \mathrm{Pr}\right)_{2}\right\}\left\{\mathrm{NN}\left(\mathrm{HBAr}_{2}^{\mathrm{F}}\right) \mathrm{Me}_{2}\right\} \quad\left(\mathbf{2 0} \mathbf{N}_{\beta}\right)$ with $\mathrm{HBAr}_{2}$ datively coordinated to the nitrogen of the $\beta$ $\mathrm{NMe}_{2}$ group, as observed in its reaction with 4 to give $20 \mathbf{N}_{\beta}$ as the first-formed product. The computed $\Delta_{\mathrm{r}} \mathrm{G}$ for formation of $20 \_\mathbf{N}_{\beta}\left(-18.6 \mathrm{kcal} \mathrm{mol}^{-1}\right)$ shows that its formation is favorable, cf. the reactions of 2 with alkyl halides at $\mathrm{N}_{\beta}$ to give $\left[\mathrm{Cp}^{*} \mathrm{Ti}\left\{\mathrm{MeC}\left(\mathrm{N}^{\mathrm{i} P r}\right)_{2}\right\}\left(\mathrm{NNMe}_{2} \mathrm{R}\right)\right]^{+}$as discussed above. However, $\Delta_{\mathrm{r}} \mathrm{G}$ for the formation of 20 is $-29.9 \mathrm{kcal} \mathrm{mol}^{-1}, 11.3 \mathrm{kcal}$ $\mathrm{mol}^{-1}$ more exergonic. The computed $\nu(\mathrm{B}-\mathrm{H})$ frequencies for 20 and 20_ $\mathbf{N}_{\beta}$ are 1912 and $2412 \mathrm{~cm}^{-1}$, again consistent with 20 being the experimentally observed product. We also evaluated by DFT the reaction of 2 with $\mathrm{HBAr}^{\mathrm{F}}{ }_{2}$ to form the $\mathrm{B}-\mathrm{H}$ bond cleavage product $\mathrm{Cp} * \mathrm{Ti}\left\{\mathrm{MeC}\left(\mathrm{N}^{i} \mathrm{Pr}\right)_{2}\right\}(\mathrm{H})\{\mathrm{N}-$ $\left.\left(\mathrm{BAr}_{2}{ }_{2}\right) \mathrm{NMe}_{2}\right\}$ (analogous to 19). This is also exergonic with respect to the reactants $\left(\Delta_{\mathrm{r}} \mathrm{G}=-21.8 \mathrm{kcal} \mathrm{mol}^{-1}\right)$ but significantly endergonic $\left(\Delta_{\mathrm{r}} \mathrm{G}=+8.1 \mathrm{kcal} \mathrm{mol}^{-1}\right)$ with respect to $\mu$-hydride isomer 20 , consistent with the higher Lewis acidity and poorer hydride-donating ability of $\mathrm{HBAr}_{2}{ }_{2}$ in these systems.

Reactions of $\mathrm{Cp} * \mathrm{Ti}\left\{\mathrm{MeC}\left(\mathrm{N}^{\mathrm{i} P r}\right)_{2}\right\}\left(\mathrm{NNR}_{2}\right)(\mathrm{R}=\mathrm{Me}(2)$ or $\mathrm{Ph}$ (18)) with 9-BBN. The reaction of $\mathrm{Cp} * \mathrm{Ti}\left\{\mathrm{MeC}\left(\mathrm{N}^{\mathrm{i}} \mathrm{Pr}\right)_{2}\right\}$ $\left(\mathrm{NNR}_{2}\right)(\mathrm{R}=\mathrm{Me}(\mathbf{2})$ or $\mathrm{Ph}(\mathbf{1 8}))$ with $9-\mathrm{BBN}$ is summarized in eq 1 . Reaction of 2 at room temperature or of 18 at $60{ }^{\circ} \mathrm{C}$

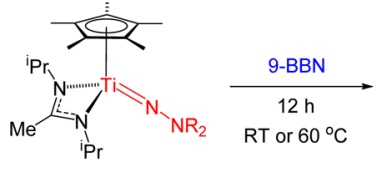

$\mathrm{R}=\mathrm{Me}(\mathbf{2})$ or $\mathrm{Ph}(\mathbf{1 8})$

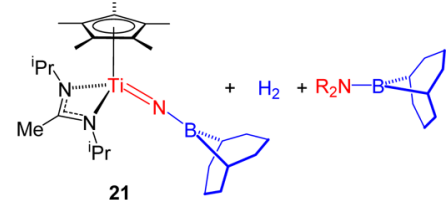

Equation 1

(no reaction at room temperature) with 1 equiv of 9-BBN dimer $(\mathrm{Ti}: \mathrm{B}=1: 2)$ in $\mathrm{C}_{6} \mathrm{D}_{6}$ gave full conversion of the hydrazide and all of the 9-BBN to a $1: 1$ mixture of $\mathrm{Cp}{ }^{*} \mathrm{Ti}\left\{\mathrm{MeC}\left(\mathrm{N}^{\mathrm{i}} \mathrm{Pr}\right)_{2}\right\}\left(\mathrm{NBC}_{8} \mathrm{H}_{14}\right)$ (21) and the corresponding aminoborane $\mathrm{R}_{2} \mathrm{NBC}_{8} \mathrm{H}_{14}(\mathrm{R}=\mathrm{Me}$ or $\mathrm{Ph}) .{ }^{30}$ An additional singlet at $4.46 \mathrm{ppm}$ was assigned to eliminated $\mathrm{H}_{2}$. The reaction for 2 was successfully scaled up. The aminoborane $\mathrm{Me}_{2} \mathrm{NBC}_{8} \mathrm{H}_{14}$ was separated by careful high vacuum sub- limation $\left(85-90{ }^{\circ} \mathrm{C}, 2 \times 10^{-5} \mathrm{mbar}\right)$, leaving 21 as an analytically pure, green powder. Diffraction-quality crystals of 21 were grown from hexane. The solid state structure is shown in Figure 10 together with selected bond distances and angles.

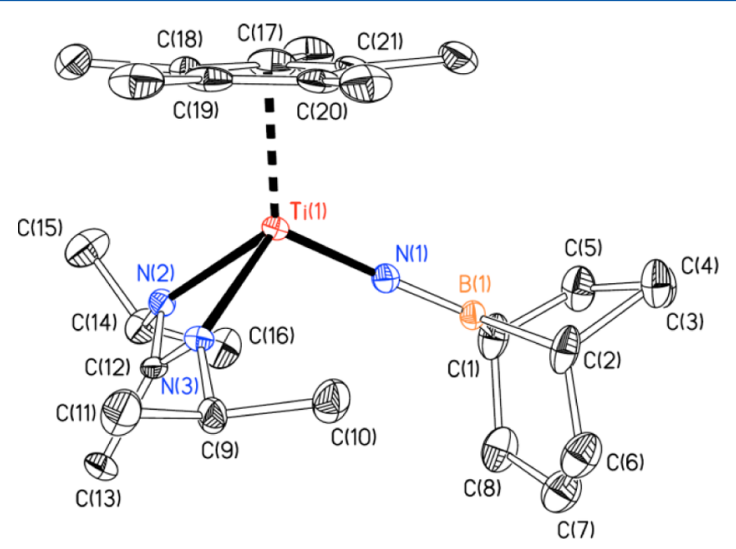

Figure 10. Displacement ellipsoid plot $(20 \%$ probability $)$ of $\mathrm{Cp}^{*} \mathrm{Ti}\left\{\mathrm{MeC}\left(\mathrm{N}^{\mathrm{i}} \mathrm{Pr}\right)_{2}\right\}\left(\mathrm{NBC}_{8} \mathrm{H}_{14}\right) \quad(\mathbf{2 1}) . \mathrm{H}$ atoms are omitted for clarity. Selected bond distances $(\AA)$ and angles (deg): $\mathrm{Ti}(1)-\mathrm{N}(1)$ 1.731(3), $\mathrm{Ti}(1)-\mathrm{N}(2)$ 2.091(4), $\mathrm{Ti}(1)-\mathrm{N}(3)$ 2.065(4), $\mathrm{Ti}(1)-\mathrm{Cp}_{\text {cent }}$ 2.07, $\mathrm{N}(1)-\mathrm{B}(1)$ 1.402(4), $\mathrm{B}(1)-\mathrm{C}(1)$ 1.523(12), $\mathrm{B}(1)-\mathrm{C}(2)$ $1.580(8) ; \quad \mathrm{Cp}_{\text {cent }}-\mathrm{Ti}(1)-\mathrm{N}(1)$ 118.9, $\mathrm{Cp}_{\text {cent }}-\mathrm{Ti}(1)-\mathrm{N}(2)$ 122.4, $\mathrm{Cp}_{\text {cent }}-\mathrm{Ti}(1)-\mathrm{N}(3)$ 122.3, $\mathrm{Ti}(1)-\mathrm{N}(1)-\mathrm{B}(1) \quad 178.4(3), \mathrm{N}(2)-$ $\mathrm{Ti}(1)-\mathrm{N}(1) 107.65(19), \mathrm{N}(3)-\mathrm{Ti}(1)-\mathrm{N}(1) 108.6(2)$.

On scale up in benzene at $60{ }^{\circ} \mathrm{C}$, compound 18 reacted quantitatively with 1 equiv of 9-BBN dimer to form 21, along with $\mathrm{Ph}_{2} \mathrm{NBC}_{8} \mathrm{H}_{14}$ and $\mathrm{H}_{2}$. It was not possible to separate $\mathrm{Ph}_{2} \mathrm{NBC}_{8} \mathrm{H}_{14}$ from 21: the lower volatility of this aminoborane led to longer sublimation times and higher temperatures, giving thermal degradation of 21 . Use of only 0.5 equiv of $9-\mathrm{BBN}$ (Ti:B ratio of $1: 1$ ) in the NMR tube scale reactions gave incomplete conversion, confirming the stoichiometry required by eq 1 .

Compound $\mathbf{2 1}$ is a rare example of a borylimide, for which only a few examples have previously been reported. ${ }^{5, c, 31}$ The ${ }^{11} \mathrm{~B}$ NMR spectrum shows a singlet at $52.8 \mathrm{ppm}$ (calculated $52.9 \mathrm{ppm}$ for the DFT model of 21) consistent with threecoordinate boron and very similar to the value of $54.5 \mathrm{ppm}$ for the borylamide ligand in $\mathrm{Ti}\left(\mathrm{N}_{2} \mathrm{~N}^{\mathrm{Me}}\right)\left\{\mathrm{N}(\mathrm{H}) \mathrm{BC}_{8} \mathrm{H}_{14}\right\}\left(\mathrm{NPh}_{2}\right)(7$, Figure 1). ${ }^{5 \mathrm{~b}}$ The IR spectrum shows no bands attributable to either $\nu(\mathrm{B}-\mathrm{H})$ or $\nu(\mathrm{Ti}-\mathrm{H})$. The solid state structure of 21 (Figure 11) possesses a three-legged piano stool geometry. The parameters associated with the $\mathrm{Cp}{ }^{*} \mathrm{Ti}\left\{\mathrm{MeC}\left(\mathrm{N}^{\mathrm{i}} \mathrm{Pr}\right)_{2}\right\}$ moiety are within the expected ranges. The $\mathrm{Ti}(1)-\mathrm{N}(1)$ bond length 

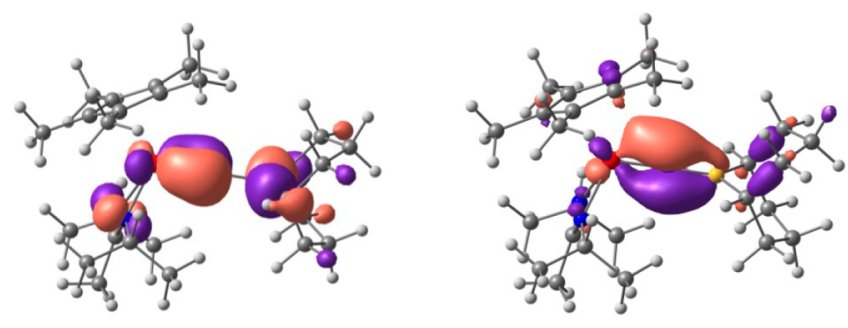

$\mathrm{Ti}-\mathbf{N}_{\alpha}\left(\pi_{1}\right)(-4.98 \mathrm{eV})$
$\operatorname{Ti}-N_{\beta}\left(\pi_{2}\right)(-6.73 \mathrm{eV})$

Figure 11. Two $\mathrm{Ti}-\mathrm{N}_{\alpha} \pi$-bonding $\mathrm{MOs}$ of $\mathrm{Cp} * \mathrm{Ti}\left\{\mathrm{MeC}\left(\mathrm{N}^{\mathrm{i} P r}\right)_{2}\right\}$ $\left(\mathrm{NBC}_{8} \mathrm{H}_{14}\right)(\mathbf{2 1})$ and their energies. Isosurfaces are drawn at the 0.032 au level.

of 1.731(3) $\AA$ and linear $\mathrm{Ti}(1)-\mathrm{N}(1)-\mathrm{B}(1)$ angle $178.4(3)^{\circ}$ is indicative of a $\mathrm{Ti}-\mathrm{N}_{\alpha}$ triple bond as confirmed by DFT calculations (cf. Figure 11). The $\mathrm{Ti}(1)-\mathrm{N}(1)$ distance lies in the range of typical values for titanium arylimido compounds (ca. $1.70-1.74)^{21}$ and can be compared with previously reported xylylimido, hydrazido, and tert-butoxyimido titanium homologues, $\mathrm{Cp}{ }^{*} \mathrm{Ti}\left\{\mathrm{MeC}\left(\mathrm{N}^{\mathrm{i} P r}\right)_{2}\right\}(\mathrm{NR})(\mathrm{R}=\mathrm{Xyl}(1.738(2)$ $\AA), \mathrm{NPh}_{2}(1.734(2) \AA), \mathrm{NMePh}(1.734(2) \AA), \mathrm{NMe}_{2}$ $(1.723(2) \AA)$, and $\left.\mathrm{O}^{t} \mathrm{Bu}(1.709(3) \AA)\right)$, as well as that in Cp*Ti $\left\{\mathrm{MeC}\left(\mathrm{N}^{\mathrm{i}} \mathrm{Pr}\right)_{2}\right\}\left\{\mathrm{NN}\left(\mathrm{BC}_{8} \mathrm{H}_{14}\right) \mathrm{CHPh}_{2}\right\}$ (15) above.

Mindiola has reported two examples of titanium borylimides, namely 22 (from the corresponding parent imide with 2 equiv of $\left.\mathrm{NaHBEt}_{3}\right)^{5 \mathrm{a}}$ and $\mathbf{2 3}$ (by reaction of a metalated nitride with ClBCat). ${ }^{5 \mathrm{c}}$ The $\mathrm{Ti}-\mathrm{N}_{\alpha}$ distances of $1.722(3)$ and $1.7312(2) \AA$, respectively, are equivalent within error to that in $\mathbf{2 1}$.<smiles>[3H]N1C(Br)=C(Br)C(N)(Br)N1B(CC)CC</smiles>

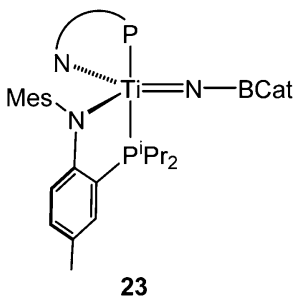

Figure 11 shows the two principal Ti- $\mathrm{N}_{\alpha} \pi$-bonding molecular orbitals (denoted $\pi_{1}$ and $\pi_{2} ; \sigma$-bonding MO not shown) calculated for 21. This is consistent with the $\mathrm{Ti}-\mathrm{N}_{\alpha}$ triple bond description. The energy difference of $1.75 \mathrm{eV}$ between $\pi_{1}$ and $\pi_{2}$ is substantial because of stabilization of the latter $\mathrm{Ti}-\mathrm{N}_{\alpha} \pi$-interaction by delocalization to the otherwise vacant $2 \mathrm{p}$ atomic orbital of the boron atom, as also indicated by the relatively short $\mathrm{N}(1)-\mathrm{B}(1)$ distance of $1.402(4) \AA$.

Further NMR tube scale experiments were carried out to probe the reaction of $\mathrm{Cp} * \mathrm{Ti}\left\{\mathrm{MeC}\left(\mathrm{N}^{\mathrm{i}} \mathrm{Pr}\right)_{2}\right\}\left(\mathrm{NNR}_{2}\right)$ with 9$\mathrm{BBN}$. Thus, following the reaction for 2 at room temperature established that the evolutions of 21 and $\mathrm{Me}_{2} \mathrm{NBC}_{8} \mathrm{H}_{14}$ were correlated (along with evolution of $\mathrm{H}_{2}$ ). Analogous results were found for 18, and no free $\mathrm{HNMe}_{2}$ or $\mathrm{HNPh}_{2}$ or their borane adducts were observed. When $\mathrm{HNPh}_{2}$ and 0.5 equiv of 9-BBN were heated together under the same concentration as in the NMR experiments with 18, the formation of $\mathrm{Ph}_{2} \mathrm{NBC}_{8} \mathrm{H}_{14}$ was found to be much slower ( $48 \mathrm{~h} c f .12 \mathrm{~h}$ starting from 18 and 9$\mathrm{BBN}$ ). No intermediates were observed in the reactions of $\mathbf{1 8}$ either at $60{ }^{\circ} \mathrm{C}$ or at lower temperatures. In the case of 2 , however, monitoring the reaction with $9-\mathrm{BBN}$ at $0{ }^{\circ} \mathrm{C}$ in $\mathrm{C}_{7} \mathrm{D}_{8}$ showed the formation of a new species 21 int, which featured resonances comparable to those of $\mathrm{Cp} * \mathrm{Ti}\left\{\mathrm{MeC}\left(\mathrm{N}^{i} \mathrm{Pr}\right)_{2}\right\}(\mathrm{H})$ $\left\{\mathrm{N}(\mathrm{BPin}) \mathrm{NMe}_{2}\right\}$ (19), suggesting the formation of a

borylhydrazide(1-)-hydride compound. Warming up the NMR sample containing 21 int led to the consumption of it and unreacted 9-BBN and formation of $21, \mathrm{Me}_{2} \mathrm{NBC}_{8} \mathrm{H}_{14}$, and $\mathrm{H}_{2}$, as in the room temperature reactions. Attempts to isolate 21_int were unsuccessful, and upon evaporation of the volatiles from the reaction mixtures unknown products were obtained.

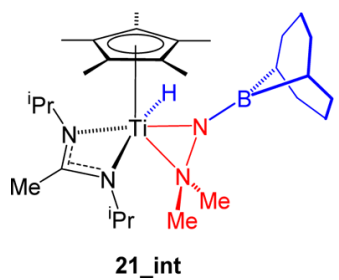

The ${ }^{11} \mathrm{~B}$ NMR spectrum of 21 int showed a downfield resonance at $28.1 \mathrm{ppm}$. The ${ }^{1} \mathrm{H} \overline{\mathrm{N}} \mathrm{MR}$ spectrum showed a singlet of intensity $1 \mathrm{H}$ at $6.30 \mathrm{ppm}$ which did not correlate to any $\mathrm{H}$ or $\mathrm{C}$ atoms and is assigned as $\mathrm{Ti}-\underline{\mathrm{H}}$. The $\beta-\mathrm{NMe}_{2}$ groups gave rise to overlapping broad signals (relative intensity $3 \mathrm{H}$ each) at 2.75 and $2.65 \mathrm{ppm}$. The structure of 21 int was

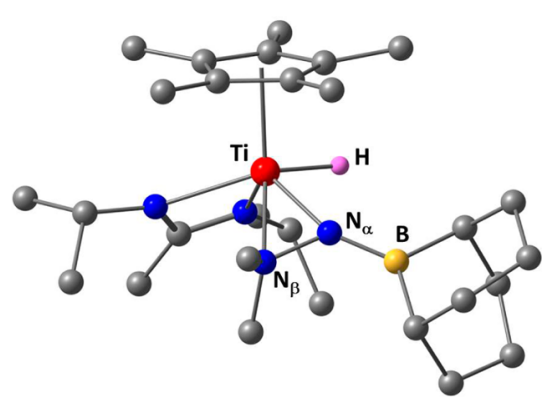

Figure 12. DFT structure of $\mathrm{Cp} * \mathrm{Ti}\left\{\mathrm{MeC}\left(\mathrm{N}^{\mathrm{i} P r}\right)_{2}\right\}(\mathrm{H})\left\{\mathrm{N}\left(\mathrm{BC}_{8} \mathrm{H}_{14}\right)\right.$ $\left.\mathrm{NMe}_{2}\right\}$ (21 int). C-bound $\mathrm{H}$ atoms omitted. Selected distances $(\AA)$ : $\mathrm{Ti}-\mathrm{H}$ 1.660, Ti-N $\mathrm{N}_{\alpha} 1.956, \mathrm{~N}_{\alpha}-\mathrm{N}_{\beta} 1.416, \mathrm{~B}-\mathrm{N}_{\alpha} 1.400$.

computed by DFT and is shown in Figure 12. The calculated ${ }^{11} \mathrm{~B}$ NMR shift for 21 int of $32.0 \mathrm{ppm}$ is in good agreement with the experimental value. Unfortunately, we have been unable to establish by experiment or DFT further details of a possible mechanism leading from 21 int and 9-BBN to the product borylimide and amidoborane. It is known in dehydrocoupling of amine-boranes in general that $\mathrm{B}-\mathrm{N}$ coupling and $\mathrm{H}_{2}$ elimination can be correlated in various ways. ${ }^{32}$ Further speculation at this stage is inappropriate.

\section{CONCLUSIONS}

In this contribution we have significantly expanded upon our initial report of the reaction of the titanium hydrazide $\mathrm{Ti}\left(\mathrm{N}_{2} \mathrm{~N}^{\mathrm{Me}}\right)\left(\mathrm{NNPh}_{2}\right)$ (py) with 9-BBN to give $\mathrm{Ti}\left(\mathrm{N}_{2} \mathrm{~N}^{\mathrm{Me}}\right)\{\mathrm{N}$ $\left.(\mathrm{H}) \mathrm{BC}_{8} \mathrm{H}_{14}\right\}\left(\mathrm{NPh}_{2}\right)(7$, Figure 1) and its homologue with HBMes $_{2}$. The wider range of imido and hydrazido compounds available with the $\mathrm{Cp} *\left\{\mathrm{MeC}\left(\mathrm{N}^{\mathrm{i}} \mathrm{Pr}\right)_{2}\right\}$ ligand set, which is tolerant to a variety of borane substituents, allowed us to make a broader assessment of the types of adducts, 1,2-addition, and $\mathrm{B}-\mathrm{H} / \mathrm{N}_{\alpha}-\mathrm{N}_{\beta}$ cleavage processes accessible in this chemistry. In the case of $\mathrm{Cp}{ }^{*} \mathrm{Ti}\left\{\mathrm{MeC}\left(\mathrm{N}^{\mathrm{i}} \mathrm{Pr}\right)_{2}\right\}(\mathrm{NTol})$ only hydride-bridged adducts $\mathrm{Cp}{ }^{*} \mathrm{Ti}\left\{\mathrm{MeC}\left(\mathrm{N}^{\mathrm{i}} \mathrm{Pr}_{2}\right)_{2}\right\}\left\{\mathrm{N}(\mathrm{Tol}) \mathrm{HBRR}^{\prime}\right\}$ without $\mathrm{B}-\mathrm{H}$ bond cleavage were formed. These are structurally related to Lancaster's $\mathrm{Cp}_{2} \mathrm{Hf}\left\{\mathrm{N}(\mathrm{H}) \mathrm{HBAr}_{2}{ }_{2}\right\}$ (9) but are in contrast to Walter's $\left(\eta-\mathrm{C}_{5} \mathrm{H}_{2}{ }^{\mathrm{t}} \mathrm{Bu}_{3}\right)_{2} \mathrm{Th}(\mathrm{H})\left\{\mathrm{N}\left(\mathrm{BC}_{8} \mathrm{H}_{14}\right) \mathrm{Tol}\right\}$, which exists as a terminal hydride-borylamide derivative, and also Chen's 8 
(Figure 1), although in this case the hydride was stabilized by further reaction with 9-BBN.

The reactions of $\mathrm{Cp}{ }^{*} \mathrm{Ti}\left\{\mathrm{MeC}\left(\mathrm{N}^{\mathrm{i}} \mathrm{Pr}\right)_{2}\right\}\left(\mathrm{NNCPh}_{2}\right)$ (4) with boranes follow fundamentally different pathways to the one with silanes which gives $\mathrm{Si}-\mathrm{H}$ 1,3-addition products to the $\mathrm{NNCPh}_{2}$ ligand, forming 3 (Figure 1). The observed $\beta$ nitrogen and $\alpha$-nitrogen adducts formed with $\mathrm{HBAr}_{2}{ }_{2}$ prior to the final product $\mathrm{Cp}{ }^{*} \mathrm{Ti}\left\{\mathrm{MeC}\left(\mathrm{N}^{\mathrm{i}} \mathrm{Pr}\right)_{2}\right\}\left\{\mathrm{NN}\left(\mathrm{BAr}_{2}^{\mathrm{F}}\right) \mathrm{CHPh}_{2}\right\}$ (17) allow insight into the possible mechanism of the reactions of the other boranes studied with 4 . The Lewis acidity of boron, the availibility of a $\beta$-nitrogen lone pair in 4 , and the general absence of hydride formation by 1,2-addition to $\mathrm{Ti}-\mathrm{N}_{\alpha}$ explain the reaction pathways taken. The reaction of $\mathrm{Cp}{ }^{*} \mathrm{Ti}\{\mathrm{MeC}$ $\left.\left(\mathrm{N}^{\mathrm{i}} \mathrm{Pr}_{2}\right)_{2}\right\}\left(\mathrm{NNMe}_{2}\right)$ (2) with HBPin is the most similar, of all the reactions of boranes reported, to the corresponding one with primary silanes. The $\mathrm{B}-\mathrm{H}$ bond cleavage product is stabilized by $\beta-\mathrm{NMe}_{2}$ coordination, as in the silane reaction products. With $\mathrm{HBAr}_{2}{ }_{2}$ the effect of the higher Lewis acidity of boron is evidenced by the incomplete transfer of hydride to titanium. The reaction of $\mathbf{2}$ with 9-BBN is especially interesting in terms of forming a rare example of a borylimido compound, and it suggests that this type of reaction may be accessible for other early transition metal hydrazido complexes.

\section{EXPERIMENTAL SECTION}

General methods and instrumentation. All manipulations were carried out using standard Schlenk line or glovebox techniques under an atmosphere of argon or dinitrogen. Solvents were either degassed by sparging with dinitrogen and dried by passing through a column of the appropriate drying agent ${ }^{33}$ or refluxed over sodium (toluene), potassium $(\mathrm{THF}), \mathrm{Na} / \mathrm{K}$ alloy $\left(\mathrm{Et}_{2} \mathrm{O}\right)$ or and distilled. Deuterated solvents were dried over sodium $\left(\mathrm{C}_{7} \mathrm{D}_{8}\right)$ or potassium $\left(\mathrm{C}_{6} \mathrm{D}_{6}\right)$ distilled under reduced pressure and stored under argon in Teflon valve ampules. NMR samples were prepared under dinitrogen in $5 \mathrm{~mm}$ Wilmad 507-PP tubes fitted with J. Young Teflon valves. ${ }^{1} \mathrm{H},{ }^{13} \mathrm{C}\left\{{ }^{1} \mathrm{H}\right\}$, ${ }^{11} \mathrm{~B}\left\{{ }^{1} \mathrm{H}\right\}$ and ${ }^{19} \mathrm{~F}\left\{{ }^{1} \mathrm{H}\right\}$ spectra were recorded on a Bruker Ascend 400 NMR spectrometer, a Bruker Advance III 500 NMR spectrometer or on a Bruker AVC 500 spectrometer fitted with a ${ }^{13} \mathrm{C}$ cryoprobe. Unless otherwise stated, all NMR spectra were recorded at $298 \mathrm{~K} .{ }^{1} \mathrm{H}$ and ${ }^{13} \mathrm{C}\left\{{ }^{1} \mathrm{H}\right\}$ and spectra were referenced internally to residual protiosolvent $\left({ }^{1} \mathrm{H}\right)$ or solvent $\left({ }^{13} \mathrm{C}\right)$ resonances, and are reported relative to tetramethylsilane $(\delta=0 \mathrm{ppm}) .{ }^{19} \mathrm{~F}$ and ${ }^{11} \mathrm{~B}$ NMR spectra were referenced externally to $\mathrm{CFCl}_{3}$ and $\mathrm{Et}_{2} \mathrm{O} \cdot \mathrm{BF}_{3}$ respectively. Assignments were confirmed as necessary with the use of two-dimensional ${ }^{1} \mathrm{H}-{ }^{1} \mathrm{H},{ }^{13} \mathrm{C}-{ }^{1} \mathrm{H},{ }^{1} \mathrm{H}-{ }^{19} \mathrm{~F}$ and ${ }^{19} \mathrm{~F}-{ }^{19} \mathrm{~F}$ correlation experiments. Chemical shifts are quoted in $\delta(\mathrm{ppm})$ and coupling constants in Hz. Unless otherwise stated, IR spectra were recorded on a Thermo Scientific Nicolet iS5 FTIR spectrometer and samples prepared in a drybox using $\mathrm{NaCl}$ plates as a Nujol mull or as a thin film. The data are quoted in wavenumbers $\left(\mathrm{cm}^{-1}\right)$. Mass spectra were recorded by the mass spectrometry service of Oxford University's Department of Chemistry. Elemental analyses were carried out by the Elemental Analysis Service at the London Metropolitan University.

Starting materials. $\mathrm{Cp} * \mathrm{Ti}\left\{\mathrm{MeC}\left(\mathrm{N}^{\mathrm{i}} \mathrm{Pr}\right)_{2}\right\}(\mathrm{NR})\left(\mathrm{R}={ }^{\mathrm{t}} \mathrm{Bu}\right.$ or $\mathrm{Tol}$ (10)), ${ }^{22 \mathrm{~d}} \mathrm{Cp}{ }^{*} \mathrm{Ti}\left\{\mathrm{MeC}\left(\mathrm{N}^{\mathrm{i}} \mathrm{Pr}\right)_{2}\right\}\left(\mathrm{NO}^{\mathrm{t}} \mathrm{Bu}\right),{ }^{4 \mathrm{a}, b} \mathrm{Cp}^{*} \mathrm{Ti}\left\{\mathrm{MeC}\left(\mathrm{N}^{\mathrm{i} P r}\right)_{2}\right\}-$ $\left(\mathrm{NNR}_{2}\right)\left(\mathrm{R}_{2}=\mathrm{Me}_{2}(\mathbf{2}), \mathrm{Ph}_{2}(\mathbf{1 8})\right.$ or $\left.\mathrm{CPh}_{2}(\mathbf{4})\right),{ }^{\mathrm{e}, 23} \mathrm{HBCy}_{2},{ }_{16}$ $\mathrm{H}_{2} \mathrm{BTex},{ }^{15} \mathrm{HBAr}^{\mathrm{F}}{ }_{2}{ }^{12,34} \mathrm{HBMes}_{2},{ }^{17} \mathrm{HB}\left(\mathrm{NAr}{ }^{\prime} \mathrm{CH}\right)_{2},{ }^{18} \mathrm{HB}-$ $\left(\mathrm{N}^{\mathrm{i} P \mathrm{PrCH}}\right)_{2}{ }^{19}$ were synthesized according to literature procedures. Other boranes were obtained from commercial source and used without additional purification.

Syntheses. $\left.C p * \operatorname{Ti}\left\{\mathrm{MeC}\left(\mathrm{N}^{i} \mathrm{Pr}\right)_{2}\right\}\left\{\mathrm{N}(\mathrm{Tol}) \mathrm{H}_{2} B \mathrm{BTex}\right)\right\}$ (11). To a stirred solution of $\mathrm{Cp}^{*} \mathrm{Ti}\left\{\mathrm{MeC}\left(\mathrm{N}^{\mathrm{i} P r}\right)_{2}\right\}(\mathrm{NTol})(\mathbf{1 0}, 0.300 \mathrm{~g}, 0.669 \mathrm{mmol})$ in benzene $(10 \mathrm{~mL})$ was added $\mathrm{H}_{2} \mathrm{BTex}(0.065 \mathrm{~g}, 0.669 \mathrm{mmol})$ at RT. The solution was left to stir at RT for $12 \mathrm{~h}$, filtered and volatiles removed under reduced pressure to afford the adduct as a yellow oil. This was triturated with pentane to give $\mathbf{1 1}$ as a yellow/brown solid which was washed with cold pentane $(3 \times 10 \mathrm{~mL})$ and dried in vacuo.
Yield $0.263 \mathrm{~g}$ (75\%). Diffraction-quality crystals were grown from pentane at RT.

${ }^{1} \mathrm{H}$ NMR $\left(\mathrm{C}_{6} \mathrm{D}_{6}, 400.1 \mathrm{MHz}, 298 \mathrm{~K}\right): \delta 7.02(4 \mathrm{H}$, overlapping $m$ $\mathrm{C}_{6} \underline{\mathrm{H}}_{4} \mathrm{Me}$ and $\left.o-\mathrm{C}_{6} \underline{\mathrm{H}}_{4} \mathrm{Me}\right), 3.73\left(1 \mathrm{H}\right.$, broad, $\left.\mathrm{C}_{3} \mathrm{Me}_{2}\right), 3.51(1 \mathrm{H}$, broad, $\left.\mathrm{CH}_{\mathrm{b}} \mathrm{Me}_{2}\right) 2.23\left(3 \mathrm{H}, \mathrm{s}, \mathrm{C}_{6} \mathrm{H}_{4} \mathrm{Me}\right), 2.03(1 \mathrm{H}, \mathrm{m}$, $\left.\mathrm{BCMe}_{2} \mathrm{CHMe}_{2}\right), 1.85\left(15 \mathrm{H}, \mathrm{s}, \mathrm{C}_{5} \underline{\mathrm{Me}}_{5}\right), 1.66\left(3 \mathrm{H}, \mathrm{s}, \underline{\mathrm{MeCN}_{2}}\right)$, $1.34\left(3 \mathrm{H}, \mathrm{d},{ }^{3} \mathrm{~J}=6.5 \mathrm{~Hz}, \mathrm{NCH}_{\mathrm{a}} \mathrm{MeMe}\right), 1.30(6 \mathrm{H}, \mathrm{d}$, $\left.\mathrm{BCMe}_{2} \mathrm{CHMe}_{2}\right), 1.26\left(3 \mathrm{H}, \mathrm{d},{ }^{3} \mathrm{~J}=6.5 \mathrm{~Hz}, \mathrm{NCH}_{\mathrm{a}} \mathrm{MeMe}\right), 1.21$ (3 $\left.\mathrm{H}, \mathrm{d},{ }^{3} J=6.5 \mathrm{~Hz}, \mathrm{NCH}_{\mathrm{b}} \mathrm{MeMe}\right), 1.15\left(3 \mathrm{H}, \mathrm{d},{ }^{3} J=6.5 \mathrm{~Hz}\right.$, $\left.\mathrm{NCH}_{\mathrm{b}} \mathrm{MeMe}\right), 1.01-0.96\left(6 \mathrm{H}\right.$, overlapping, $\left.\mathrm{BCMe}{ }_{2} \mathrm{CHMe}_{2}\right)$. ${ }^{13} \mathrm{C}\left\{{ }^{1} \mathrm{H}\right\}$ NMR $\left(\mathrm{C}_{6} \mathrm{D}_{6}, 100.6 \mathrm{MHz}, 298 \mathrm{~K}\right): \delta 164.7\left(\mathrm{MeCN}_{2}\right)$, $154.6\left(i-\underline{C}_{6} \mathrm{H}_{4} \mathrm{Me}\right), 132.4\left(p-\underline{\mathrm{C}}_{6} \mathrm{H}_{4} \mathrm{Me}\right), 130.4\left(m-\underline{\mathrm{C}}_{6} \mathrm{H}_{4} \mathrm{Me}\right), 122.8(o-$ $\left.\underline{\mathrm{C}}_{6} \mathrm{H}_{4} \mathrm{Me}\right), 121.8\left(\underline{\mathrm{C}}_{5} \mathrm{Me}_{5}\right), 50.7\left(\mathrm{~N}_{\mathrm{CH}} \mathrm{Me}_{2}\right), 48.7\left(\mathrm{~N}_{\mathrm{CH}} \mathrm{Me}_{2}\right), 37.1$ $\left(\mathrm{BCMe}_{2} \mathrm{CHMe}_{2}\right), 26.0\left(\mathrm{BCMeMeCHMe}{ }_{2}\right), 25.3\left(\mathrm{BCMeMeCHMe}_{2}\right)$, $23.9\left(\mathrm{NCH}_{\mathrm{b}} \mathrm{MeMe}\right), 23.0\left(\mathrm{NCH}_{\mathrm{b}} \underline{\mathrm{MeMe}}\right), 24.31\left(\mathrm{NCH}_{\mathrm{a}} \underline{\mathrm{MeMe}}\right), 19.5$ $\left(\mathrm{NCH}_{\mathrm{a}} \mathrm{MeMe}\right), 18.7\left(\mathrm{BCMe}_{2} \mathrm{CHMe}_{2}\right), 21.02\left(\mathrm{C}_{6} \mathrm{H}_{4} \mathrm{Me}\right), 14.9$ $\left(\underline{\mathrm{MeCN}_{2}}\right), 11.7\left(\mathrm{C}_{5} \underline{\mathrm{Me}}_{5}\right) \mathrm{ppm} .{ }^{11} \mathrm{~B}\left\{{ }^{1} \mathrm{H}\right\}$ NMR $\left(\mathrm{C}_{6} \mathrm{D}_{6}, 128.4 \mathrm{MHz}\right.$, $298 \mathrm{~K}$ ): 1.5 (s) ppm. IR ( $\mathrm{NaCl}$ plates, Nujol mull, $\left.\mathrm{cm}^{-1}\right): 2327$ (s, terminal $\nu(\mathrm{B}-\mathrm{H})), 1908(\mathrm{~m}$, bridging $\nu(\mathrm{B}-\mathrm{H})), 1599(\mathrm{w}), 1455(\mathrm{~s})$, 1378 (s), 1303 (s), 1130 (s), 1110 (s), 1079 (m), 1044 (m), 924 (w), $847(\mathrm{w}), 835(\mathrm{w}), 818(\mathrm{w}), 607(\mathrm{w})$. EI-MS: $m / z=527[M-H]^{+}$ (20\%), $324\left[M-\left\{\mathrm{N}(\mathrm{Tol}) \mathrm{BH}_{2} \mathrm{Tex}\right\}\right]^{+}(80 \%)$. Anal. found (calcd. for $\mathrm{C}_{31} \mathrm{H}_{54} \mathrm{BN}_{3} \mathrm{Ti}$ ): $\mathrm{C} 67.72$ (70.59), $\mathrm{H} 10.50$ (10.32), N 7.32 (7.97). The sample gave persistently low \%, $\mathrm{N}$ analysis, even of diffraction-quality crystals.

$C p * \operatorname{Ti}\left\{\mathrm{MeC}\left(\mathrm{NiPr}_{2}\right\}\left\{\mathrm{N}(\mathrm{Tol}) \mathrm{BHAr}_{2}{ }_{2}\right\}\right.$ (12). To a stirred solution of $\mathrm{Cp}^{*} \mathrm{Ti}\left\{\mathrm{MeC}\left(\mathrm{N}^{\mathrm{i} P r}\right)_{2}\right\}(\mathrm{NTol})(\mathbf{1 0}, 0.300 \mathrm{~g}, 0.669 \mathrm{mmol})$ in benzene $(10 \mathrm{~mL})$ was added $\operatorname{HBAr}_{2}{ }_{2}(0.231 \mathrm{~g}, 0.669 \mathrm{mmol})$ at RT. The solution was stirred at RT for $12 \mathrm{~h}$, filtered and the volatiles removed under reduced pressure to afford brown oil. This was triturated with pentane to give 12 as a brown solid which was washed with cold pentane $(3 \times 10 \mathrm{~mL})$ and dried in vacuo. Yield: $0.306 \mathrm{~g}(60 \%)$. Diffraction-quality crystals were grown from pentane at RT.

${ }^{1} \mathrm{H}$ NMR $\left(\mathrm{C}_{6} \mathrm{D}_{6}, 400.1 \mathrm{MHz}, 298 \mathrm{~K}\right): \delta 6.94\left(2 \mathrm{H}, \mathrm{d},{ }^{3} \mathrm{~J}=8.5 \mathrm{~Hz}\right.$, $\left.m-\mathrm{C}_{6} \underline{\mathrm{H}}_{4} \mathrm{Me}\right), 6.67\left(2 \mathrm{H}, \mathrm{d},{ }^{3} \mathrm{~J}=8.5 \mathrm{~Hz}, o-\mathrm{C}_{6} \underline{\mathrm{H}}_{4} \mathrm{Me}\right), \delta 3.04(2 \mathrm{H}$, br. s, $\left.\mathrm{C}^{\mathrm{H}} \mathrm{Me}_{2}\right), 2.11\left(3 \mathrm{H}, \mathrm{s}, \mathrm{C}_{6} \mathrm{H}_{4} \underline{\mathrm{Me}}\right), 1.78\left(15 \mathrm{H}, \mathrm{s}, \mathrm{C}_{5} \underline{\mathrm{Me}}_{5}\right), 1.37(3 \mathrm{H}, \mathrm{s}$, $\left.\mathrm{MeCN}_{2}\right), 1.09\left(6 \mathrm{H}, \mathrm{d},{ }^{3} \mathrm{~J}=6.7 \mathrm{~Hz}, \mathrm{CHMe}_{2}\right), 0.80\left(6 \mathrm{H}, \mathrm{d},{ }^{3} \mathrm{~J}=6.7 \mathrm{~Hz}\right.$, $\left.\mathrm{CHMe}_{2}\right)$ ppm. ${ }^{13} \mathrm{C}\left\{{ }^{1} \mathrm{H}\right\}$ NMR $\left(\mathrm{C}_{6} \mathrm{D}_{6}, 100.6 \mathrm{MHz}, 298 \mathrm{~K}\right): \delta 163.6$ $\left(\mathrm{Me}_{\underline{C}}\right), 156.01\left(i-\underline{\mathrm{C}}_{6} \mathrm{H}_{4} \mathrm{Me}\right), 148.5$ (br. d, $\left.{ }^{1} J=236.4 \mathrm{~Hz}, o-\underline{\mathrm{C}}_{6} \mathrm{~F}_{5}\right)$, 140.3-138.2 (overlapping br. d, $p-\underline{C}_{6} \mathrm{~F}_{5}$ and $\left.m-\underline{C}_{6} \mathrm{~F}_{5}\right), 132.5$ (br, $i$ $\left.\underline{\mathrm{C}}_{6} \mathrm{~F}_{4}\right), 133.3\left(p-\underline{\mathrm{C}}_{6} \mathrm{H}_{4} \mathrm{Me}\right), 128.2\left(m-\underline{\mathrm{C}}_{6} \mathrm{H}_{4} \mathrm{Me}\right), 122.2\left(o-\underline{\mathrm{C}}_{6} \mathrm{H}_{4} \mathrm{Me}\right)$, $126.6\left(\underline{\mathrm{C}}_{5} \mathrm{Me}_{5}\right), 49.4 \quad\left(\mathrm{NCHMe}_{2}\right), 26.8$ ( $\left.{ }^{2}{ }_{\mathrm{CHMeMe}}\right), 24.3$ (NCHMeMe), $19.6\left(\mathrm{C}_{6} \mathrm{H}_{4} \underline{\mathrm{Me}}\right), 14.6\left(\underline{\left.\mathrm{MeCN}_{2}\right)}, 12.4\left(\mathrm{C}_{5} \mathrm{Me}_{5}\right) \mathrm{ppm}\right.$. ${ }^{11} \mathrm{~B}\left\{{ }^{1} \mathrm{H}\right\}$ NMR $\left(\mathrm{C}_{6} \mathrm{D}_{6}, 128.4 \mathrm{MHz}, 298 \mathrm{~K}\right):-7.7$ (s) ppm. ${ }^{19} \mathrm{~F}\left\{{ }^{1} \mathrm{H}\right\}$ NMR (470.1 MHz, $298 \mathrm{~K}):-133.4\left(o-\mathrm{C}_{6} \underline{\mathrm{E}}_{5}\right),-158.2\left(m-\mathrm{C}_{6} \underline{\mathrm{F}}_{5}\right)$, $-164.4\left(p-\mathrm{C}_{6} \mathrm{~F}_{5}\right)$. IR ( $\mathrm{NaCl}$ plates, Nujol mull, $\left.\mathrm{cm}^{-1}\right): 1939$ (s, $\nu(\mathrm{B}-$ H)), 1530 (s), 1410 (m), 1094 (s), 1083 (s), 1015 (s), 971 (w), 833 $(\mathrm{w}), 813(\mathrm{w}), 662(\mathrm{w})$. EI-MS: $m / z=775[M]^{+}(50 \%)$. Anal. found (calcd. for $\mathrm{C}_{37} \mathrm{H}_{40} \mathrm{BF}_{10} \mathrm{~N}_{3} \mathrm{Ti}$ ): C, 57.32 (57.93); H, 5.20 (5.53); N, 5.42 (5.37) \%.

$C p * T i\left\{M e C\left(N^{i} P r\right)_{2}\right\}\left\{N(T o l) H B C_{8} H_{14}\right\}$ (13). To a stirred solution of $\mathrm{Cp}^{*} \mathrm{Ti}\left\{\mathrm{MeC}\left(\mathrm{N}^{\mathrm{i} P r}\right)_{2}\right\}(\mathrm{NTol})(\mathbf{1 0}, 0.300 \mathrm{~g}, 0.669 \mathrm{mmol})$ in benzene $(10 \mathrm{~mL})$ was added $9-\mathrm{BBN}(0.085 \mathrm{~g}, 0.348 \mathrm{mmol})$ at RT. The solution was left to stir at RT for $12 \mathrm{~h}$, filtered and volatiles removed under reduced pressure to afford $\mathbf{1 3}$ as a viscous yellow/brown oil, which could not be crystallized and was washed with cold pentane $(3 \times 10$ $\mathrm{mL})$ and dried in vacuo. Yield: $0.184 \mathrm{~g}(50 \%)$.

${ }^{1} \mathrm{H}$ NMR $\left(\mathrm{C}_{6} \mathrm{D}_{6}, 400.1 \mathrm{MHz}, 298 \mathrm{~K}\right): \delta 6.98\left(2 \mathrm{H}, \mathrm{d},{ }^{3} J=8.5 \mathrm{~Hz}\right.$, $\left.m-\mathrm{C}_{6} \underline{\mathrm{H}}_{4} \mathrm{Me}\right), 6.87\left(2 \mathrm{H}, \mathrm{d},{ }^{3} \mathrm{~J}=8.5 \mathrm{~Hz}, o-\mathrm{C}_{6} \underline{\mathrm{H}}_{4} \mathrm{Me}\right), \delta 3.55(2 \mathrm{H}, \mathrm{br} . \mathrm{s}$, $\left.\mathrm{CHMe}_{2}\right), 2.10\left(3 \mathrm{H}, \mathrm{s}, \mathrm{C}_{6} \mathrm{H}_{4} \mathrm{Me}\right), 1.95\left(15 \mathrm{H}, \mathrm{s}, \mathrm{C}_{5} \mathrm{Me}_{5}\right), 1.66(3 \mathrm{H}, \mathrm{s}$,

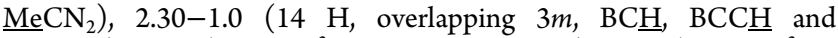
BCCCH $), 1.14\left(6 \mathrm{H}, \mathrm{d},{ }^{3} \mathrm{~J}=6.7 \mathrm{~Hz}, \mathrm{CHMe}_{2}\right), 1.01\left(6 \mathrm{H}, \mathrm{d},{ }^{3} \mathrm{~J}=\right.$ $6.7 \mathrm{~Hz}, \mathrm{CHMe} 2)$ ppm. ${ }^{13} \mathrm{C}\left\{{ }^{1} \mathrm{H}\right\} \mathrm{NMR}\left(\mathrm{C}_{6} \mathrm{D}_{6}, 100.6 \mathrm{MHz}, 298 \mathrm{~K}\right): \delta$ $163.5\left(\mathrm{Me} \underline{\mathrm{CN}}_{2}\right), 158.6 \quad\left(i-\underline{\mathrm{C}}_{6} \mathrm{H}_{4} \mathrm{Me}\right), 130.8 \quad\left(p-\underline{C}_{6} \mathrm{H}_{4} \mathrm{Me}\right), 128.3$ (overlapping $o-\underline{\mathrm{C}}_{6} \mathrm{H}_{4} \mathrm{Me}$ and $\left.m-\underline{\mathrm{C}}_{6} \mathrm{H}_{4} \mathrm{Me}\right), 125.4\left(\underline{\mathrm{C}}_{5} \mathrm{Me}_{5}\right), 120.2$ (4$\left.\underline{\mathrm{C}}_{6} \mathrm{H}_{4} \mathrm{Me}\right), 49.4\left(\mathrm{NC} \mathrm{HMe}_{2}\right), 33.7(\mathrm{BCCH}), 25.9$ ( $\left.\mathrm{NCHMeMe}\right), 25.1$ (NCHMeMe), $24.4(\mathrm{BCCCH}), 20.6\left(\mathrm{C}_{6} \mathrm{H}_{4} \mathrm{Me}\right), 11.2(\mathrm{BCH}), 13.6$ $\left(\underline{\left.\mathrm{MeCN}_{2}\right)}, 12.5\left(\mathrm{C}_{5} \mathrm{Me}_{5}\right) \mathrm{ppm} .{ }^{11} \mathrm{~B}\left\{{ }^{1} \mathrm{H}\right\} \mathrm{NMR}\left(\mathrm{C}_{6} \mathrm{D}_{6}, 128.4 \mathrm{MHz}, 298\right.\right.$ K): 10.4 (s) ppm. IR (NaCl plates, Nujol mull, $\left.\mathrm{cm}^{-1}\right): 1651$ (s, $\nu$ (BH)), 1517 (w), 1376 (w), 1260 (s), 1092 (s), 1093 (s), 1019 (s), 800 
(s). EI-MS: $m / z=551[M]^{+}(2 \%)$. A satisfactory elemental analysis of this oil, which readlily dissociates 9-BBN (see the main text), could not be obtained.

$C p * T i\left\{M e C\left(N^{i} P r\right)_{2}\left\{N N(B H T e x) C H P h_{2}\right\}\right.$ (14). To a stirred solution of $\mathrm{Cp}{ }^{*} \mathrm{Ti}\left\{\mathrm{MeC}\left(\mathrm{N}^{\mathrm{P}} \mathrm{Pr}\right)_{2}\right\}\left(\mathrm{NNCPh}_{2}\right)(4,0.300 \mathrm{~g}, 0.579 \mathrm{mmol})$ in benzene $(10 \mathrm{~mL})$ was added $\mathrm{H}_{2} \mathrm{BTex}(0.057 \mathrm{~g}, 0.579 \mathrm{mmol})$ at RT. The solution was stirred for $12 \mathrm{~h}$ at RT, filtered and volatiles were removed under reduced pressure. The resultant orange oil was washed with cold pentane and dried in vacuo to afford $\mathbf{1 4}$ as a viscous yellow oil which could not be crystallized. Yield: $0.260 \mathrm{~g}(70 \%)$.

${ }^{1} \mathrm{H}$ NMR $\left(\mathrm{C}_{6} \mathrm{D}_{6}, 400.0 \mathrm{MHz}, 298 \mathrm{~K}\right): \delta 7.47\left(4 \mathrm{H}, \mathrm{d},{ }^{3} J=8.0 \mathrm{~Hz}, o-\right.$ $\left.\mathrm{C}_{6} \mathrm{H}_{5}\right), 7.14\left(4 \mathrm{H}, \mathrm{m}, m-\mathrm{C}_{6} \mathrm{H}_{5}\right), 7.09\left(2 \mathrm{H}, \mathrm{m}, p-\mathrm{C}_{6} \mathrm{H}_{5}\right), 5.74(1 \mathrm{H}, \mathrm{s}$, $\left.\mathrm{CHPh}_{2}\right), 3.52\left(2 \mathrm{H}\right.$, app. sept., $\left.{ }^{3} J=7.0 \mathrm{~Hz}, \mathrm{NC} \underline{\mathrm{HMeMe}}\right), 2.05(15 \mathrm{H}$,

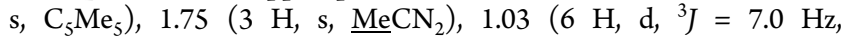
$\mathrm{NCHMe} 2), 0.88\left(7 \mathrm{H}\right.$, overlapping $\mathrm{BHCMe} \mathrm{CHMe}_{2}$ and $\left.\mathrm{BHCMe}_{2} \mathrm{CHMe}_{2}\right), 0.79\left(6 \mathrm{H}, \mathrm{BHCMe}_{2} \mathrm{CHMe}_{2}\right) 0.78\left(6 \mathrm{H}, \mathrm{d},{ }^{3} \mathrm{~J}=\right.$ $\left.7.0 \mathrm{~Hz}, \mathrm{NCHMe}{ }_{2}\right) .{ }^{13} \mathrm{C}\left\{{ }^{1} \mathrm{H}\right\} \mathrm{NMR}\left(\mathrm{C}_{6} \mathrm{D}_{6}, 100.0 \mathrm{MHz}, 298 \mathrm{~K}\right): \delta$ $161.2\left(\mathrm{MeCN}_{2}\right), 142.4\left(i-\underline{C}_{6} \mathrm{H}_{5}\right), 129.4\left(o-\underline{\mathrm{C}}_{6} \mathrm{H}_{5}\right), 127.4\left(p-\underline{\mathrm{C}}_{6} \mathrm{H}_{5}\right)$, $126.4\left(m-\underline{\mathrm{C}}_{6} \mathrm{H}_{5}\right), 119.3\left(\underline{\mathrm{C}}_{5} \mathrm{Me}_{5}\right), 66.6\left(\mathrm{CHPh}_{2}\right), 49.1\left(\mathrm{~N}^{\mathrm{C}} \mathrm{HMe}_{2}\right)$, $25.2\left(\mathrm{NCHMe}_{2}\right), 26.0\left(\mathrm{BHCMe}_{2} \mathrm{CHMe}_{2}\right), 23.7\left(\mathrm{BHCMe}_{2} \mathrm{CHMe}_{2}\right)$, $23.4\left(\mathrm{BCHMe}_{2} \mathrm{CHMe}_{2}\right), 18.7\left(\mathrm{BCHMe}_{2} \mathrm{CHMe} 2\right), 18.6\left(\mathrm{NCHMe}_{2}\right)$, $11.7\left(\mathrm{C}_{5} \mathrm{Me}_{5}\right),{ }^{11} \mathrm{~B}\left\{{ }^{1} \mathrm{H}\right\}$ NMR $\left(\mathrm{C}_{6} \mathrm{D}_{6}, 128.4 \mathrm{MHz}, 298 \mathrm{~K}\right): 46.4(\mathrm{~s})$ ppm. Anal. found (calcd. for $\mathrm{C}_{37} \mathrm{H}_{47} \mathrm{BN}_{4} \mathrm{Ti}$ ): C, 72.84 (73.28); $\mathrm{H}, 9.32$ (9.38); N, 9.09 (9.24) \%.

$C p * T i\left\{M e C\left(N{ }^{i} P r\right){ }_{2}\left\{N N\left(B C_{8} H_{14}\right) C H P h_{2}\right\}\right.$ (15). To a stirred solution of $\mathrm{Cp} * \mathrm{Ti}\left\{\mathrm{MeC}\left(\mathrm{N}^{\mathrm{i} P r}\right)_{2}\right\}\left(\mathrm{NNCPh}_{2}\right)(4,0.338 \mathrm{~g}, 0.652 \mathrm{mmol})$ in benzene $(10 \mathrm{~mL})$ was added 9 -BBN $(0.080 \mathrm{~g}, 0.326 \mathrm{mmol})$ at RT. The solution was stirred for $12 \mathrm{~h}$ at $\mathrm{RT}$, filtered and volatiles were removed under reduced pressure to afford $\mathbf{1 5}$ as a brown powder. The product was washed with cold pentane $(3 \times 10 \mathrm{~mL})$ and dried in vacuo. Yield: $0.280 \mathrm{~g}(67 \%)$. Diffraction-quality crystals were grown from a concentrated benzene solution at RT.

${ }^{1} \mathrm{H}$ NMR $\left(\mathrm{C}_{6} \mathrm{D}_{6}, 400.0 \mathrm{MHz}, 298 \mathrm{~K}\right): \delta 7.42\left(4 \mathrm{H}, \mathrm{dd},{ }^{3} J=8.1\right.$ $\left.\mathrm{MHz}, o-\mathrm{C}_{6} \underline{\mathrm{H}}_{5}\right), 7.14\left(4 \mathrm{H}, \mathrm{m}, m-\mathrm{C}_{6} \underline{\mathrm{H}}_{5}\right), 7.06\left(2 \mathrm{H}, \mathrm{m}, p-\mathrm{C}_{6} \underline{\mathrm{H}}_{5}\right), 5.96$ $\left(1 \mathrm{H}, \mathrm{s}, \mathrm{CHPh}_{2}\right), 3.52\left(2 \mathrm{H}\right.$, app. sept., $\left.{ }^{3} \mathrm{~J}=6.3 \mathrm{~Hz}, \mathrm{NC} \underline{\mathrm{HMeMe}}\right)$, 2.30-1.0 (14 H, overlapping 3m, BCH, BCCH and BCCCH $), 1.95$ $\left(15 \mathrm{H}, \mathrm{s}, \mathrm{C}_{5} \mathrm{Me}_{5}\right), 1.73\left(3 \mathrm{H}, \mathrm{s}, \underline{\mathrm{MeCN}}_{2}\right), 0.96\left(6 \mathrm{H}, \mathrm{d},{ }^{3} J=6.3 \mathrm{~Hz}\right.$, $\left.\mathrm{NCHMe}_{2}\right), 0.83\left(6 \mathrm{H}, \mathrm{d},{ }^{3} \mathrm{~J}=6.3 \mathrm{~Hz}, \mathrm{NCHMe} 2\right) .{ }^{13} \mathrm{C}\left\{{ }^{1} \mathrm{H}\right\} \mathrm{NMR}$ $\left(\mathrm{C}_{6} \mathrm{D}_{6}, 100.0 \mathrm{MHz}, 298 \mathrm{~K}\right): \delta 161.4\left(\mathrm{MeCN}_{2}\right), 142.4\left(i-\mathrm{C}_{6} \mathrm{H}_{5}\right), 129.4$ $\left(o-\underline{\mathrm{C}}_{6} \mathrm{H}_{5}\right), 127.4\left(p-\underline{\mathrm{C}}_{6} \mathrm{H}_{5}\right), 126.4\left(m-\underline{\mathrm{C}}_{6} \mathrm{H}_{5}\right), 119.7\left(\underline{\mathrm{C}}_{5} \mathrm{Me}_{5}\right), 68.5$ $\left(\mathrm{CHPh}_{2}\right), 48.8\left(\mathrm{~N} \underline{\mathrm{CHMe}}{ }_{2}\right), 33.4(\mathrm{BC} \mathrm{H}), 25.9\left(\mathrm{NCHMe}_{2}\right), 25.3$

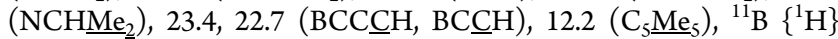
NMR $\left(\mathrm{C}_{6} \mathrm{D}_{6}, 128.4 \mathrm{MHz}, 298 \mathrm{~K}\right): 52.5$ (s) ppm. IR ( $\mathrm{NaCl}$ plates, Nujol mull, cm ${ }^{-1}$ ): 1489 (w), 1418 (m), 1325 (w), 1308 (w), 1260 (s), 1214 (w), 1092 (s), 1020 (s) 800 (s), 695 (w), 668 (m). Anal. found (calcd. for $\mathrm{C}_{39} \mathrm{H}_{57} \mathrm{BN}_{4} \mathrm{Ti}$ ): C, 73.12 (72.88); H, 8.97 (9.15); N, $8.75(8.62) \%$.

$\mathrm{Cp} * \mathrm{Ti}\left\{\mathrm{MeC}\left(\mathrm{N}^{i} \mathrm{Pr}\right)_{2}\left\{\mathrm{NN}(\mathrm{Bpin}) \mathrm{CHPh}_{2}\right\}\right.$ (16). To a stirred solution of $\mathrm{Cp} * \mathrm{Ti}\left\{\mathrm{MeC}\left(\mathrm{N}^{\mathrm{i} P r}\right)_{2}\right\}\left(\mathrm{NNCPh}_{2}\right)(4,0.210 \mathrm{~g}, 0.549 \mathrm{mmol})$ in benzene $(10 \mathrm{~mL})$ was added HBpin $(0.079 \mathrm{~mL}, 0.549 \mathrm{mmol})$ at RT. An immediate color change from dark brown to dark green was observed after $30 \mathrm{~min}$. The solution was filtered and volatiles removed under reduced pressure to give $\mathbf{1 6}$ as a brown solid which was washed with cold pentane $(3 \times 10 \mathrm{~mL})$ a dried in vacuo. Yield: $0.177 \mathrm{~g}(50 \%)$. Diffraction-quality crystals were grown from a concentrated benzene solution at RT.

${ }^{1} \mathrm{H}$ NMR $\left(\mathrm{C}_{6} \mathrm{D}_{6}, 400.0 \mathrm{MHz}, 298 \mathrm{~K}\right): \delta 7.49\left(4 \mathrm{H}, \mathrm{dd},{ }^{3} J=7.4 \mathrm{~Hz}\right.$, $\left.o-\mathrm{C}_{6} \underline{\mathrm{H}}_{5}\right), 7.19\left(4 \mathrm{H}, \mathrm{m}, m-\mathrm{C}_{6} \underline{\mathrm{H}}_{5}\right), 7.11\left(2 \mathrm{H}, \mathrm{t}, p-\mathrm{C}_{6} \underline{\mathrm{H}}_{5}\right), 5.55(1 \mathrm{H}, \mathrm{s}$, $\left.\mathrm{CHPh}_{2}\right), 3.62\left(2 \mathrm{H}\right.$, app. sept., $\left.{ }^{3} \mathrm{~J}=6.1 \mathrm{~Hz}, \mathrm{NC} \underline{\mathrm{HMeMe}}\right), 2.13(15 \mathrm{H}$, $\left.\mathrm{s}, \mathrm{C}_{5} \underline{\mathrm{Me}}_{5}\right), 1.81\left(3 \mathrm{H}, \mathrm{s}, \underline{\mathrm{MeCN}_{2}}\right), 1.14\left(6 \mathrm{H}, \mathrm{d},{ }^{3} \mathrm{~J}=6.5 \mathrm{~Hz}, \mathrm{BOC} \underline{\mathrm{Me}}_{2}\right)$, $1.07\left(6 \mathrm{H}, \mathrm{d},{ }^{3} J=6.1 \mathrm{~Hz}, \mathrm{NCHMe} 2\right), 0.80\left(6 \mathrm{H}, \mathrm{d},{ }^{3} J=6.1 \mathrm{~Hz}\right.$, $\left.\mathrm{NCHMe}_{2}\right) .{ }^{13} \mathrm{C}\left\{{ }^{1} \mathrm{H}\right\}$ NMR $\left(\mathrm{C}_{6} \mathrm{D}_{6}, 100.0 \mathrm{MHz}, 298 \mathrm{~K}\right): \delta 161.4$ $\left(\mathrm{MeCN} \underline{C N}_{2}\right), 143.7\left(i-\underline{\mathrm{C}}_{6} \mathrm{H}_{5}\right), 130.0\left(o-\underline{\mathrm{C}}_{6} \mathrm{H}_{5}\right), 127.9\left(p-\underline{\mathrm{C}}_{6} \mathrm{H}_{5}\right), 127.7(m-$ $\left.\mathrm{C}_{6} \mathrm{H}_{5}\right), 119.4\left(\underline{\mathrm{C}}_{5} \mathrm{Me}_{5}\right), 82.9\left(\mathrm{BOCMe}_{2}\right), 66.1\left(\mathrm{CHPh}_{2}\right), 49.5$ $\left(\mathrm{NCHMe}_{2}\right), 26.7$ (NCHMeMe), 25.5 (NCHMeMe), 24.9 $\left(-\mathrm{BOCMe}_{2}\right), 12.5\left(\mathrm{C}_{5} \mathrm{Me}_{5}\right), 12.0\left(\mathrm{MeCN}_{2}\right) .{ }^{11} \mathrm{~B}\left\{{ }^{1} \mathrm{H}\right\}$ NMR $\left(\mathrm{C}_{6} \mathrm{D}_{6}\right.$, $128.4 \mathrm{MHz}, 298 \mathrm{~K}): \delta 44.9 \mathrm{ppm}$. IR $\left(\mathrm{NaCl}\right.$ plates, Nujol mull, $\left.\mathrm{cm}^{-1}\right)$ : $1599(\mathrm{~m}), 1462(\mathrm{~s}), 1352(\mathrm{~m}), 1309(\mathrm{w}), 1260(\mathrm{~m}), 1145(\mathrm{w}), 1133$ (m), 1083 (m), 1065 (m), 1018 (m), 971 (w), 799 (s), 740 (w) 700 (w), 649 (w). Anal. found (calcd. for $\mathrm{C}_{37} \mathrm{H}_{55} \mathrm{BN}_{4} \mathrm{O}_{2} \mathrm{Ti}$ ): C, 68.70 (68.57); H, 8.57 (8.59); N, 8.67 (8.49) \%.

NMR tube scale synthesis of Cp*Ti\{MeC(NiPr) $\left.\left.)_{2}\right\} \mathrm{NN}\left(\mathrm{HBAr}_{2}\right)_{2} \mathrm{CPh}_{2}\right\}$ $\left(17 \_N_{\beta}\right)$. In a glovebox, to a solution of $\mathrm{Cp} * \mathrm{Ti}\left\{\mathrm{MeC}\left(\mathrm{N}^{\mathrm{i}} \mathrm{Pr}\right)_{2}\right\}-$ $\left(\mathrm{NNCPh}_{2}\right)(4,20 \mathrm{mg}, 0.036 \mathrm{mmol})$ in $\mathrm{C}_{7} \mathrm{D}_{8}(0.3 \mathrm{~mL})$ in an NMR tube equipped with a J. Young Teflon valve was added $\operatorname{HBAr}_{2}{ }_{2}(12.1$ $\mathrm{mg}, 0.036 \mathrm{mmol})$ in $\mathrm{C}_{7} \mathrm{D}_{8}(0.3 \mathrm{~mL})$. The solution was immediately cooled to ca. $0{ }^{\circ} \mathrm{C}$ and transferred to the precooled (internal temperature ca. $0{ }^{\circ} \mathrm{C}$ ) probe of an NMR instrument. The NMR spectra showed quantitative conversion to $17 \mathbf{N}_{\beta}$ which was characterized in situ.

${ }^{1} \mathrm{H}$ NMR $\left(\mathrm{C}_{7} \mathrm{D}_{8}, 400.0 \mathrm{MHz}, 273 \mathrm{~K}\right): \delta 7.54\left(4 \mathrm{H}, \mathrm{dd},{ }^{3} J=6.6 \mathrm{~Hz}\right.$ $\left.o-\mathrm{C}_{6} \underline{\mathrm{H}}_{5}\right), 6.94\left(4 \mathrm{H}, \mathrm{m}, m-\mathrm{C}_{6} \underline{\mathrm{H}}_{5}\right), 6.71\left(2 \mathrm{H}, \mathrm{m}, p-\mathrm{C}_{6} \underline{\mathrm{H}}_{5}\right), 3.05(2 \mathrm{H}$, app. sept., $\left.{ }^{3} J=6.3 \mathrm{~Hz}, \mathrm{NC} \underline{\mathrm{HMeMe}}\right), 1.89\left(15 \mathrm{H}, \mathrm{s}, \mathrm{C}_{5} \mathrm{Me}_{5}\right), 1.70(3 \mathrm{H}$, $\left.\mathrm{s}, \mathrm{MeCN}_{2}\right), 0.86\left(6 \mathrm{H}, \mathrm{d},{ }^{3} \mathrm{~J}=6.3 \mathrm{~Hz}, \mathrm{NCHMeMe}\right), 0.75\left(6 \mathrm{H}, \mathrm{d},{ }^{3} \mathrm{~J}=\right.$ $6.3 \mathrm{~Hz}, \mathrm{NCHMeMe}) .{ }^{13} \mathrm{C}\left\{{ }^{1} \mathrm{H}\right\} \mathrm{NMR}\left(\mathrm{C}_{7} \mathrm{D}_{8}, 100.0 \mathrm{MHz}, 273 \mathrm{~K}\right): \delta$ $164.5\left(\mathrm{MeCN}_{2}\right), 137.1\left(i-\underline{\mathrm{C}}_{6} \mathrm{H}_{5}\right), 128.7\left(o-\underline{\mathrm{C}}_{6} \mathrm{H}_{5}\right), 126.6\left(p-\underline{\mathrm{C}}_{6} \mathrm{H}_{5}\right)$, $124.6\left(m-\underline{C}_{6} \mathrm{H}_{5}\right), 123.1 \quad\left(\underline{\mathrm{C}}_{5} \mathrm{Me}_{5}\right), 49.4$ (NCHMeMe), $25.9-25.4$ (overlapping NCHMeMe and NCHMeMe), $12.1\left(\mathrm{C}_{5} \mathrm{Me}_{5}\right),{ }^{11} \mathrm{~B}\left\{{ }^{1} \mathrm{H}\right\}$ $\left(\mathrm{C}_{7} \mathrm{D}_{8}, 128.4 \mathrm{MHz}, 293 \mathrm{~K}\right) \mathrm{NMR}-8.5(\mathrm{~s}) \mathrm{ppm}$. IR ( $\mathrm{NaCl}$ cell, toluene, $\left.\nu(\mathrm{B}-\mathrm{H}), \mathrm{cm}^{-1}\right): 2591(\mathrm{~s})$.

$C p * T i\left\{\mathrm{MeC}\left(\mathrm{N}^{\mathrm{P} P r}\right)_{2}\right\}\left\{\mathrm{N}\left(\mathrm{HBAr}_{2}{ }_{2}\right) \mathrm{NCPh} \mathrm{h}_{2}\right\}\left(17 \mathrm{~N}_{\alpha}\right)$. To a stirred solution of $\mathrm{Cp} * \mathrm{Ti}\left\{\mathrm{MeC}\left(\mathrm{N}^{\mathrm{i} P r}\right)_{2}\right\}\left(\mathrm{NNCPh}_{2}\right)(4,0.338 \mathrm{~g}, 0.652 \mathrm{mmol})$ in benzene $(10 \mathrm{~mL})$ was added $\mathrm{HBAr}^{\mathrm{F}}{ }_{2}(0.080 \mathrm{~g}, 0.652 \mathrm{mmol})$ at RT. The solution changed color immediately from dark brown to red. After stirring for $12 \mathrm{~h}$ at $\mathrm{RT}$, compound $\mathrm{Cp} * \mathrm{Ti}\{\mathrm{MeC}$ $\left(\mathrm{N}^{\mathrm{i}} \mathrm{Pr}\right)_{2}\left\{\mathrm{NBHAr}_{2}^{\mathrm{F}} \mathrm{NCPh}_{2}\right\} \quad\left(17 \mathrm{~N}_{\boldsymbol{\alpha}}\right)$ was isolated, volatiles were removed under reduced pressure and the product was washed with cold pentane and dried in vacuo, to yield an orange oil. Yield: $0.346 \mathrm{~g}$ (62\%).

${ }^{1} \mathrm{H}$ NMR $\left(\mathrm{C}_{6} \mathrm{D}_{6}, 400.0 \mathrm{MHz}, 298 \mathrm{~K}\right): \delta 7.09\left(4 \mathrm{H}, \mathrm{dd},{ }^{3} J=6.5 \mathrm{~Hz}\right.$, $\left.o-\mathrm{C}_{6} \mathrm{H}_{5}\right), 6.99\left(4 \mathrm{H}, \mathrm{m}, m-\mathrm{C}_{6} \mathrm{H}_{5}\right), 6.89\left(2 \mathrm{H}, \mathrm{m}, p-\mathrm{C}_{6} \mathrm{H}_{5}\right), 3.14(2 \mathrm{H}$ app. sept., $\left.{ }^{3} J=6.5 \mathrm{~Hz}, \mathrm{NC} \underline{\mathrm{HMeMe}}\right), 1.71\left(15 \mathrm{H}, \mathrm{s}, \mathrm{C}_{5} \mathrm{Me}_{5}\right), 1.57(3 \mathrm{H}$, $\left.\mathrm{s}, \mathrm{MeCN}_{2}\right), 1.04\left(6 \mathrm{H}, \mathrm{d},{ }^{3} \mathrm{~J}=6.5 \mathrm{~Hz}, \mathrm{NCHMeMe}\right), 0.99\left(6 \mathrm{H}, \mathrm{d},{ }^{3} \mathrm{~J}=\right.$ $6.5 \mathrm{~Hz}, \mathrm{NCHMeMe}) .{ }^{13} \mathrm{C}\left\{{ }^{1} \mathrm{H}\right\}$ NMR $\left(\mathrm{C}_{6} \mathrm{D}_{6}, 100.0 \mathrm{MHz}, 298 \mathrm{~K}\right): \delta$ $168.8\left(\mathrm{MeCN}_{2}\right), 145.7\left(3,5-\underline{\mathrm{C}}_{6} \mathrm{~F}_{5}\right), 141.8\left(4-\mathrm{C}_{6} \mathrm{~F}_{5}\right), 137.6\left(2,6-\mathrm{C}_{6} \mathrm{~F}_{5}\right)$, $129.8\left(i-\underline{C}_{6} \mathrm{H}_{5}\right), 129.5\left(o-\underline{C}_{6} \mathrm{H}_{5}\right), 126.6\left(p-\underline{C}_{6} \mathrm{H}_{5}\right), 124.6\left(m-\underline{C}_{6} \mathrm{H}_{5}\right)$, $121.4\left(\mathrm{C}_{5} \mathrm{Me}_{5}\right), 49.2$ (NCHMeMe), 23.9 (NCHMeMe), 24.3 (NCHMeMe), $16.4(\underline{\mathrm{MeCN}}), 11.2\left(\mathrm{C}_{5} \mathrm{Me}_{5}\right) .{ }^{11} \mathrm{~B}\left\{{ }^{1} \mathrm{H}\right\} \mathrm{NMR}\left(\mathrm{C}_{6} \mathrm{D}_{6}\right.$, $128.4 \mathrm{MHz}, 298 \mathrm{~K}): \delta-9.7 \mathrm{ppm} .{ }^{19} \mathrm{~F}\left\{{ }^{1} \mathrm{H}\right\} \mathrm{NMR}-130.7$ (2 F, 2,6$\left.\mathrm{C}_{6} \mathrm{~F}_{5}\right),-162.0\left(1 \mathrm{~F}, 4-\mathrm{C}_{6} \mathrm{~F}_{5}\right),-166.1\left(2 \mathrm{~F}, 3,5-\mathrm{C}_{6} \mathrm{E}_{5}\right)$. IR ( $\mathrm{NaCl}$ cell, toluene, $\left.\mathrm{cm}^{-1}\right): 1945(\mathrm{~s}, \nu(\mathrm{B}-\mathrm{H})), 1795,1803(\mathrm{w}), 1640(\mathrm{~s}) 1509(\mathrm{~s})$, $1321(\mathrm{~m}), 1086(\mathrm{~m}), 892(\mathrm{~m}), 766(\mathrm{~m}), 697(\mathrm{~s}), 621(\mathrm{~m})$. Anal. found (calcd. for $\mathrm{C}_{43} \mathrm{H}_{43} \mathrm{BF}_{10} \mathrm{~N}_{4} \mathrm{Ti}$ ): C, $59.74(59.62) ; \mathrm{H}, 5.01(5.01) ; \mathrm{N}, 6.48$ (6.54) \%. The NMR assignments were confirmed using HOESY $\left({ }^{1} \mathrm{H}-{ }^{19} \mathrm{~F}\right)$ spectroscopy.

NMR tube scale synthesis of Cp*Ti\{MeC(NiPr $\left.)_{2}\right\}\left\{N N\left(B A r_{2}{ }_{2}\right) C H P h_{2}\right\}$ (17). Over 4 days at RT, solutions of $\mathrm{Cp} * \mathrm{Ti}\left\{\mathrm{MeC}\left(\mathrm{N}^{\mathrm{i}} \mathrm{Pr}\right)_{2}\right\}\{\mathrm{N}$ $\left.\left(\mathrm{HBAr}_{2}{ }_{2}\right) \mathrm{NCPh}_{2}\right\} \quad\left(17 \mathbf{N}_{\alpha}\right)$ in toluene or benzene convert to $\mathrm{Cp}{ }^{*} \mathrm{Ti}\left\{\mathrm{MeC}\left(\mathrm{N}^{\mathrm{i} P r}\right)_{2}\right\}\left\{\mathrm{NN}\left(\mathrm{BAr}_{2}^{\mathrm{F}}\right) \mathrm{CHPh}_{2}\right\}$ (17) along with a number of unidentified side-products which could not be separated on the preparative scale. Compound 17 was therefore characterized by NMR spectroscopy in comparison with the crystallographically characterized analogues $\mathrm{Cp} * \mathrm{Ti}\left\{\mathrm{MeC}\left(\mathrm{N}^{\mathrm{i}} \mathrm{Pr}\right)_{2}\right\}\left\{\mathrm{NN}(\mathrm{Bpin}) \mathrm{CHPh}_{2}\right\}\left(\right.$ 16) and $\mathrm{Cp}^{*} \mathrm{Ti}-$ $\left\{\mathrm{MeC}(\mathrm{N} \mathrm{Pr})_{2}\right\}\left\{\mathrm{NN}\left(\mathrm{BC}_{8} \mathrm{H}_{14}\right) \mathrm{CHPh}_{2}\right\}$ (15), vide infra. In a glovebox, to a solution of $\mathrm{Cp} * \mathrm{Ti}\left\{\mathrm{MeC}\left(\mathrm{N}^{\mathrm{i}} \mathrm{Pr}\right)_{2}\right\}\left(\mathrm{NNCPh}_{2}\right)(4,20 \mathrm{mg}, 0.036$ $\mathrm{mmol})$ in $\mathrm{C}_{7} \mathrm{D}_{8}(0.3 \mathrm{~mL})$ in an NMR tube equipped with a J. Young Teflon valve was added $\mathrm{HBAr}_{2}{ }_{2}(12.1 \mathrm{mg}, 0.036 \mathrm{mmol})$ in $\mathrm{C}_{7} \mathrm{D}_{8}(0.3$ $\mathrm{mL}$ ). After 4 days at RT the NMR spectra showed the formation of $\mathbf{1 7}$ which was characterized by NMR spectroscopy.

${ }^{1} \mathrm{H}$ NMR $\left(\mathrm{C}_{6} \mathrm{D}_{6}, 400.0 \mathrm{MHz}, 298 \mathrm{~K}\right): \delta 7.31\left(4 \mathrm{H}, \mathrm{dd},{ }^{3} J=6.7 \mathrm{~Hz}\right.$, $\left.o-\mathrm{C}_{6} \underline{\mathrm{H}}_{5}\right), 7.03\left(4 \mathrm{H}, \mathrm{m}, m-\mathrm{C}_{6} \underline{\mathrm{H}}_{5}\right), 6.83\left(2 \mathrm{H}, \mathrm{m}, p-\mathrm{C}_{6} \underline{\mathrm{H}}_{5}\right), 6.15(1 \mathrm{H}, \mathrm{s}$, $\left.\mathrm{CHPh}_{2}\right), 3.24(2 \mathrm{H}$, broad, $\mathrm{NC} \underline{\mathrm{HMeMe}}), 1.85\left(15 \mathrm{H}, \mathrm{s}, \mathrm{C}_{5} \underline{\mathrm{Me}}_{5}\right), 1.71$ $\left(3 \mathrm{H}, \mathrm{s}, \mathrm{MeCN}_{2}\right), 0.79(6 \mathrm{H}, \mathrm{d}, \mathrm{NCHMeMe}), 0.66(6 \mathrm{H}, \mathrm{d}$, NCHMeMe $).{ }^{13} \mathrm{C}\left\{{ }^{1} \mathrm{H}\right\}$ NMR $\left(\mathrm{C}_{6} \mathrm{D}_{6}, 100.0 \mathrm{MHz}, 298 \mathrm{~K}\right): \delta 161.4$ $\left(\mathrm{Me} \underline{\mathrm{CN}}_{2}\right), 142.4\left(i-\underline{\mathrm{C}}_{6} \mathrm{H}_{5}\right), 129.4-127.4$ (overlapping $o-\underline{\mathrm{C}}_{6} \mathrm{H}_{5}, p-\underline{\mathrm{C}}_{6} \mathrm{H}_{5}$ and $\left.m-\underline{C}_{6} \mathrm{H}_{5}\right), 121.4\left(\underline{\mathrm{C}}_{5} \mathrm{Me}_{5}\right), 77.1\left(\mathrm{CHPh}_{2}\right), 48.5$ (NCHMeMe), 25.5 ( $\mathrm{NCHMeMe}), 24.5(\mathrm{NCHMeMe}), 12.5(\mathrm{MeCN}), 11.8\left(\mathrm{C}_{5} \underline{\mathrm{Me}}_{5}\right)$, ${ }^{11} \mathrm{~B}\left\{{ }^{1} \mathrm{H}\right\} \mathrm{NMR}\left(\mathrm{C}_{6} \mathrm{D}_{6}, 128.4 \mathrm{MHz}, 298 \mathrm{~K}\right) 33.5 \mathrm{ppm}$. 
$C p * T i\left\{M e C\left(N{ }^{i} P r\right)_{2}\right\}(H)\left\{N(B P i n) N M e_{2}\right\}$ (19). To a stirred solution of $\mathrm{Cp}^{*} \mathrm{Ti}\left\{\mathrm{MeC}\left(\mathrm{N}^{\mathrm{i} P r}\right)_{2}\right\}\left(\mathrm{NNMe}_{2}\right)(\mathbf{2}, 0.300 \mathrm{~g}, 0.785 \mathrm{mmol})$ in benzene $(10 \mathrm{~mL})$ was added HBpin $(0.112 \mathrm{~mL}, 0.785 \mathrm{mmol})$ at RT. An immediate color change from dark brown to dark green was observed. After $4 \mathrm{~h}$ the solution was then filtered, the volatiles removed under reduced pressure and the resultant green powder (19) washed with cold pentane $(3 \times 10 \mathrm{~mL})$ and dried in vacuo. Yield: $0.210 \mathrm{~g}(53 \%)$. Diffraction-quality crystals were grown from a concentrated benzene solution at room RT.

${ }^{1} \mathrm{H}$ NMR $\left(\mathrm{C}_{6} \mathrm{D}_{6}, 400.1 \mathrm{MHz}, 298 \mathrm{~K}\right): \delta 5.57(1 \mathrm{H}, \mathrm{s}, \mathrm{Ti}-\mathrm{H}), 3.54$ (1 H, app. sept., app. $\left.{ }^{3} J=6.4 \mathrm{~Hz}, \mathrm{CH}_{\mathrm{a}} \mathrm{MeMe}\right), 3.16(1 \mathrm{H}$, app. sept., app. $\left.{ }^{3} \mathrm{~J}=6.4 \mathrm{~Hz}, \mathrm{C}_{\mathrm{b}} \mathrm{MeMe}\right), 3.01(3 \mathrm{H}, \mathrm{s}, \mathrm{NNMeMe}), 2.81(3 \mathrm{H}, \mathrm{s}$, NNMeMe), $2.27\left(15 \mathrm{H}, \mathrm{s}, \mathrm{C}_{5} \mathrm{Me}_{5}\right), 1.67\left(3 \mathrm{H}, \mathrm{s}, \mathrm{MeCN}_{2}\right), 1.24(3 \mathrm{H}$, $\left.\mathrm{d},{ }^{3} \mathrm{~J}=6.5 \mathrm{~Hz}, \mathrm{NCH}_{\mathrm{a}} \mathrm{MeMe}\right), 1.15\left(3 \mathrm{H}, \mathrm{d},{ }^{3} \mathrm{~J}=6.5 \mathrm{~Hz}, \mathrm{NCH}_{\mathrm{a}} \mathrm{MeMe}\right)$, $1.11(6 \mathrm{H}, \mathrm{s}, \mathrm{BOCMe} 2), 1.10\left(3 \mathrm{H}, \mathrm{d},{ }^{3} J=6.5 \mathrm{~Hz}, \mathrm{NCH}_{\mathrm{b}} \mathrm{MeMe}\right), 1.09$ $\left(6 \mathrm{H}, \mathrm{s}, \mathrm{BOCMe}_{2}\right.$ of Bpin), $1.04\left(3 \mathrm{H}, \mathrm{d},{ }^{3} \mathrm{~J}=6.5 \mathrm{~Hz}, \mathrm{NCH}_{\mathrm{b}} \mathrm{MeMe}\right)$ ppm. ${ }^{13} \mathrm{C}\left\{{ }^{1} \mathrm{H}\right\}$ NMR $\left(\mathrm{C}_{6} \mathrm{D}_{6}, 100.6 \mathrm{MHz}, 298 \mathrm{~K}\right): \delta 172.5\left(\mathrm{MeCN}_{2}\right)$, $\left.120.1\left(\underline{C}_{5} \mathrm{Me}_{5}\right), 81.5(\mathrm{BOCMe})_{2}\right), 59.9$ (NNMeMe), 49.8 (NNMeMe), $48.8\left(\mathrm{NC}_{\mathrm{a}} \mathrm{MeMe}\right), 47.8\left(\mathrm{NC}_{\mathrm{b}} \mathrm{MeMe}\right), 27.4\left(\mathrm{NCH}_{\mathrm{b}} \mathrm{MeMe}\right), 26.8$ $\left(\mathrm{NCH}_{\mathrm{a}} \mathrm{MeMe}\right), 25.7 \quad\left(\mathrm{NCH}_{\mathrm{a}} \mathrm{MeMe}\right), \quad 24.9 \quad\left(\mathrm{BOCMe}_{2}\right) 24.7$ $\left(\mathrm{NCH}_{\mathrm{b}} \mathrm{MeMe}\right), 13.9\left(\mathrm{C}_{5} \mathrm{Me}_{5}\right), 12.7\left(\mathrm{MeCN}_{2}\right)$ ppm. ${ }^{11} \mathrm{~B}\left\{{ }^{1} \mathrm{H}\right\} \mathrm{NMR}$ $\left(\mathrm{C}_{6} \mathrm{D}_{6}, 128.4 \mathrm{MHz}, 298 \mathrm{~K}\right): \delta 23.7$ (s) ppm. IR ( $\mathrm{NaCl}$ plates, Nujol mull, $\mathrm{cm}^{-1}$ ): $1504(\mathrm{~s}, \nu(\mathrm{Ti}-\mathrm{H})), 1336(\mathrm{w}), 1261(\mathrm{~m}), 1201$ (s) 1147 (s), $1107(\mathrm{~m}), 1020(\mathrm{~m}), 967(\mathrm{~m}), 858(\mathrm{~m}), 793(\mathrm{~s}), 664(\mathrm{~m})$. EI-MS: $m / z=510[M]^{+}(2 \%)$. Anal. found (calcd. for $\mathrm{C}_{26} \mathrm{H}_{51} \mathrm{BN}_{4} \mathrm{O}_{2} \mathrm{Ti}$ ): $\mathrm{C}$, 61.18 (61.00); H, 10.07 (10.18); N, 10.98 (10.73)\%

$C p * T i\left\{M e C\left(N^{\prime} P_{2}\right)_{2}\right\}\left\{N\left(N_{2} e_{2}\right) H_{B A r}{ }_{2}\right\}$ (20). To a stirred solution of $\mathrm{Cp}{ }^{*} \mathrm{Ti}\left\{\mathrm{MeC}\left(\mathrm{N}^{\mathrm{i} P r}\right)_{2}\right\}\left(\mathrm{NNMe}_{2}\right)(2,0.300 \mathrm{~g}, 0.750 \mathrm{mmol})$ in benzene $(10 \mathrm{~mL})$ was added $\operatorname{HBAr}_{2}{ }_{2}(0.260 \mathrm{~g}, 0.750 \mathrm{mmol})$ at RT. An immediate color change from dark brown to dark red was observed. After $2 \mathrm{~h}$ the solution was then filtered; volatiles were removed under reduced pressure to afford a red oil which could not be crystallized. This was washed with cold pentane $(3 \times 10 \mathrm{~mL})$ and dried in vacuo. Yield: $0.367 \mathrm{~g}(80 \%)$.

${ }^{1} \mathrm{H}$ NMR $\left(\mathrm{C}_{6} \mathrm{D}_{6}, 400.0 \mathrm{MHz}, 298 \mathrm{~K}\right): \delta 3.31\left(2 \mathrm{H}\right.$, app. sept., ${ }^{3} \mathrm{~J}=$ $6.5 \mathrm{~Hz}, \mathrm{NC} \underline{\mathrm{HMe}_{2}}$ ), $2.75\left(6 \mathrm{H}, \mathrm{s}, \mathrm{NNMe}_{2}\right), 1.85\left(15 \mathrm{H}, \mathrm{s}, \mathrm{C}_{5} \underline{\mathrm{Me}}_{5}\right), 1.63$ $\left(3 \mathrm{H}, \mathrm{s}, \underline{\mathrm{MeCN}_{2}}\right), 0.89\left(6 \mathrm{H}, \mathrm{d},{ }^{3} J=6.5 \mathrm{~Hz}, \mathrm{NCHMeMe}\right), 0.81(6 \mathrm{H}$, d, $\left.{ }^{3} \mathrm{~J}=6.5 \mathrm{~Hz}, \mathrm{NCHMeMe}\right) .{ }^{13} \mathrm{C}\left\{{ }^{1} \mathrm{H}\right\} \mathrm{NMR}\left(\mathrm{C}_{6} \mathrm{D}_{6}, 100 \mathrm{MHz}, 293 \mathrm{~K}\right)$ : $\delta 161.9\left(\mathrm{MeCN}_{2}\right), 149.1$ (br d, $\left.{ }^{1} J=236.4 \mathrm{~Hz}, o-\underline{C}_{6} \mathrm{~F}_{5}\right), 140.5$ (overlapping br. d, $p-\underline{C}_{6} \mathrm{~F}_{5}$ and $m-\underline{\mathrm{C}}_{6} \mathrm{~F}_{5}$ ), 132.5 (br, $i-\underline{\mathrm{C}}_{6} \mathrm{~F}_{5}$ ), 120.2 $\left(\mathrm{C}_{5} \mathrm{Me}_{5}\right), 55.4\left(\mathrm{NNMe}_{2}\right), 49.1\left(\mathrm{NCHMe}_{2}\right), 26.3$ (NCHMeMe), 24.3 ( NCHMe $\underline{\mathrm{Me}}), 13.9\left(\mathrm{C}_{5} \underline{\mathrm{Me}}_{5}\right), 12.7\left(\underline{\mathrm{MeCN}}_{2}\right){ }^{11} \mathrm{~B}\left\{{ }^{1} \mathrm{H}\right\} \mathrm{NMR}\left(\mathrm{C}_{6} \mathrm{D}_{6}\right.$, $128.4 \mathrm{MHz}, 293 \mathrm{~K}):-6.8 \mathrm{ppm} .{ }^{19} \mathrm{~F}\left\{{ }^{1} \mathrm{H}\right\}$ NMR $(470.1 \mathrm{MHz}, 298 \mathrm{~K})$ : $-128.4\left(o-\mathrm{C}_{6} \underline{\mathrm{F}}_{5}\right),-158.7\left(m-\mathrm{C}_{6} \underline{\mathrm{F}}_{5}\right),-164.2\left(p-\mathrm{C}_{6} \underline{\mathrm{E}}_{5}\right)$. IR $(\mathrm{NaCl}$ plates, Nujol mull, $\left.\mathrm{cm}^{-1}\right): 2185(\mathrm{w}), 1990(\mathrm{~s}, v(\mathrm{~B}-\mathrm{H})), 1857(\mathrm{~m})$, $1802(\mathrm{~m}), 1648(\mathrm{~s}) 1264(\mathrm{w}), 1120(\mathrm{~m})$. Anal. found (calcd. for $\left.\mathrm{C}_{32} \mathrm{H}_{40} \mathrm{BF}_{10} \mathrm{~N}_{4} \mathrm{Ti}\right)$ : C, 52.39 (52.70); $\mathrm{H}, 5.30$ (5.53); N, 7.49 (7.68)\%. $C p * T i\left\{M e C\left(N{ }^{i} P r\right)_{2}\right\}\left(N B C_{8} H_{14}\right)$ (21). To a stirred solution of $\mathrm{Cp}^{*} \mathrm{Ti}-$ $\left\{\mathrm{MeC}\left(\mathrm{N}^{\mathrm{i} P r}\right)_{2}\right\}\left(\mathrm{NNMe}_{2}\right)(2,0.338 \mathrm{~g}, 0.884 \mathrm{mmol})$ in benzene (10 $\mathrm{mL})$ was added 9-BBN $(0.216 \mathrm{~g}, 0.884 \mathrm{mmol})$ all at RT. The solution was left to stir at RT for $12 \mathrm{~h}$, filtered and volatiles removed under reduced pressure to afford 21 and $\mathrm{Me}_{2} \mathrm{NBC}_{8} \mathrm{H}_{14}$ (characterized by comparison with the literature NMR data ${ }^{30 a}$ ) quantitatively in a $1: 1$ ratio as a sticky brown oil that was washed with pentane $(2 \times 10 \mathrm{~mL})$ to remove some of the $\mathrm{Me}_{2} \mathrm{NBC}_{8} \mathrm{H}_{14}$. The remaining aminoborane was separated by sublimation $\left(85-90^{\circ} \mathrm{C}, 2 \times 10^{-5} \mathrm{mbar}, 2 \mathrm{~h}\right)$ onto a dry ice/acetone coldfinger leaving 21 as a green powder. Yield: $0.150 \mathrm{~g}$ (37\%) Diffraction-quality crystals were grown from a concentrated hexane solution at $-30{ }^{\circ} \mathrm{C}$.

${ }^{1} \mathrm{H}$ NMR $\left(\mathrm{C}_{6} \mathrm{D}_{6}, 400.1 \mathrm{MHz}, 298 \mathrm{~K}\right): \delta 3.53$ (2 H, app. sept., app. ${ }^{3} J$ $\left.=6.5 \mathrm{~Hz}, \mathrm{CHMe}_{2}\right), 2.15\left(15 \mathrm{H}, \mathrm{s}, \mathrm{C}_{5} \mathrm{Me}_{5}\right), 1.65\left(3 \mathrm{H}, \mathrm{s}, \mathrm{MeCN}_{2}\right)$, $2.30-1.0(14 \mathrm{H}$, overlapping $3 \mathrm{~m}, \mathrm{BCH}, \mathrm{BCCH}$ and $\mathrm{BCCCH}), 1.00$ (6 $\left.\mathrm{H}, \mathrm{d},{ }^{3} \mathrm{~J}=6.5 \mathrm{~Hz}, \mathrm{CHMe}{ }_{2}\right), 0.91\left(6 \mathrm{H}, \mathrm{d},{ }^{3} J=6.5 \mathrm{~Hz}, \mathrm{CHMe}_{2}\right) \mathrm{ppm}$. ${ }^{13} \mathrm{C}\left\{{ }^{1} \mathrm{H}\right\}$ NMR $\left(\mathrm{C}_{6} \mathrm{D}_{6}, 100.6 \mathrm{MHz}, 298 \mathrm{~K}\right): \delta 167.2\left(\mathrm{MeCN}_{2}\right), 121.96$ $\left.\left(\underline{\mathrm{C}}_{5} \mathrm{Me}_{5}\right), 49.4(\underline{\mathrm{CHMe}})_{2}\right), 34.7(\mathrm{BC} \underline{\mathrm{CH}}), 26.1\left(\mathrm{CHMe}_{2}\right), 24.7$ $(\mathrm{CHMe} 2), 24.4$ (BCCㄷH), $12.3(\mathrm{BC} H), 13.0\left(\mathrm{C}_{5} \underline{\mathrm{Me}}_{5}\right), 11.6$ $\left(\mathrm{MeCN}_{2}\right)$ ppm. ${ }^{11} \mathrm{~B}$ NMR $\left(\mathrm{C}_{6} \mathrm{D}_{6}, 128.4 \mathrm{MHz}, 298 \mathrm{~K}\right): 52.8(\mathrm{~s})$ ppm. IR ( NaCl plates, Nujol mull, cm ${ }^{-1}$ ): 1601 (w), 1337 (w), 1313 (w), 1280 (s), 1212 (w), 1093 (s), 1018 (s), 800 (s). EI-MS: m/z =
$459[M]^{+}(2 \%)$. Anal. found (calcd. for $\left.\mathrm{C}_{26} \mathrm{H}_{46} \mathrm{BN}_{3} \mathrm{Ti}\right)$ : C, 67.98 (67.95); H, 10.09 (9.84); N, 9.15 (8.82)\%.

$\mathrm{Cp} * \mathrm{Ti}\left\{\mathrm{MeC}\left(\mathrm{N}^{i} \mathrm{Pr}\right)_{2}\right\}\left(\mathrm{NBC}_{8} \mathrm{H}_{14}\right)$ (21) from Cp*Ti\{MeC(NiPr$\left.)_{2}\right\}\left(\mathrm{NNPh}_{2}\right)$ (18). To a stirred solution of $\mathrm{Cp} * \mathrm{Ti}\left\{\mathrm{MeC}\left(\mathrm{N}^{\mathrm{i}} \mathrm{Pr}\right)_{2}\right\}\left(\mathrm{NNPh}_{2}\right) \quad$ (18, $0.448 \mathrm{~g}, 0.884 \mathrm{mmol})$ in benzene $(10 \mathrm{~mL})$ was added 9-BBN dimer $(0.216 \mathrm{~g}, 0.884 \mathrm{mmol})$ all at RT. The solution was left to stir at RT for $12 \mathrm{~h}$ at $60^{\circ} \mathrm{C}$, filtered and volatiles removed under reduced pressure to afford 21 and $\mathrm{Ph}_{2} \mathrm{NBC}_{8} \mathrm{H}_{14}$ (characterized by comparison with the literature NMR data ${ }^{30 b}$ ) quantitatively in a 1:1 ratio as a sticky brown oil, which could not be separated. The mixture was fully characterized on the NMR scale.

NMR tube scale synthesis of $C p * T i\left\{M e C\left(N^{i} P r\right)_{2}\right\}(H)\left\{N\left(B C_{8} H_{14}\right)-\right.$ $\left.\mathrm{NMe}_{2}\right\}$ (21_int). To a solution of $\mathrm{Cp} * \mathrm{Ti}\left\{\mathrm{MeC}\left(\mathrm{N}^{\mathrm{i}} \mathrm{Pr}\right)_{2}\right\}\left(\mathrm{NNMe}_{2}\right)$ (2, $0.020 \mathrm{mg}, 0.053 \mathrm{mmol})$ in $\mathrm{C}_{6} \mathrm{D}_{6}(0.3 \mathrm{~mL})$ in an NMR tube equipped with a J. Young Teflon valve was added 9-BBN $(0.128 \mathrm{mg}, 0.054$ $\mathrm{mmol})$ in $\mathrm{C}_{7} \mathrm{D}_{8}(0.3 \mathrm{~mL})$. The reaction was monitored by ${ }^{1} \mathrm{H}$ and ${ }^{11} \mathrm{~B}$ NMR spectroscopy. After $1 \mathrm{~h}$ at $0{ }^{\circ} \mathrm{C}$, the ${ }^{1} \mathrm{H}$ NMR spectrum showed complete conversion to 21 int and unreacted 9-BBN.

${ }^{1} \mathrm{H}$ NMR $\left(\mathrm{C}_{6} \mathrm{D}_{6}, 400.1 \overline{\mathrm{M}} \mathrm{Hz}, 298 \mathrm{~K}\right): \delta 6.30(1 \mathrm{H}, \mathrm{s}, \mathrm{Ti}-\mathrm{H}), 3.51$ (1 H, app. sept., app. $\left.{ }^{3} J=6.5 \mathrm{~Hz}, \mathrm{CH}_{\mathrm{a}} \mathrm{MeMe}\right), 3.34(2 \mathrm{H}$, app. sept., app. ${ }^{3} \mathrm{~J}=6.5 \mathrm{~Hz}, \underline{\mathrm{C}}_{\mathrm{b}} \mathrm{MeMe}$ ), 2.75 (3 H, broad s, NNMeMe), 2.65 (3 $\mathrm{H}$, broad s, NNMe $\underline{\underline{M e}}) 2.23\left(15 \mathrm{H}, \mathrm{s}, \mathrm{C}_{5} \underline{\mathrm{Me}}_{5}\right), 1.81\left(3 \mathrm{H}, \mathrm{s}, \underline{\mathrm{MeCN}_{2}}\right)$, 2.30-1.0 (14 H, overlapping 3m, BCㅌ, $\mathrm{BCC} \underline{\mathrm{H}}$ and $\mathrm{BCCC} \underline{\mathrm{H}}), 1.23$ (6 $\left.\mathrm{H}, \mathrm{d},{ }^{3} \mathrm{~J}=6.5 \mathrm{~Hz}, \mathrm{CHMe} 2\right), 1.17\left(6 \mathrm{H}, \mathrm{d},{ }^{3} \mathrm{~J}=6.5 \mathrm{~Hz}, \mathrm{CHMe}_{2}\right) \mathrm{ppm}$. ${ }^{13} \mathrm{C}\left\{{ }^{1} \mathrm{H}\right\} \mathrm{NMR}\left(\mathrm{C}_{6} \mathrm{D}_{6}, 100.6 \mathrm{MHz}, 298 \mathrm{~K}\right): \delta 160.9\left(\mathrm{MeCN}_{2}\right), 122.6$ $\left(\underline{\mathrm{C}}_{5} \mathrm{Me}_{5}\right), 56.7$ (NNMeMe), 51.5 (NNMeMe), $48.1\left(\mathrm{NCH}_{\mathrm{a}} \mathrm{MeMe}\right)$, $47.6\left(\mathrm{NCH}_{\mathrm{b}} \mathrm{MeMe}\right), 33.5(\mathrm{BC} \underline{\mathrm{CH}}), 25.9-24.4$ (overlapping $\mathrm{NCH}_{a} \underline{\mathrm{MeMe}}, \mathrm{NCH}_{\mathrm{a}} \mathrm{Me} \underline{\mathrm{Me}}, \mathrm{NCH}_{b} \underline{\mathrm{MeMe}}$ and $\left.\mathrm{NCH}_{\mathrm{b}} \mathrm{MeMe}\right), 24.4$ (BCC $\underline{\mathrm{CH}}), 14.3(\mathrm{~B} \underline{\mathrm{CH}}), 13.4\left(\mathrm{C}_{5} \underline{\mathrm{Me}}_{5}\right), 11.1\left(\underline{\mathrm{MeCN}}_{2}\right) \mathrm{ppm} .{ }^{11} \mathrm{~B}\left\{{ }^{1} \mathrm{H}\right\}$ NMR $\left(\mathrm{C}_{6} \mathrm{D}_{6}, 128.4 \mathrm{MHz}, 298 \mathrm{~K}\right): 28.1$ (s) ppm.

$\mathrm{X}$-ray data collection and processing procedures. Crystals were mounted on glass fibers using perfluoropolyether oil and cooled rapidly in a stream of cold $\mathrm{N}_{2}$ using an Oxford Cryosystems Cryostream unit. Diffraction data were measured using either an EnrafNonius KappaCCD or Agilent Technologies Supernova diffractometer using $\mathrm{Mo} \mathrm{K} \alpha$ or $\mathrm{Cu} \mathrm{K} \alpha$ radiation, respectively. As appropriate, absorption and decay corrections were applied to the data and equivalent reflections merged. ${ }^{35}$ The structures were solved with SIR92 $^{36}$ or Superflip, ${ }^{37}$ and further refinements and all other crystallographic calculations were performed using the CRYSTALS program suite. ${ }^{38}$ The CIF files contain specific details for the refinements of the individual structures. The CCDC codes for the structures in this paper are CCDC 1407872, 1407873, and 15567431556746.

Computational Details. Geometry optimizations were performed with the Gaussian09 package (rev. D.01) ${ }^{39}$ at the B3PW91 level of hybrid density functional theory in the gas phase with the titanium atom represented by the relativistic effective core potential (RECP) from the Stuttgart group and the associated basis set, ${ }^{40}$ augmented by an $\mathrm{f}$ polarization function, ${ }^{41}$ and the remaining atoms represented by a def2-svp basis set. ${ }^{42}$ Dispersion was taken into account both at the optimization and single point stages using Grimme's $\mathrm{d} 3(\mathrm{bj})$ corrections $^{43}$ as implemented in Gaussian09. In addition, the solvent (benzene) influence was taken into consideration in the single point calculations on the gas-phase optimized geometry with SCRF calculations within the SMD model and a def2-qzvpp basis set for all atoms. Gibbs free energies and enthalpies were obtained by summing the SMD energy, the gas-phase Gibbs or enthalpy contribution at $298.15 \mathrm{~K}$ obtained from the geometry optimizations, and the $\mathrm{d} 3(\mathrm{bj})$ correction. The total SCF and other energies are given in Table S3. NMR chemical shifts were computed using the GIAO method $^{44}$ as implemented in Gaussian09 at the B3PW91 level. All atoms were described with the pcSseg-2 NMR basis sets of Jensen. ${ }^{45}$ The ${ }^{11} \mathrm{~B}$ NMR shifts are referenced with respect to the experimental value of $0.0 \mathrm{ppm}$ for $\mathrm{BF}_{3}\left(\mathrm{Et}_{2} \mathrm{O}\right)$. The Cartesian coordinates for the DFT structures are provided as Supporting Information. 


\section{ASSOCIATED CONTENT}

\section{S Supporting Information}

The Supporting Information is available free of charge on the ACS Publications website at DOI: 10.1021/acs.organomet.7b00477.

Remaining details of the DFT calculations (PDF)

Computed Cartesian coordinates of all of the DFT structures reported in this study (XYZ)

\section{Accession Codes}

CCDC 1407872, 1407873, and 1556743-1556746 contain the supplementary crystallographic data for this paper. These data can be obtained free of charge via www.ccdc.cam.ac.uk/ data request/cif, or by emailing data request@ccdc.cam.ac. uk, or by contacting The Cambridge Crystallographic Data Centre, 12 Union Road, Cambridge CB2 1EZ, UK; fax: +44 1223336033.

\section{AUTHOR INFORMATION}

\section{Corresponding Authors}

*E-mail: eric.clot@umontpellier.fr.

*E-mail: philip.mountford@chem.ox.ac.uk.

ORCID

Eric Clot: 0000-0001-8332-5545

Philip Mountford: 0000-0001-9869-9902

Notes

The authors declare no competing financial interest.

\section{ACKNOWLEDGMENTS}

This work was funded by the EPSRC (grant reference EP/ K503113/1 (LCS)), the University of Oxford Clarendon Fund (SM), and the University of Oxford SCG Innovation Fund. We thank the University of Oxford's Advanced Research Computing facility for access to supercomputer and other resources. The authors declare no competing financial interests.

\section{REFERENCES}

(1) (a) Wigley, D. E. Prog. Inorg. Chem. 1994, 42, 239-482. (b) Duncan, A. P.; Bergman, R. G. Chem. Rec. 2002, 2, 431-445. (c) Mountford, P. Chem. Commun. 1997, 2127-2134. (d) Gade, L. H.; Mountford, P. Coord. Chem. Rev. 2001, 216-217, 65-97. (e) Hazari, N.; Mountford, P. Acc. Chem. Res. 2005, 38, 839-849. (f) Bolton, P. D.; Mountford, P. Adv. Synth. Catal. 2005, 347, 355-366. (g) Fout, A. R.; Kilgore, U. J.; Mindiola, D. J. Chem. - Eur. J. 2007, 13, 9428-9440. (h) Odom, A. L. Dalton Trans. 2005, 225-233. (i) Schafer, L. L.; Lee, A. V. Eur. J. Inorg. Chem. 2007, 2007, 2245-2255. (j) Müller, T. E.; Hultzsch, K. C.; Yus, M.; Foubelo, F.; Tada, M. Chem. Rev. 2008, 108, 3795-3892. (k) Lorber, C. Coord. Chem. Rev. 2016, 308, 76-96.

(2) (a) Mindiola, D. J. Angew. Chem., Int. Ed. 2008, 47, 1557-1559.

(b) Dilworth, J. R. Coord. Chem. Rev. 2017, 330, 53-94.

(3) (a) Kool, L. B.; Rausch, M. D.; Alt, H. G.; Herberhold, M.; Hill, A. F.; Thewalt, U.; Wolf, B. J. Chem. Soc., Chem. Commun. 1986, 408409. (b) Polse, J. L.; Kaplan, A. W.; Andersen, R. A.; Bergman, R. G. J. Am. Chem. Soc. 1998, 120, 6316-6328. (c) Kaplan, A. W.; Polse, J. L.; Ball, G. E.; Andersen, R. A.; Bergman, R. G. J. Am. Chem. Soc. 1998, 120, 11649-11662. (d) Hanna, T. E.; Keresztes, I.; Lobkovsky, E.; Bernskoetter, W. H.; Chirik, P. J. Organometallics 2004, 23, 34483458. (e) Tiong, P. J.; Groom, L. R.; Clot, E.; Mountford, P. Chem. Eur. J. 2013, 19, 4198-4216.

(4) (a) Schwarz, A. D.; Nova, A.; Clot, E.; Mountford, P. Chem. Commun. 2011, 47, 4926-4928. (b) Schwarz, A. D.; Nova, A.; Clot, E.; Mountford, P. Inorg. Chem. 2011, 50, 12155-12171. (c) Groom, L. R.; Schwarz, A. D.; Nova, A.; Clot, E.; Mountford, P. Organometallics 2013, 32, 7520-7539.
(5) (a) Thompson, R.; Chen, C.-H.; Pink, M.; Wu, G.; Mindiola, D. J. J. Am. Chem. Soc. 2014, 136, 8197-8200. (b) Stevenson, L. C.; Mellino, S.; Clot, E.; Mountford, P. J. Am. Chem. Soc. 2015, 137, 10140-10143. (c) Grant, L. N.; Pinter, B.; Kurogi, T.; Carroll, M. E.; Wu, G.; Manor, B. C.; Carroll, P. J.; Mindiola, D. J. Chem. Sci. 2017, 8, $1209-1224$.

(6) (a) Walsh, P. J.; Carney, M. J.; Bergman, R. G. J. Am. Chem. Soc. 1991, 113, 6343-6345. (b) Herrmann, H.; Fillol, J. L.; Wadepohl, H.; Gade, L. H. Angew. Chem., Int. Ed. 2007, 46, 8426-8430. (c) Selby, J. D.; Manley, C. D.; Feliz, M.; Schwarz, A. D.; Clot, E.; Mountford, P. Chem. Commun. 2007, 4937-4939. (d) Schofield, A. D.; Nova, A.; Selby, J. D.; Schwarz, A. D.; Clot, E.; Mountford, P. Chem. - Eur. J. 2011, 17, 265-285. (e) Schofield, A. D.; Nova, A.; Selby, J. D.; Manley, C. D.; Schwarz, A. D.; Clot, E.; Mountford, P. J. Am. Chem. Soc. 2010, 132, 10484-10497. (f) Gehrmann, T.; Scholl, S. A.; Fillol, J. L.; Wadepohl, H.; Gade, L. H. Chem. - Eur. J. 2012, 18, 3925-3942. (g) Unruangsri, J.; Morgan, H.; Schwarz, A. D.; Schofield, A. D.; Mountford, P. Organometallics 2013, 32, 3091-3107.

(7) (a) Walsh, P. J.; Hollander, F. J.; Bergman, R. G. J. Am. Chem. Soc. 1988, 110, 8729-8731. (b) Cummins, C. C.; Baxter, S. M.; Wolczanski, P. T. J. Am. Chem. Soc. 1988, 110, 8731-8733.

(8) (a) Bennett, J. L.; Wolczanski, P. T. J. Am. Chem. Soc. 1994, 116, 2179-2180. (b) Schaller, C. P.; Bonanno, J. B.; Wolczanski, P. T. J. Am. Chem. Soc. 1994, 116, 4133-4134. (c) Schaller, C. P.; Cummins, C. C.; Wolczanski, P. T. J. Am. Chem. Soc. 1996, 118, 591-611. (d) Bennett, J. L.; Wolczanski, P. T. J. Am. Chem. Soc. 1997, 119, 10696-10719. (e) Hoyt, H. M.; Michael, F. E.; Bergman, R. G. J. Am. Chem. Soc. 2004, 126, 1018-1019. (f) Hoyt, H. M.; Bergman, R. G. Angew. Chem., Int. Ed. 2007, 46, 5580-5582. (g) Polse, J. L.; Andersen, R. A.; Bergman, R. G. J. Am. Chem. Soc. 1998, 120, 13405-13414. (h) Toomey, H. E.; Pun, D.; Veiros, L. F.; Chirik, P. J. Organometallics 2008, 27, 872-879.

(9) (a) Crevier, T. J.; Mayer, J. M. Angew. Chem., Int. Ed. 1998, 37, 1891-1893. (b) Parkin, G.; Bercaw, J. E. J. Am. Chem. Soc. 1989, 111, 391-393. (c) Gountchev, T. I.; Tilley, T. D. J. Am. Chem. Soc. 1997, 119, 12831-12841. (d) Sweeney, Z. K.; Polse, J. L.; Bergman, R. G.; Andersen, R. A. Organometallics 1999, 18, 5502-5510. (e) Chu, J.; Lu, E.; Chen, Y.; Leng, X. Organometallics 2013, 32, 1137-1140. (f) Chu, J.; Han, X.; Kefalidis, C. E.; Zhou, J.; Maron, L.; Leng, X.; Chen, Y. J. Am. Chem. Soc. 2014, 136, 10894-10897. (g) Thompson, R.; Tran, B. A.; Ghosh, S.; Chen, C.-H.; Pink, M.; Gao, X.; Carroll, P. J.; Baik, M.H.; Mindiola, D. J. Inorg. Chem. 2015, 54, 3068-3077.

(10) (a) Tiong, P. J.; Nova, A.; Schwarz, A. D.; Selby, J. D.; Clot, E.; Mountford, P. Dalton Trans. 2012, 41, 2277-2288. (b) Tiong, P. J.; Nova, A.; Clot, E.; Mountford, P. Chem. Commun. 2011, 47, 31473149.

(11) Stevenson, L. C. D. Phil. Thesis, University of Oxford, 2015.

(12) Parks, D. J.; Piers, W. E.; Yap, G. P. A. Organometallics 1998, 17, $5492-5503$

(13) Zhou, E.; Ren, W.; Hou, G.; Zi, G.; Fang, D.-C.; Walter, M. D. Organometallics 2015, 34, 3637-3647.

(14) Jacobs, E. A.; Fuller, A.; Coles, S. J.; Jones, G. A.; Tizzard, G. J.; Wright, J. A.; Lancaster, S. J. Chem. - Eur. J. 2012, 18, 8647-8658.

(15) Schwier, J. R.; Brown, H. C. J. Org. Chem. 1993, 58, 1546-1552.

(16) Zhdanko, A.; Maier, M. E. Eur. J. Org. Chem. 2014, 2014, 34113422.

(17) Pelter, A.; Smith, K.; Brown, H. C. Borane Reagents; Academic Press: New York, 1988.

(18) Hadlington, T. J.; Abdalla, J. A. B.; Tirfoin, R.; Aldridge, S.; Jones, C. Chem. Commun. 2016, 52, 1717-1720.

(19) Wallis, C. J.; Dyer, H.; Vendier, L.; Alcaraz, G.; Sabo-Etienne, S. Angew. Chem., Int. Ed. 2012, 51, 3646-3648.

(20) Hermanek, S. Chem. Rev. 1992, 92, 325-362.

(21) Fletcher, D. A.; McMeeking, R. F.; Parkin, D. J. Chem. Inf. Comput. Sci. 1996, 36, 746-759 (The UK Chemical Database Service: CSD version 745.738, updated May 2017)..

(22) (a) Boyd, C. L.; Clot, E.; Guiducci, A. E.; Mountford, P. Organometallics 2005, 24, 2347-2367. (b) Boyd, C. L.; Guiducci, A. E.; Dubberley, S. R.; Tyrrell, B. R.; Mountford, P. J. Chem. Soc., Dalton 
Trans. 2002, 4175-4184. (c) Guiducci, A. E.; Boyd, C. L.; Clot, E.; Mountford, P. Dalton Trans. 2009, 5960-5979. (d) Guiducci, A. E.; Boyd, C. L.; Mountford, P. Organometallics 2006, 25, 1167-1187. (e) Guiducci, A. E.; Cowley, A. R.; Skinner, M. E. G.; Mountford, P. J. Chem. Soc., Dalton Trans. 2001, 1392-1934.

(23) Tiong, P. J.; Nova, A.; Groom, L. R.; Schwarz, A. D.; Selby, J. D.; Schofield, A. D.; Clot, E.; Mountford, P. Organometallics 2011, 30, $1182-1201$.

(24) (a) Li, Y.; Shi, Y.; Odom, A. L. J. Am. Chem. Soc. 2004, 126, 1794-1803. (b) Clulow, A. J.; Selby, J. D.; Cushion, M. G.; Schwarz, A. D.; Mountford, P. Inorg. Chem. 2008, 47, 12049-12062.

(25) Vale, M. G.; Schrock, R. R. Inorg. Chem. 1993, 32, 2767-2772.

(26) Dreher, A.; Mersmann, K.; Nather, C.; Ivanovic-Burmazovic, I.; van Eldik, R; Tuczek, F. Inorg. Chem. 2009, 48, 2078-2093.

(27) Stout, G. H.; Jensen, L. H. X-Ray Structure Determination, 2nd ed.; John Wiley \& Sons: Toronto, 1989.

(28) (a) Latham, I. A.; Leigh, G. J.; Huttner, G.; Jibril, I. J. Chem. Soc., Dalton Trans. 1986, 385-391. (b) Hemmer, R.; Thewalt, U.; Hughes, D. L.; Leigh, G. J.; Walker, D. G. J. Organomet. Chem. 1987, 323, C29C32. (c) Hughes, D. L.; Leigh, G. J.; Walker, D. G. J. Chem. Soc., Dalton Trans. 1989, 1413-1416. (d) Hughes, D. L.; Jimenez-Tenorio, M.; Leigh, G. J.; Walker, D. G. J. Chem. Soc., Dalton Trans. 1989, 2389-2395. (e) Goetze, B.; Knizek, J.; Noth, H.; Schnick, W. Eur. J. Inorg. Chem. 2000, 2000, 1849-1854. (f) Lehn, J.-S. M.; Hoffman, D. M. Inorg. Chim. Acta 2003, 345, 327-332. (g) Pietryga, J. M.; Jones, J. N.; Macdonald, C. L. B.; Moore, J. A.; Cowley, A. H. Polyhedron 2006, 25, 259-265. (h) Weitershaus, K.; Fillol, J. L.; Wadepohl, H.; Gade, L. H. Organometallics 2009, 28, 4747-4757. (i) Selby, J. D.; Feliz, M.; Schwarz, A. D.; Clot, E.; Mountford, P. Organometallics 2011, 30, 2295-2307.

(29) Janssen, T.; Severin, R.; Diekmann, M.; Friedemann, M.; Haase, D.; Saak, W.; Doye, S.; Beckhaus, R. Organometallics 2010, 29, 18061817.

(30) (a) Komorowski, L.; Meller, A.; Niedenzu, K. Inorg. Chem. 1990, 29, 538-541. (b) Barrett, A. G. M.; Crimmin, M. R.; Hill, M. S.; Hitchcock, P. B.; Procopiou, P. A. Organometallics 2007, 26, 40764079.

(31) (a) Danopoulos, A. A.; Redshaw, C.; Vaniche, A.; WIlkinson, G.; Hussain-Bates, B.; Hursthouse, M. B. Polyhedron 1993, 12, 10611071. (b) Weber, K.; Korn, K.; Schorm, A.; Kipke, J.; Lemke, M.; Khvorost, A.; Harms, K.; Sundermeyer, J. Z. Anorg. Allg. Chem. 2003, 629, 744-754. (c) Fryzuk, M. D.; MacKay, B. A.; Johnson, S. A.; Patrick, B. O. Angew. Chem., Int. Ed. 2002, 41, 3709-3712.

(32) Johnson, H. C.; Hooper, T. N.; Weller, A. S. Top. Organomet. Chem. 2015, 49, 153-220.

(33) Pangborn, A. B.; Giardello, M. A.; Grubbs, R. H.; Rosen, R. K.; Timmers, F. J. Organometallics 1996, 15, 1518-1520.

(34) Fuller, A.-M.; Hughes, D. L.; Lancaster, S. J.; White, C. M. Organometallics 2010, 29, 2194-2197.

(35) (a) Otwinowski, Z.; Minor, W. Processing of X-ray Diffraction Data Collected in Oscillation Mode; Academic press: New York, 1997. (b) CrysAlisPro; Agilent Technologies: Oxford, U.K., 2011.

(36) Altomare, A.; Cascarano, G.; Giacovazzo, G.; Guagliardi, A.; Burla, M. C.; Polidori, G.; Camalli, M. J. Appl. Crystallogr. 1994, 27, 435-435.

(37) Palatinus, L.; Chapuis, G. J. Appl. Crystallogr. 2007, 40, 786790.

(38) Betteridge, P. W.; Cooper, J. R.; Cooper, R. I.; Prout, K.; Watkin, D. J. J. Appl. Crystallogr. 2003, 36, 1487-1487.

(39) Frisch, M. J.; Trucks, G. W.; Schlegel, H. B.; Scuseria, G. E.; Robb, M. A.; Cheeseman, J. R.; Scalmani, G.; Barone, V.; Mennucci, B.; Petersson, G. A.; Nakatsuji, H.; Caricato, M.; Li, X.; Hratchian, H. P.; Izmaylov, A. F.; Bloino, J.; Zheng, G.; Sonnenberg, J. L.; Hada, M.; Ehara, M.; Toyota, K.; Fukuda, R.; Hasegawa, J.; Ishida, M.; Nakajima, T.; Honda, Y.; Kitao, O.; Nakai, H.; Vreven, T.; Montgomery, J. A., Jr.; Peralta, J. E.; Ogliaro, F.; Bearpark, M. J.; Heyd, J.; Brothers, E. N.; Kudin, K. N.; Staroverov, V. N.; Kobayashi, R.; Normand, J.; Raghavachari, K.; Rendell, A. P.; Burant, J. C.; Iyengar, S. S.; Tomasi, J.; Cossi, M.; Rega, N.; Millam, N. J.; Klene, M.; Knox, J. E.;
Cross, J. B.; Bakken, V.; Adamo, C.; Jaramillo, J.; Gomperts, R.; Stratmann, R. E.; Yazyev, O.; Austin, A. J.; Cammi, R.; Pomelli, C.; Ochterski, J. W.; Martin, R. L.; Morokuma, K.; Zakrzewski, V. G.; Voth, G. A.; Salvador, P.; Dannenberg, J. J.; Dapprich, S.; Daniels, A. D.; Farkas, Ö.; Foresman, J. B.; Ortiz, J. V.; Cioslowski, J.; Fox, D. J. Gaussian 09, Revision D.01; Gaussian, Inc.: Wallingford, CT, USA, 2009.

(40) Andrae, D.; Haussermann, U.; Dolg, M.; Stoll, H.; Preuss, H. Theor. Chim. Acta 1990, 77, 123-141.

(41) Ehlers, A. W.; Bohme, M.; Dapprich, S.; Gobbi, A.; Hollwarth, A.; Jonas, V.; Kohler, K. F.; Stegmann, R,; Veldkamp, A.; Frenking, G. Chem. Phys. Lett. 1993, 208, 111-114.

(42) Weigend, F.; Ahlrichs, R. Phys. Chem. Chem. Phys. 2005, 7, $3297-3305$

(43) Grimme, S.; Antony, J.; Ehrlich, S.; Krieg, H. J. Chem. Phys. 2010, 132, 154104-154119.

(44) (a) Lee, A. M.; Handy, N. C.; Colwell, S. M. J. Chem. Phys. 1995, 103, 10095-10109. (b) Ditchfield, R. J. J. Chem. Phys. 1972, 56, $5688-5691$.

(45) Jensen, F. J. Chem. Theory Comput. 2015, 11, 132-138. 